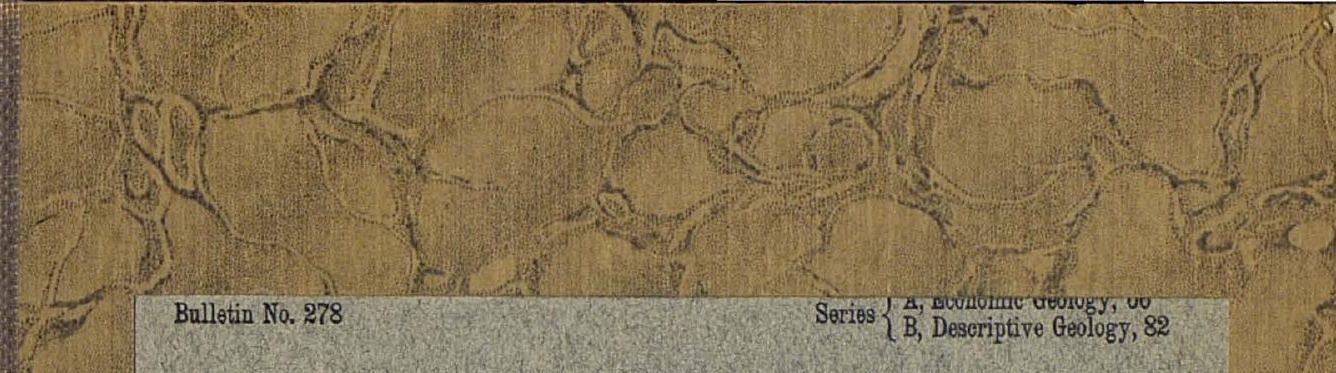

DEPARTMENT OF THE INTERIOR UNITED STATES GEOLOGICAL SURVEY CHARLES D. WALCOTT, DIAECTOR

GEOLOGY AND COAL RESOURCES OF THE CAPE LISBURNE REGTON, ALASKA

ARTHUR J. COLIIER 

DEPARTMENT OF THE INTERIOR

UNITED STATES GEOLOGICAL SURVEY

CHARLES D. WALCOTT, DIRECTOR

\title{
GEOLOGY AND COAL RESOURCES OF THE CAPE LISBURNE REGION, ALASKA
}

BY

\author{
ARTHUR J. COLLIER
}

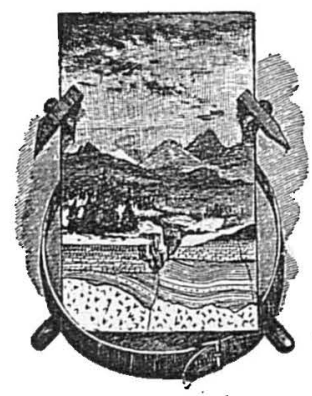

WASHINGTON

GOVWRNMENT PRINTING OFEICE

1906 



\section{GONTENTS.}

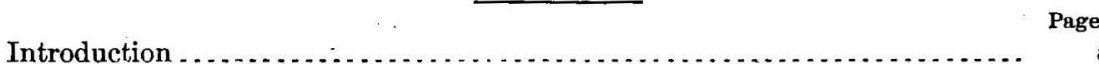

History and explorations . . . . . . . . . 6

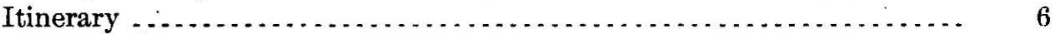

Acknowledgments............................................. 9

Geography.................................................. 9

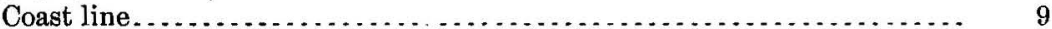

The Arctic Ocean . . . . . . . . .

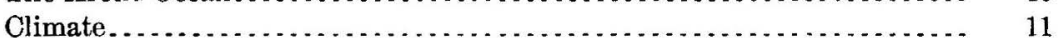

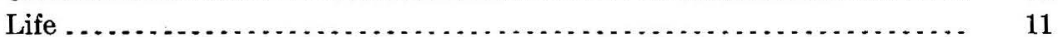

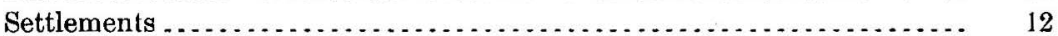

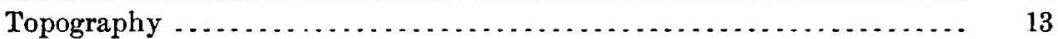

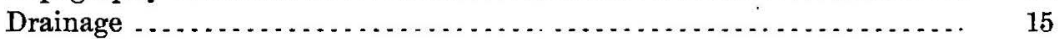

Routes of travel ............................................. 16

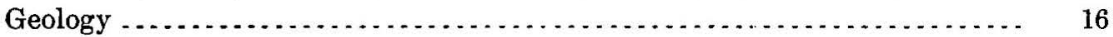

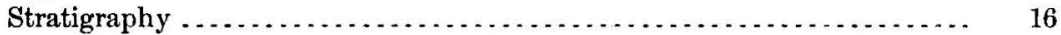

Paleozoic formations.................................... 17

Devonian rocks .................................... 17

Carboniferous rocks ............................... 18

Lower formation $\ldots \ldots \ldots \ldots \ldots \ldots \ldots \ldots \ldots \ldots \ldots \ldots, 18$

Middle formation .............................. 19

Lisburne formation.............................. 21

Report on fossil plants, by David IVhite................ $\quad 22$

Report on fossil invertebrates, by (i. H. Girty........... . 22

Other Carboniferous areas in Alaska ................... $\quad 26$

Mesozoic formations.................................... 27

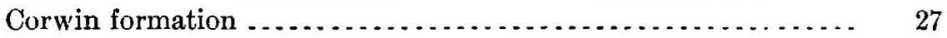

Report on Mesozoic fossil plants, by F. H. Knowiton .......... 29

Upper Mesozoic beds .................................. $\quad 30$

Quaternary deposits ..................................... 31

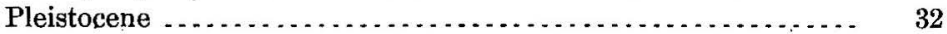

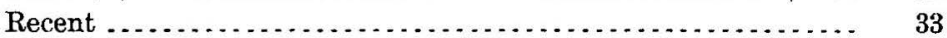

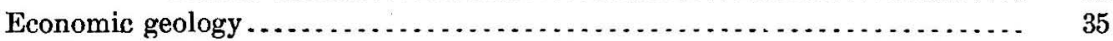

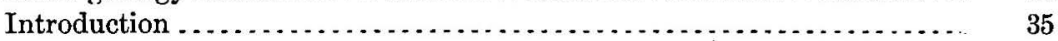

Mesozoic coal field .............................................. 36

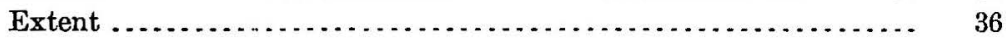

The coal beds ................................................. 37

Corwin group ........................................... 37

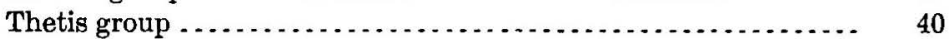

East of Cape Sabine................................. 41

Cape Beaufort ......................................... 41

Wainwright Inlet ........................................ 41

Inland extension ...................................... 42 
Economic geology-Continued. Page.

Paleozoic coal fields ............................................ 43

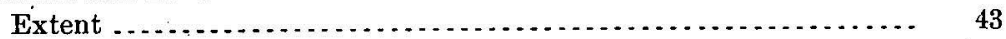

Localities in detail ......................................... 43

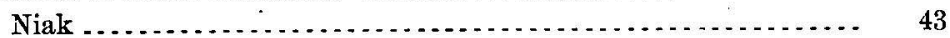

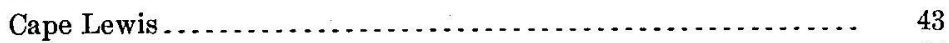

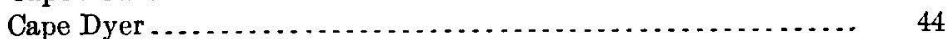

Kukpuk River............................................ 45

Cape Thompson ......................................... 45

Inland extension of Paleozoic coals........................ 45

Character of the Cape Lisburne coals .......................... 46

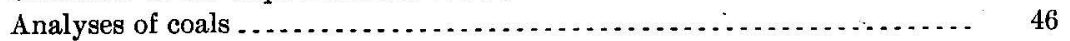

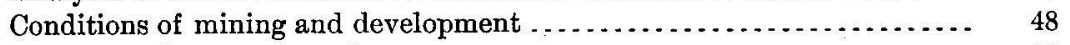

Summary of economic geology ............................... 49

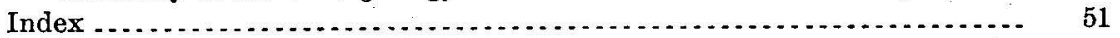

\section{L LUSTRA T I O N S.}

Plate I. Topographic and geologic map of Cape Lisburne region.............

II. $A$, U. S. revenue cutter Thetis in the edge of an ice floe; $B$, Cliffs west of Corwin Bluff .

III. $A$, Outcrops of limestone on north slope of mountain at Cape Lisburne; $B$, Whaling station at Jabbertown on Point Hope peninsula

IV. $A$, Agate Rock, Cape Thompson; $B$, Folded beds and thrust fault in upper member of Mesozoic series, 5 miles east of Cape Lisburne.

V. Paleozoic and Mesozoic plants from Cape Lisburne region, Alaska..

VI. Tertiary plants from Kenai (Eocene) formation of Alaska ..........

VII. Map of part of Corwin coal field ................................

VIII. Partly developed coal bed at Corwin Bluff.....................

IX. Columnar section of Corwin formation .......................

Fra. 1. Sketch of detail of jointing and cleavage in pre-Carboniferous rocks south of Cape Dyer.

2. Thrust fault at the contact of Carboniferous and pre-Carboniferous rocks south of Cape Dyer ...................................

3. Section of Carboniferous coal formation between Cape Dyer and the Ears.

4. Sketch showing stratigraphic relations of the Carboniferous formations south of Cape Lewis .

5. Sketch of thrust faults in Carboniferous rocks 6 miles north of Cape Lewis

6. Ground plan of outcrops 3 miles east of Cape Lisburne..............

7. Sketch of the section exposed in the cliffs at Cape Thompson.........

8. Section of irregular coal bed underlying the conglomerate at Corwin Bluff 


\title{
GEOLOGY AND COAL RESOURCES OF THE CAPE LISBURNE REGION, ALASKA. ${ }^{a}$
}

\author{
By Arthur J. Coliter. \\ INTRODUCTION.
}

Cape Lisburne is the bold headland which marks the northwestern extremity of a land mass projecting into the Arctic Ocean from the western coast of Alaska between latitudes $68^{\circ}$ and $69^{\circ}$. It lies 160 miles north of the Arctic Circle, 300 miles directly north of Nome, and is the only point in Alaska north of Bering Strait where hills above 1,000 feet in height approach the sea. This peninsula can be conveniently termed the Cape Lisburne region. Its general position is shown in Pl. I. In outline it roughly resembles a conventional hand, of which Cape Lisburne forms the knuckle and Point Hope, about 40 miles southwest of Cape Lisburne, the index finger, pointing west.

The only mineral resources of the. region that are known to be of commercial importance are the coal deposits, which are the subject of this report, though gold is reported on the headwaters of some of the rivers.

The coal fields are accessible only by sea, and in this way only from July to October, inclusive. There are no harbors or protection for seagoing vessels, but in calm weather, or when the winds are from the south, coal can be boated or lightered to ships anchored from 1 to 2 miles offshore.

The nearest protected harbor is Kotzebue Sound, about 200 miles southeast, near which there are several placer gold-mining districts of considerable importance. The whole region is exceedingly bleak and dreary. It is far beyond the northern limit of spruce timber and even the willows are stunted, the largest in the most sheltered places being not over 4 feet high. The nearest standing timber suitable for mining purposes is at the mouth of the Noatak, 150 miles southeast.

On account of the economic importance of the coal deposits and the scientific interest in the geologic formations known to exist there, a somewhat detailed examination of the field was undertaken by the United States Geological Survey in 1904, and to this work the writer was assigned. The important economic result of this expedition is the demonstration (1) that the coal fields are much more extensive than has generally been supposed, and (2) that there are two distinct coal-bearing formations in the region. One lies east of Cape Lisburne and contains low-grade bituminous coal of Jurassic age, the other lies south of the cape and includes highgrade bituminous coal of lower Carboniferous age.

a An abstract of this report has already appeared in the report on progress of investigations of mineral resources of Alaska in 1904, Bull. U. S. Geol. Survey No. 259, 1905, pp. 172-185. 


\section{HISTORY AND EXPLORATIONS.}

Captain Cook $a$ discovered and named Cape Lisburne in the year 1778, but coal was first reported in the region by Mr. A. Collie, ${ }^{b}$ who accompanied Captain Beechey to the Arctic Ocean in 1826 and 1827. The point of discovery by Mr. Collie was near Cape Beaufort, a minor headland of the coast line, 70 miles east of Cape Lisburne. Belcher and Collie of the Beechey expedition also collected paleontologic materials and made notes on the geology at Cape Lisburne and Cape Thompson. ${ }^{e}$

Kupreanoff and Fisher collected fossils at Cape Thompson and Cape Lisburne, and these were examined and reported on by Grewingk $d$ in 1848 and 1849.

During the last twenty-five years whalemen have often replenished their fuel supplies from these coal beds. The points most frequently visited were Corwin Bluff, 28 miles east of Cape Lisburne, where the United States revenue cutter Corwin, Captain Hooper commanding, coaled in 1881, $e$ and the Thetis mine, 36 miles east of Cape Lisburne, where the United States revenue cutter Thetis coaled in 1888 and $1889, f$ though both localities were probably visited by whalemen previous to either of the above dates.

Henry D. Woolfe $g$ and J. W. Kelly in the employ of the Pacific Steam-Whaling Company built a house and wintered at Corwin Bluff in 1884 or 1885 , but their attempts to operate coal mines met with little success. Paleobotanic collections from the coal-bearing formation and geologic notes were, however, made by Woolfe $h$ and some exploration of the interior was done by Kelly. $i$

Lieutenant Jarvis $j$ on the overland relief expedition to Point Barrow camped at the Corwin coal mine March 9, 1898, but found only a part of the Woolfe and Kelly house standing, most of it having been torn down for firewood by travelers en route to or from Point Barrow.

The discovery of gold at Nome in 1898 drew attention to these deposits as possible sources of fuel supply for the mines of Seward Peninsula, and several companies were organized to exploit them. Large areas of coal land were staked and several cargoes of coal, probably over 1,000 tons in all, were mined and sold at Nome in 1900 and 1901 , but since then the production has been merely nominal.

Schrader, $k$ of the United States Geological Survey, visited Corwin Bluff in 1901 at the end of his field season in northern Alaska, and collected notes on the geology of the region from various prospectors.

A more detailed examination of the region, made by the writer in 1904, gave the information contained in the present bulletin.

\section{ITINERARY.}

Under instructions from Alfred H. Brooks, geologist in charge, the writer, accompanied by Chester Washburne as field assistant, sailed on June 25, 1904, from Seattle and arrived July 4 at Nome, where final preparations were made. A boatman, Joseph Edge, was employed, and a large well-constructed dory of the type used by surfmen at Nome was purchased for the transportation of the party along the coasts of the Cape

a Cook, James, Voyage to the Pacific Ocean. London, Hughs, vol. 2, 1785, p. 460.

$b$ Buckland, W., Geology and Zoology of Captain Beechey's Voyage. London, Henry G. Bohn, 1839, p. 173.

c Buckland, op. cit., pp. 171-174.

i Grewingk, C., Beitrag zur Kentniss der orographischen und geognostischen Beschaffenheit der Nord-West-Küste Amerikas mit den anliegenden Inseln: Verhandl. Russ.-K. Mineral. Gesell. zu St. Petersburg, 1848, 1849.

$e$ Hooper, Capt. C. I., Report of the cruise of the United States revenue steamer Thomas Corwin in

the Arctic Ocean, 1881, 48th Cong., S. Ex. Doc. No. 204, pp. 49-50.

$f$ Stockton, Charles H., Arctic cruise of the U.S. S. Thetis in 1889: Nat. Geog. Mag., vol. 2, p. 178.

Geographic notes: Science, vol. 6,1885 , p. 381 .

$h$ Woolfe, Henry D., Arctic district of Alaska, population and resources: Eleventh Census, 1890, pp. 132-133.

iStockton, Charles H., Cruise of the U. S. S. Thetis in 1889: Nat. Geog. Mag., vol. 2, pp. 178-180.

$J$ Jarvis, D. F., Report of the eruise of the U.S. revenue cutter Bear and the Overland Relief

Expedition: Treas. Dept. Doc. No. 2101, 1899, p. 71 .

is Schrtider, F. C., A reconnaissance in northern Alagka: Prof. Paper U. S. Geol. Survey No. 20, pp. 109-114. 



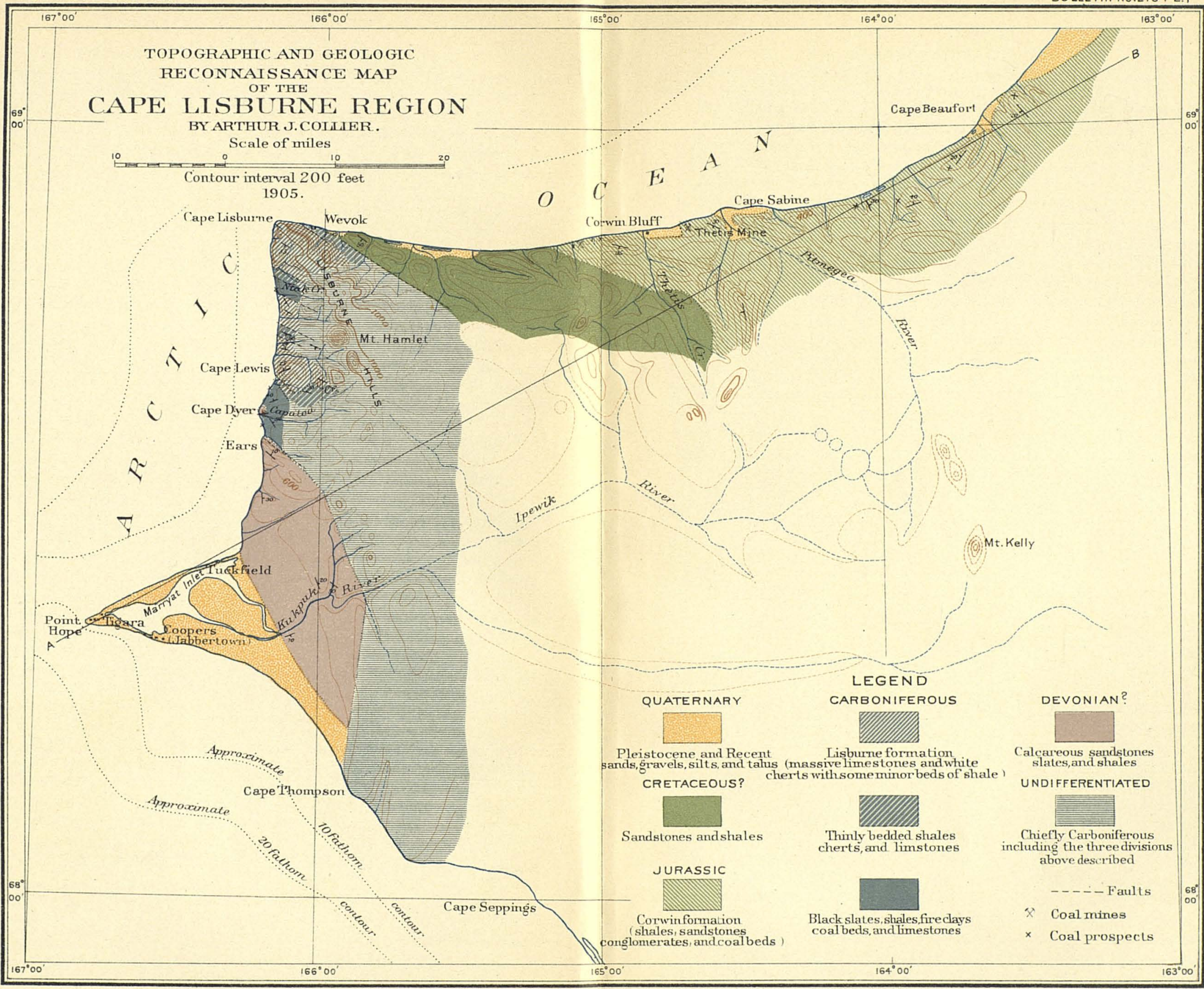



Lisburne region. The steamship Corwin, which was on a regular run between Nome and Cape Blossom, was chartered to transport the party to the Corwin mine, which is about one and one-half days' steaming beyond Cape Blossom. On account of the bad weather in the early part of July the party waited till the 17th to embark. During the next few days the weather was perfect as the ship sailed leisurely north ward, stopping at various points along the coast to put off passengers or freight. Stops of an entire day in each case were made at Teller, Deering, and Kiwalik. While the ship lay at Teller, C. J. Hutchinson joined the party as a volunteer field assistant and rendered valuable service throughout the season. The ice pack had now already retreated northward and the shores were green with vegetation. The atmosphere was filled with strange mirages making the low shores of Seward Peninsula loom up like fantastic dumb-bell-shaped mountains. It is said that under these atmospheric conditions a whaling ship 40 or 50 miles away can often be seen sailing bottom side up on the lower edge of a cloudy sea. Every night the sun dipped below the northern horizon merely long enough to show the sunset colors and then came up to begin the circuit of another day. Nor was the scene devoid of human interest, for frequently an overloaded "umiak," the carryall of an Eskimo family, would pull out from shore and ask a tow to the next village, or a solitary prospector in a dory or Peterboro canoe would row out to mail a letter and inquire the news. At Point Hope the ship wass surrounded by a swarm of small eraft loaded to the guards with Eskimo men, women, and children, who came on board to trade furs and ivory trinkets for alico, tobacco, and chewing gum. Here Mr. E. J. Knapp, an Episcopal missionary, who had been a very agreeable companion on the voyage, went ashore to remain throughout the winter, the only white man in the village of Tigara. When we sailed from this place, the members of the Geological Survey party were the only passengers on board.

On the morning of July 23 we rounded Cape Lisburne and were landed with equipment and supplies at Corwin Bluff. Camp was pitched at the mouth of a small creek east of the bluff, near the house of an Eskimo, who presented a paper which stated that his name was Cullinghow and that he had been placed by the president of the Arctic Development Company in charge-of the property. Two days later Joseph Tuckfield and John Hackman with a party of natives from Point Hope arrived at the mine and began to get out a supply of coal for use at the whaling station during the winter. They camped in a house built by the Corwin Trading Company 1 mile west of Corwin Bluff.

There was at this time no snow on the level ground, but along the shores the cliff faces were covered by the remnants of great snowdrifts accumulated the winter before, which had been undermined by the surf so that they presented ice cliffs often 75 to 100 feet high in front of the real cliff face (see PI. II, $B$ ). This condition interfered seriously with the work of the geologist, not only because the exposures were.covered up, but also on account of the danger from falling stones along the fuot of the cliffs while the ice melted. For a few days the weather was quite warm and mosquitoes were troublesome, but it soon became cold and stormy with almost continuous winds either from the south or northeast.

On July 26 most of the supplies were left in charge of Cullinghow while the party, with a light outfit, moved eastward along the coast toward Cape Beaufort. Camp was pitched that night at the mouth of Thetis Creek, 6 miles east of Corwin Bluff. Next day the weather became stormy, with a northeast wind and a heavy surf, and the party was stormbound for three days, during which time a somewhat detailed examination was made of the coast between Thetis Creek and Pitmegea River and of the drainage basin of Thetis Creek.

On the evening of July 29 the surf went down and a southwest wind came up. Camp was broken about $6 \mathrm{p}$. m. and the party put to sea, sailing while the wind lasted and rowing after it died down, and reached a point about 10 miles east of Cape 
Sabine, where a safe landing was made at $1 \mathrm{a} . \mathrm{m}$. , in spite of a heavy fog which settled down about midnight and made it almost impossible to see the shore.

On July 31 the attempt to continue the journey toward Cape Beaufort resulted only in filling the boat with water and covering a distance of about 1 mile, when owing to a heavy sea and head wind it was necessary to land and pitch camp. On account of the many delays, provisions were running short and it was evident that the party must soon return to the base of supplies, so at $3 \mathrm{p} . \mathrm{m}$. the writer started on foot along the beach to Cape Beaufort, about 15 miles distant, where he arrived. about midnight. This is the most northern point reached during the season. The cape is not marked by any angle in the coast line, but by a hill 500 feet high, onefourth of a mile back from the coast, whose slopes terminate along the coast in a bluff about 50 feet high with a narrow beach below. As the sun went down a heavy fog settled over Cape Beaufort and the writer made a hasty examination of the rocks exposed, collected a load of fossil plant specimens, and started back to camp within two hours of the time of his arrival.

On the evening of August 1 the boat loaded with camp outfit was successfully launched in spite of a somewhat heavy surf and sailed with a fair wind back to Corwin Bluff, arriving there about $1 \mathrm{a} . \mathrm{m}$. August 2. A heavy surf was running, and in landing the boat filled so that it was due only to good fortune and seamanship that a serious accident was averted. Though most of the outfit was wet, nothing was irreparably injured except one of the cameras, which was practically ruined. The collection of fossil plants which had been made was packed up ready for shipment to Point Hope and delivered to Tuckfield and Hackman, who, with their party of Eskimos, were still at the mine stormbound. During the next few days. the weather continued too stormy to permit moving camp along the coast. The northeast wind, which had blown steadily for nearly a week, was succeeded by a southerly gale, which though it laid the surf made a new danger, that of being blown out to sea. While stormbound here some further collections of fossils were made and the topographic mapping was extended several miles southward.

On August 6 the storm abated in the evening and camp was broken at 4 p. m. Since there was no wind, progress was made with oars and by towing along the beach for about 25 miles to Wevok, a native village about 3 miles from Cape Lisburne, where camp was again pitched at 7 a. $\mathrm{m}$. August 7 . Cape Lisburne is a famous wind hole and can be passed safely in a small boat only during fair weather. Within the next two days stormy weather began again and the party was detained at this place for a week. Even geologic work on land was done with great difficulty on account of the high wind. A party of two Eskimos and two white men from Point Hope, who were gathering driftwood south of Cape Lisburne, ventured offshore in a whaleboat and were blown out to sea and lost.

The morning of August 13 was fair and the outfit was successfully launched for a sail around the cape, just as the United States revenue cutter Thetis returning from her cruise to Point Barrow hove in sight. Picking the party up, she landed them safely at Cape Lewis, about 10 miles south of Cape Lisburne, where the coal beds of the Carboniferous series were examined.

On August 16 camp was moved to the entrance to Marryat Inlet, and next day to the whaling station on the south side of Point Hope. Leaving the camp here, the writer returned to the north side of the point and ascended the Kukpuk River, which flows into Marryat Inlet.

The whole party sailed from Point Hope on the United States revenue cutter Thetis on August 22, and were landed at Cape Prince of Wales August 23 to make an investigation of the developments made during the season in the tin deposits of the York region. During the field work Mr. Washburne was mainly employed in collecting fossils, while the writer, assisted by Mr. Hutchinson, was more especially occu- 


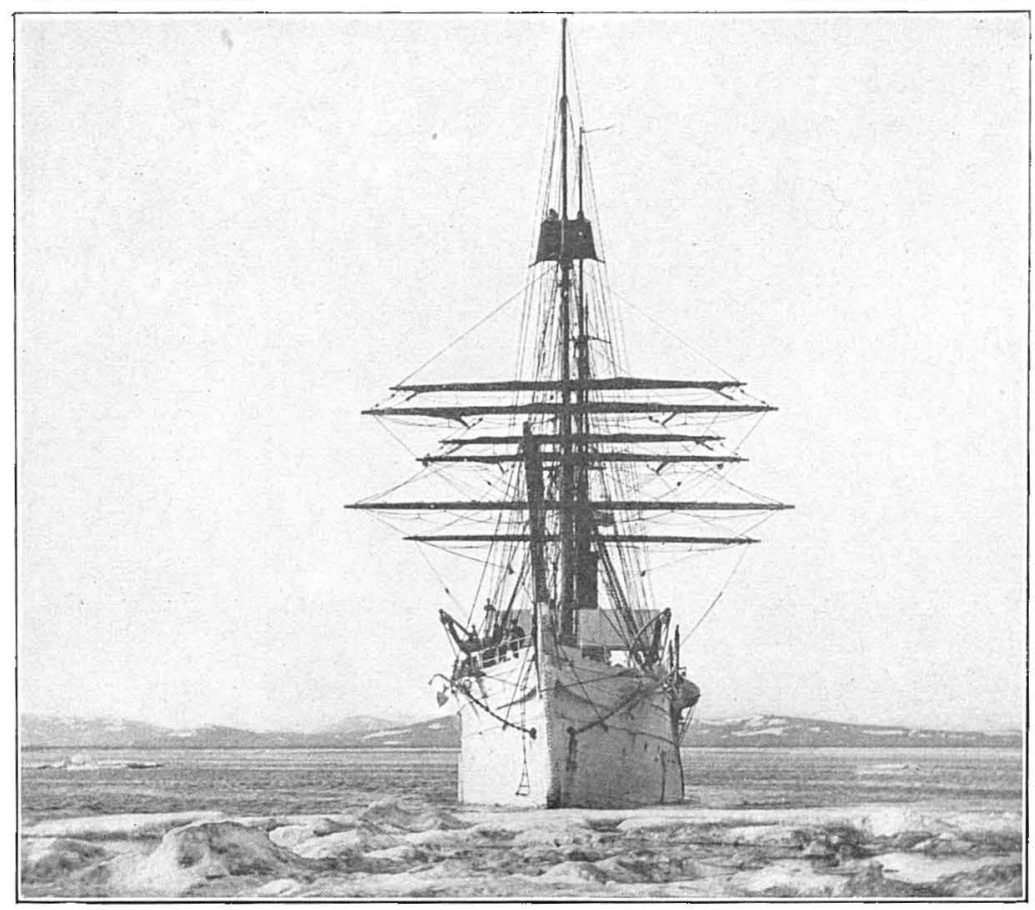

A. U. S. REVENUE CUtTER thetis in the EdGe of an ice floe. Showing difficulties of navigation in the early season in the Arctic Ocean and Bering Sea.

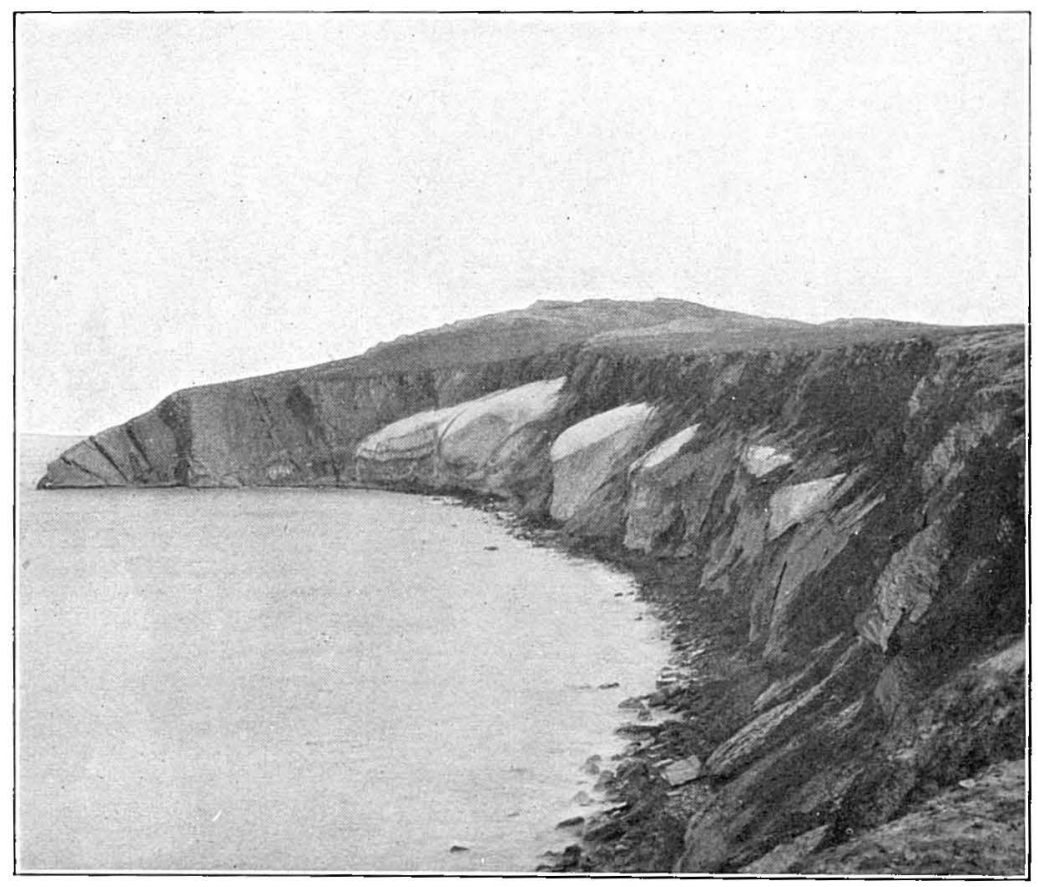

13 CLIFFS WEST OF CORWIN BLUFF.

Corwin mines a'e in the foregrcund. 

pied in the preparation of a topographic map, the examination of the coal beds, and the investigation of the more general stratigraphic relations.

On August 27, at the mouth of Lost River, the Thetis again took the party on board and after a cruise in Bering Sea, in the course of which landings were made on St. Lawrence, St. Matthew, and Unalaska islands and on the Siberian coast, points seldom visited by geologists, we arrived at Port Townsend on September 30 .

\section{ACKNOWLEDGMENTS.}

The writer wishes to express his appreciation of the services of the other members of his party, Messrs. Washburne, Hutchinson, and Edge, all of whom were faithful and untiring in spite of many discomforts and hardships, and contributed much to the fund of information obtained.

Similar acknowledgments are due to Captain Hamlet and the officers of the United States revenue cutter Thetis, who brought the party from Point Hope to Seattle, and who furnished every convenience possible for our investigations.

Special thanks are due to the following residents of the Cape Lisburne region, whose hospitality and courtesy were unbounded: Joseph Tuckfield and John Hackman at considerable inconvenience transferred several hundred pounds of rock specimens from the Corwin mine to Point Hope and looked after their shipment. They also furnished the writer with a map of the interior compiled from the explorations of a number of natives. Later Mr. Tuckfield accompanied the writer on his trip up Kukpuk River. Mr. H. Koenig, commonly known as "Cooper," furnished an almost continuous meteorologic record, taken at the whaling station for five years. And finally Cullinghow, the Eskimo watchman at the Corwin mines, faithfully looked after our stores and camp while we were on the trip to Cape Beaufort and also furnished useful information and a map showing the drainage and routes of travel in the interior portion of the region.

Acknowledgments are also due to the paleontologists, paleobotanists, and chemists, without whose reports on the materials collected this bulletin would lose much of its scientific value. David White examined and reported on the Paleozoic plants; G. H. Girty examined the large collection of Paleozoic invertebrates, and F. H. Knowlton examined the large collection of Mesozoic plants from the Corwin formation. The samples of coal collected by the party from various beds of both the Corwin and Lisburne formations were assayed by W. T. Schaller in the Survey laboratories.

\section{GEOGRAPHY.}

The Cape Lisburne region, as discussed in this paper, comprises the northernmost of the four great land masses which project from the western coast of Alaska. Its general position and the details of coast-line settlements, drainage, and topography appear on the reconnaissance map, Pl. I., which is based on Beechey's chart, the field notes of the writer, and information obtained from prospectors and natives who have penetrated the interior beyond the limit of this expedition. No accurate topographic surveys have been made.

\section{COAST XINE.}

A reference to these maps will show that Point Hope, which is called "Tigara" (the index finger) by the natives, is the most western point in the region. Southeast of Point Hope the coast is made up of long concave stretches of beach between minor promontories and extends in an approximately straight line for 180 miles to Kotzebue Sound. The southern point of the area under discussion is Cape Thompson, which is about 35 miles southeast of Point Hope. This cape is formed by a series of sea cliffs about 500 feet high, extending in a southeast direction for about 6 miles, and a concave beach line extending northwestward from it to Point Hope. At Point Hope the coast line makes an acute angle and extends eastward in a slightly 
convex line of beaches for 16 miles, where it turns northward forming a reentrant angle. From this point to Cape Lisburne, a distance of about 30 miles, the coast line is marked by a series of cliffs, usually with narrow beaches before them, forming an approximately straight line. At Cape Lisburne the coast line makes a seeond acute angle and extends east for about 28 miles to Corwin Bluff. It then gradually curves northward to Point Lay, 100 miles from Cape Lisburne and beyond the limit of this investigation. The Cape Lisburne cliffs extend east from the cape for about 2 miles where a line of beaches begins, which is almost continuous to Point Barrow. In many places narrow lagoons occur back of these beaches. They increase in size toward the northeast, and the largest ones are outside of the province of this report.

Wherever cliffs occur along this part of the coast they are usually less than 200 feet high and have narrow beaches below them, and if it were not for the snowdrifts, which in many instances remain all summer, it would be possible in calm weather to traverse the beach nearly all the way from Cape Lisburne to Point Lay. Along this part of the coast there are few prominent features. The ones worthy of mention are Corwin Bluff, Cape Sabine, and Cape Beaufort. Corwin Bluff, 28 miles east of Cape Lisburne, is a headland 200 feet high, projecting only slightly beyond the regular coast line and interrupting the continuity of the beach for only a few hundred yards. (See Pl. II, B.) Cape Sabine, about 40 miles east of Cape Lisburne, is a low point, not well defined, projecting possibly one-fourth of a mile into the sea. Cape Beaufort, about 70 miles from Cape Lisburne, is not marked by any bend in the shore line, and the name is applied to a hill about 500 feet high, one-fourth of a mile back from the shore.

The region contains no harbor suitable for vessels drawing nore than 10 feet. The nearest harbor for such vessels is Kotzebue Sound. Marryat Inlet at Point Hope is a good harbor for vessels drawing 10 feet or less. The entrance is on the north side of the point, and is difficult in rough weather on account of a shoal extending some distance offshore. $a$

\section{THE ARCTIC OCEAN.}

The adjacent parts of the Arctic Ocean are generally shallow, probably nowhere exceeding 35 fathoms in depth. West of Point Hope 13 fathoms is carried within one-fourth mile of the beach, but north of Point Hope a depth of only 5 fathoms is found half a mile from shore. In the bight north of Cape Lisburne the water is shallow but the bottom is regular and good anchorage can be had from 1 to 2 miles offshore.

The following paragraphs on the distribution of ice packs and currents in the Arctic Ocean are taken almost verbatim from the bulletin by Lientenant Jarvis: $b$

During the winter months the ocean as far north as Cape Prince of Wales is covered by an impenetrable ice pack, which rises in irregular masses 10 to 25 feet above the water. Though the pack contains no real icebergs it nevertheless extends 6 to 8 fathoms below the water and occupies from a third to a half the depth of the shallow Aretic Sea. Few ships have been built that will stand its crushing force, and no ram ever constructed is powerful enough to break its way through it.

The southern limit of the ice is determined almost entirely by the direction and force of the winter winds, since it is in part the product of each winter's freezing and in part the acclumulation of many winters driven down from the north.

It is reported that heavy sontherly winds and swells break up the ice, and if these are followed by northerly winds it spreads out and offers navigable channels. Northeast winds tend to drive the ice off the American shore, and westerly winds off the Siberian shore. Bering Strait is usually open by the first week in July and sometimes earlier, but clear water does not extend far northward, and it is seldom possible for ordinary vessels to reach Point Hope before July 10 or 15 . By July 15 the main pack has usually moved north of Cape Lisburne, but thinner " ruthning ice" from Kotzebue Sound is usually encountered at Point Hope sometime after the pack has moved north. Thus far the move-

a Jarvis, D. H., Coast Pilot Notes on the Fox Islands passes, Unalaska Bay, Berjng Sea, and Arctic Ocean as far as Point Barrow. Bull. U. S. Coast and Geodetic Survey No. 40, 2d edition, 1900, p. 56.

bJarvis, D. H., Bull. U. S. Coast and Geodetic Survey No. 40, 2d edítion, 1900, pp. 49-52. 
ments of the ice do not appear to depend to any great extent on the winds and they are reasonably certain each year.

When the ice pack moves off the coast in the early summer it leaves a strip of quiet water between it and the shore, which can be taken advantage of instead of harbors by ships lightering coal and other materials from the land. Later in the season when the ice has moved farther out to sea there is no protection for vessels. The difficulties of navagation early in the season are shown in the photograph, Pl. II, $A$.

From Bering Strait to Point Barrow there is a general current in the ocean setting northward along the shore, which, when not affected by the winds or stopped by the ice, has an average velocity of not less than 1 knot per hour. At Point Hope its velocity is from $1 \frac{1}{6}$ to 2 knots, but north of Cape Lisburne it does not exceed 1 knot.

In the bight north of Point Hope there is probably an eddy which causes a local current to the west along the north shore of the point. In the bight north of Cape Lisburne there is said to be a tidal current, and unless driven in by westerly winds the outside general current is not felt.

\section{CLIMATE.}

Records of temperature have been kept at Point Hope almost continuously for the last sixteen years. The lowest temperature recorded is $-48^{\circ}$ Fahrenheit in February, 1892. The highest temperature recorded was $97^{\circ}$ in July, 1891. During the year 1904 the lowest temperature was $-12^{\circ}$ in February, and the highest $67^{\circ}$ in July. $a$

The coldest days are apt to be calm, but fierce blizzards from the northeast are of frequent occurrence and the temperature during the winter rarely rises above zero. The average temperature recorded while the party was in the field last summer was $48^{\circ}$. During the summer the winds blow alternately from the south and the northeast, periods of calm intervening. In the month between July 22 and August 22 , 1904, while the Geological Survey party were in the Cape Lisburne region there were not more than ten calm days. The heaviest summer storms come from the southwest. These occur only occasionally, sometimes at intervals of years, and are shortlived but very severe and disastrous, as there is little protection from the wind in that quarter. $b$

Though no such storm occurred during the season of 1904, evidences of storms were observed, such as driftwood piled high above the usual reach of the tide at the east ends of the lagoons.

\section{LIFE.}

Vegetation consists only of very hardy plants, most of which reach their maturity in the short season. Willows not over 4 feet in height grow in sheltered places along some of the water courses. These are the largestplants the region can produce and are usually not large enough for firewood. Grasses and some flowering plants are to be found almost everywhere, though with very few exceptions these are too scanty to afford forage for horses. Mosses and lichens are also abundant, but no extensive patches of reindeer moss were seen.

Caribou are still seen occasionally, but are very rare. Mountain sheep formerly abundant in the region were reported as late as 1881, but are now probably extinct. $c$ White foxes and polar bears are abundant and their skins are a source of revenue to the natives.

- Among birds ptarmigan can be found in many places on land, while along the seashores and the rivers and ponds of the interior geese and ducks are very abundant during the summer. The most prized are probably the eider ducks, which fly south along the coast in great numbers in the fall. The cliffs at Cape Lisburne and Cape Thompson are famous nesting places and are frequented by myriads of sea fowls, including gulls, sea parrots, and murres. Great numbers of eggs are gathered here each year by the natives. The cries of the birds, which can be heard for several miles, serve as warning signals to passing ships during foggy

$a$ Communicated to the writer by H. Koenig.

$b$ Jarvis, D. H., Bull. U. S. Coast and Geodetic Survey No. 40, 2d edition, 1900, p. 52

- Hooper, Capt. C. L., Cruise of the Corwin in 1881. 48th Cong. S. Ex. Doc. No 204, p. 50. 
weather. In the bight north of Cape Lisburne thousands of broods of young ducks congregate while their feathers are growing, and in years past have afforded good sport as well as an abundance of fresh meat to the crews of the whaling fleet.

\section{SETTLEMEN'TS.}

The location of settlements and villages in this region is determined by the proximity of hunting and fishing grounds. Formerly there were villages along the rivers of the interior, but since the caribou and sheep have disappeared the settlements are confined to those points along the coast where fish, seals, walrus, and whales can be killed or where the bird rookeries are accessible.

The principal settlements are located on the Point Hope peninsula, which projects far out into the ocean and forms an ideal base for sealing and whaling operations. It is also in close proximity to the largest river of the region, where an abundance of salmon can be obtained and where in the fall of the year great flocks of geese and ducks congregate in their migration from points farther north. The settlements here consist of a native village $a$ called "Tigara," at Point Hope, and of a number of whaling stations maintained by white men distributed for 6 or 7 miles along the south side of the peninsula.

At the breaking of winter leads of open water form in the ice pack often several miles from land and the whalemen move out to the edges of the shore ice and camp there through the whaling season, which lasts about a month. When a whale is sighted it is attacked from the ice if the lead is narrow, or from canoes and boats if the lead is wide. Native skin canoes are preferable for this purpose, since they are light and can easily be sledded over the ice. Ivory-pointed harpoons with detachable shafts and sealskin lines attached to floats made of whole sealskins sewed up and inflated with air are used to prevent the escape of the whale, and as soon as possible it is killed by an explosive projectile from a bomb gun. This weapon, which has a caliber of about 1 inch, may be fired from the shoulder or may be mounted in the bow of the attacking boat. When killed the whale is towed 10 the edge of the ice and, if possible, hauled out of the water with tackles. The whalebone belongs to the hunters and is chopped out with axes, but the meat belongs to the entire village. The natives swarm around the carcass with axes and spades, each family striving to get as much of the meat as possible. Almost every part is saved and stored in underground houses, where it is kept frozen until used. The whaling stations kept by white men usually employ a number of natives, and on account of the high price received for whalebone the business is profitable, even if not more than one or two whales are killed during the season.

The center for this whaling industry is about 6 miles east of Tigara village and is locally called "Jabbertown," probably on account of the mixture of Eskimo and English languages spoken there. The oldest whaling station, known as "Coopers,". was established in 1887. There is also a smaller station owned by Joseph Tuckfield $b$ on the north side of the point at the entrance to Marryat Inlet. One of these whaling stations, that of James Allen at Jabbertown, is shown in Pl. III, $B$.

An Episcopal mission and school has been maintained for several years at Tigara and a Government schoolhouse was built near Coopers station in 1904.

The total population in the various settlements at Point Hope is probably about 300 , all but 20 or 30 of whom are natives. $c$

a According to Lieutenant Ray Point Hope is called "Tikera" by the natives of Point Barrow. This is also their word for the forefinger. Report of the expedition to Point Barrow, Alaska, 1885; 48th Cong., H. Ex. Doc. No. 44, p. 55.

bA reference to Tuckfield's explorations in northern Alaska is made by Lieutenant-Commander C. H. Stockton in the Arctic cruise of the U. S. S. Thetis: Nat. Geog. Mag., vol. 2, p. 183.

c Capt. E. E. Smith estimated the native population at Tigara in 1880 at 276 : Tenth Census, vol. 7 , p. 4. Henry D. Woolfe estimated the population at Tigara in 1890 at 295: Eleventh Census, Alaska, p. 158. Lieutenant Bertolf, 1898, puts the fpopulation of Tigara at 250: Cruise of the U. S. revenue cutter Bear, p. 25. The Twelfth Census puts the population of Point Hope village at 623: Twelfth Census of the United States, 1900, vol. 1, 1901, p. 426 . 
The settlement is evidently very old, for the graveyard contains the ruins of thousands of graves. According to tradition the village had a population of 2,000 in the later part of the eighteenth century, $a$ but wars with neighboring tribes and diseases and vices introduced by the whalemen who had their rendezvous there have reduced it to the present number.

Near Cape Thompson there is a small native village whose population was estimated at 40 in $1880, b$ but it has not been mentioned in census reports since then. There is also a small village of two houses at Wevok, 2 miles east of Cape Lisburne. At Corwin Bluff, 28 miles east of Cape Lisburne, the population in 1904 consisted of 3 people, the native watchman and his family.

Outside of the Cape Lisburne region the nearest important settlements are on the south shores of Kotzebue Sound, where there are two thriving towns, the distributing points for a mining region of considerable promise. $c$ These towns. bear an important relation to the subject of this paper, since they offer an immediate market for a limited amount of coal.

\section{TOPOGRAPHY.}

Two well-marked topographic provinces have been recognized in the northern part of Alaska - the Rocky Mountain system, including several mountain ranges and forming the western continuation of the Rocky Mountains of the United States and Canada, and the Arctic Slope region, including the part of Alaska lying north of the mountains. The Cape Lisburne hills have been regarded as the western extremity of the Rocky Mountain axis, and their geologic structure seems to verify this belief, though the topographic continuity of the mountain axis has not yet been established. The Arctic Slope region extends north ward from Cape Lisburne.

By its topographic features the Cape Lisburne region can be divided into three portions - a foreland, a mountainous upland belt, and a.rolling upland of moderate relief:

The first of these is the Point Hope peninsula, a triangular area about 11 miles wide at its base next to the mainland, and extending 16 miles out to sea. It consists of two.low sand spits which converge near the point, the space between being occupied in part by the large lagoon called "Marryat Inlet," and in part by the delta deposits of Kukpuk River. Its total area is about 88 square miles; more than half is land; no part rises more than 20 feet above the sea. In technical language it can be described as a typical cuspate foreland.

The uplands of high relief lie east of the Point Hope foreland and extend from Cape Lisburne in a southeasterly direction to Cape Thompson. They will be referred to as the "Lisburne Hills." Mount Hamlet, 8 miles southeast of Cape Lisburne, is the highest point and attains an altitude of about 2,500 feet.

The north end of the Lisburne Hills consists of a series of dome-shaped buttes rising above a plateau about 1,000 feet high, but at the south end near Cape Thompson the plateau is only about 600 feet high, and the surmounting buttes are almost entirely wanting. That this plateau is of erosive origin is indicated by waterworn pebbles from the neighboring bed rock, which can be seen at various pläces on its surface. In being elevated to its present position it has suffered considerable deformation. On the east side of the Point Hope foreland it approaches sea level, but farther east it rises gradually. This deformation is shown in profile in the cliffs north of Point Hope which cut the surface of the plateau. Near the base of the peninsula the cliffs are not over 30 feet high; while at the Ears, 10 miles north, they rise 600 feet from the sea to the plateau surface. The plateau is deeply incised

a.Stockton, C. H., Arctic cruise of the U. S. S. Thetis in 1889: Nat. Geog. Mag., vol. 2, pp. 195-196.

$b$ Tenth Census, vol. 7, p. 4 .

c Moffit, F. H., The Fairhaven gold placers of Seward Peninsula, Alaska: Bull. U. S. Geol. Survey No. 247, 1904 . 
by many short streams, which flow west into the ocean, and by Kukpuk River, which rises east of the mountains and flows through them in a narrow canyon. Some of the smaller streams in this belt occupy hanging valleys truncated by the sea cliffs, but the larger ones are reduced to bace-level and have rather wide valleys at their mouths.

The northeast face of the range near Cape Lisburne is marked by a prominent escarpment about $\mathrm{P}, 000$ feet in height, extending southeast from the coast for several miles, Thel to a well-defined fault in the bed rock. No topographic connection meen bestablished between the Lisburne Hills and any mountain system of the interior, but several maps drawn for the writer by natives show a low range of hills extending eastward from Cape Thompson, which, if they exist as shown, may be continuous with the western extension of the Rocky Mountain system.

The third topographic division is a portion of the Arctic Slope province of Alaska, and lies northeast of the Lisburne Hills. It is an extensive region of low rolling hills and ridges, with occasional flat valleys of limited extent. Flat surfaces covered with rounded pebbles of local origin occur on the higher portions at elevations of 500 and 800 feet and indicate old levels of erosion. This upland is essentially a peneplain with a close adjustment of drainage and topography to bed-rock structure. It is apparently the product of erosion during two periods in which the land stood, respectively, 800 and 500 feet lower relative to sea level. When these surfaces were elevated to their present position, they also suffered some deformation, and during the latest uplift, which occurred since the Tertiary, local benches were formed along the shore and Pleistocene gravels were deposited on them. (See pp. 32-33.) Between Cape Lisburne and Cape Sabine the ridges have a uniform trend abo'it S. $75^{\circ} \mathrm{E}$., corresponding with the prevailing bed-rock structure, as is shown in Pl. VII. East of Cape Sabine the trend of the ridges is not so uniform, though it still corresponds with bed-rock structure.

An isolated mountain 1,300 feet high, about 6 miles south of Corwin Bluff, rises 500 feet above the highest erosion level noted. From this mountain the low, rolling, hilly region is seen to extend far to the east and south. About 20 miles south of Cape Beaufort there are several small mountains which rise above the surrounding country. The highest of these is probably Mount Kelly, which on all maps of Alaska published since 1900 has appeared in a position about 40 miles southeast of that indicated by bearings taken by the writer during the season of 1904 . This mountain probably has an elevation of 2,500 feet and rises above the rolling upland, whose highest points scarcely attain 1,000 feet.

Along the coast toward Point Barrow, beyond the region here described, the hills become lower and the relief less pronounced, so that the undulating upland of the Cape Lisburne region merges with a plain slightly above sea level in the Point Barrow region.

Along Colville and Anaktuvuk rivers, as described by Schrader, the Arctic slope north of the Endicott Mountains shows similar features. $a$

Beginning at the northern base of the Endicott Mountains, one of the ranges composing the Rocky Mountain system, at an elevation of 2,500 feet, a gently rolling plateau extends with gradual slope north ward for a distance of 80 miles to latitude $69^{\circ} 25^{\prime}$, where at an elevation of 800 feet begins the nearly flat coastal plain which descends to the sea level at the Arctic coast 80 miles farther north. The plateau country is apparently a peneplain having a complete adjustment of drainage and topography to the bed-rock structure, which resembles that of the northern part of the Cape Lisburne region. The coastal plain, however, is probably a constructional feature since it is developed over horizontally bedded Tertiary sediments. No such

a Schrader, F. C., Reconnaissance in northern Alaska: Prof. Paper U. S. Geol. Survey No. 20, 1904, pp. $45-46$. 
constructional plain occurs in the Cape lisburne region, though it is probable that the coastal plain at Point Barrow is of this type.

The section described by Schrader is about 350 miles east of Cape Lisburne. Similar topographic relations in the intervening country are reported by Howard and other explorers, so that the continuation of the rolling upland of the Cape Lisburne region to the east for 300 miles or more and its correlation with Schrader's Anaktuvuk Platean can be reasonably inferred.a The average elevation of this upland is about 500 feet in the Cape Lisburne region and from 800 to 2,500 feet along Anaktuvuk River.

\section{DRAINAGE.}

The drainage of the Cape Lisburne region is controlled by one large river, the Kukpuk, whose basin occupies the whole inland portion, while the numerous other streams which reach the coast drain only a small part.. The Kukpuk, whose name signifies big river, discharges by several mouths into Marryat Inlet, the large lagoon of the Point Hope foreland. The first 15 miles of its course above its delta is across a low plateau, in which it is entrenched to a depth of about 100 feet, and farther up it traverses the Lisburne Hills in a deep canyon, probably not less than 10 miles it length. Above the canyon it forks. The north fork, called Ipewik River, is saif to rise in a large lake or series of lakes west of Mount Kelly, about 60 miles southeast of Cape Lisburne. A large northern tributary of the Ipewik rises near the northern coast line about 6 miles south of Corwin Bluff. The south fork of the Krkpuk, as represented on native maps, rises south of Mount Kelly and flows westward in a general way parallel with the north fork to its junction with it. Its headwaters can not be far from the Noatak or from the headwaters of the Kivalina, which reaches the coast south of Cape Thompson.

Between Point Hope and Cape Lisburne several small streams, none of which are over 10 miles in length, rise in the Lisburne Hills and flow westward to the coast. Between Cape Lisburne and Corwin Bluff several small creeks reach the coast, which rise in the Lisburne Hills and flow north ward.

East of Corwin Bluff three larger streams, Thetis Creek, Pitmegea River, and Kukpowruk River, drain the region north of the Kukpuk basin. Thetis Creek empties into the ocean about 33 miles east of Cape Lisburne. Except for about a mile at its mouth it is not navigable even by canoe. The main creek cuts across the trend of the ridges, while its tributaries flow parallel with them, their courses determined by bed-rock structure. It rises about 16 miles from the coast, not far from the headwaters of the Ipewik.

Pitmegea River enters the Arctic a half mile west of Cape Sabine and about 40 miles east of Cape Lisburne. It is considerably larger than Thetis Creek, and, like the latter stream, it has a lagoon at its mouth, which extends inland for some distance, but except in time of freshet it is hardly navigable for canoes. It is said by natives to head in the same lake as the north fork of the Kukpuk, which lies southeast of Cape Sabine and about 20 miles inland. From its source the course of the river roughly describes a semicircle, flowing first northeast, then north, then northwest to the sea. This course is probably determined by bed-rock structure. For some distance up from the mouth the valley is reported to be broad and filled with gravels and ground ice.

Kukpowruk River flows into a lagoon which begins about 10 miles northeast of Cape Beaufort and extends along the coast nearly to Point Barrow. This river, like the others of the region, is said to rise near Mount Kelly, from which point it flows northward in a sinuous course to its mouth. Native maps show a large river, called Utukok, east of the Cape Lisburne region, which rises near the Noatak and flows north to the Arctic, near Icy Cape. 


\section{ROUTES OF TRAVEL.}

The most frequented routes of travel are naturally by boat along the coasts. Two trails overland from Point Hope to Corwin Bluff were shown on a map drawn by natives. One of these follows the coast line north ward from Point Hope and crosses the Lisburne Hills near Wevok. The other crosses the mountains by way of Kukpuk Canyon, and then follows up a northern tributary, which heads about 6 miles south of Corwin Bluff.

Winter travel between Point Barrow and Kotzebue Sound usually leaves the coast at Kukpowruk or Pitmegea River, and reaches the coast again at the mouth of the Kivalina River, south of Cape Thompson, thereby saving considerable distance.

W. T. Lopp, a with the reindeer herd of the Point Barrow relief expedition, followed this route in 1898. An old route through the interior from Kotzebue Sound to Icy Cape, said to have been used by the natives in years past, is up the Noatak and one of its northern tributaries to the headwaters of the Utukok, which flows into the sea at Icy Cape. $b$

\section{GEOLOGY.}

\section{STRATIGRAPHY.}

The rocks of the Cape Lisburne region are, so far as known, all sedimentary. The bed rocks fall naturally into two groups-the Paleozoic and Mesozoic-and their distribution is indicated by the topography, since the Paleozoic rocks produce the high relief of the Lisburne Hills while the Mesozoic rocks underlie the region of Jow relief which lies northeast of them. Pleistocene and Recent sediments and ground ice form a third group, whose greatest area is found in the Point Hope peninsula. The distribution of the various formations is shown on the geologic map, PI. I. The general stratigraphic relations are shown in the following tabular statement:

Tabular statement of stratigraphy, Cape Lisburne region, Alaska.

\begin{tabular}{|c|c|c|c|c|}
\hline Age. & $\begin{array}{l}\text { Formation } \\
\text { name. }\end{array}$ & $\begin{array}{l}\text { Contact } \\
\text { relations. }\end{array}$ & $\begin{array}{l}\text { Thick- } \\
\text { ness in } \\
\text { feet. }\end{array}$ & Lithologic eharacter. \\
\hline Recent ......... & (n. & Unconformity .. & $50+$ & Sands, gravels, etc. \\
\hline Pleistocene.......... & (................... & Unconformity.. & $50+$ & $\begin{array}{l}\text { Gravels, silts, taitus, and ground } \\
\text { ice. }\end{array}$ \\
\hline Lower Cretaceous?.. & .... & Conformity..... & $10,000+$ & $\begin{array}{l}\text { Sandstones interbedded with } \\
\text { shales. Nonfossiliferous. }\end{array}$ \\
\hline Upper Jurassic & Corwin ........ & Unconformity... & $15,000+$ & $\begin{array}{l}\text { Calcareous and carbonaceous } \\
\text { shales with sandstones and } \\
\text { conglomerates at infrequent } \\
\text { intervals. Many coal beds. } \\
\text { Jurassic plants. No marine } \\
\text { fauna. }\end{array}$ \\
\hline $\begin{array}{l}\text { Lower Carboniferous, } \\
\text { Mississippian. }\end{array}$ & Lisburne .... & $\begin{array}{l}\text { Conformity..... } \\
\text { Conformity..... } \\
\text { Conformity?.... }\end{array}$ & $\begin{array}{r}3,000+ \\
1,000+ \\
500+\end{array}$ & $\begin{array}{l}\text { a. Massive limestones inter- } \\
\text { stratified with white cherts. } \\
\text { Extensive coral and bryozoan } \\
\text { fauna. } \\
\text { b. Thinly bedded shales, slates, } \\
\text { cherts, and limestones. Fauna } \\
\text { includes brachiopods, trilo- } \\
\text { bites, cephalopods, and lamel- } \\
\text { librunchs. } \\
\text { c. Thinly bedded black shales, } \\
\text { slates, and limestones. Sev- } \\
\text { eral coal beds. Lower carbon- } \\
\text { iferous flora. Brachiopod and } \\
\text { coral fauna. }\end{array}$ \\
\hline Devonian? . & & & $2,000+$ & $\begin{array}{l}\text { Calcareous sandstones and } \\
\text { slates. No fossils found. }\end{array}$ \\
\hline
\end{tabular}

a Jarvis, D. H., Report of the cruise of the U.S. revenue cutter Bear: Treas. Dept. Doc. No. 2101, pp. $67-68$.

$b$ Jarvis, D. H., Report of the cruise of the U. S. revenue cutter Bear: Treas. Dept. Doc. No. 2101 , p. 72. 


\section{PALEOZOIC FORMATIONS.}

DEVONIAN ROCKS.

Probably the oldest formation of the region consists of heavy calcareous sandstones and interbedded calcareous slates, which occur on the weat side of the Lisburne Hills, where they form the sea cliffs for about 15 miles north of Marryat Inlet, and are exposed for about 10 miles along Kukpuk River. The heavy sandstones range in thickness from 1 to 10 feet each, while the slaty beds are usually thinner. The massive members often present schistose phases and contain secondary mica. The total thickness has not been determined, though it is certainly not less than 1,000 feet.

The structure consists of a series of broad, open folds, whose dips rarely exceed $30^{\circ}$. The beds being massive, the strains to which they have been subjected have been taken up in two sets of well-defined joint planes in the harder members, and a slaty cleavage in the softer. The most prominent system of jointing varies in strike from N. $20^{\circ} \mathrm{W}$. to $\mathrm{N} .50^{\circ} \mathrm{W}$, and is more nearly vertical than horizontal. The other set of joints strikes northeast. The relation of jointing in the harder beds to slaty cleavage in the softer is exposed with diagrammatic clearness at the high cliffs called the Ears, about 3 miles south of Cape Dyer (see fig. 1).

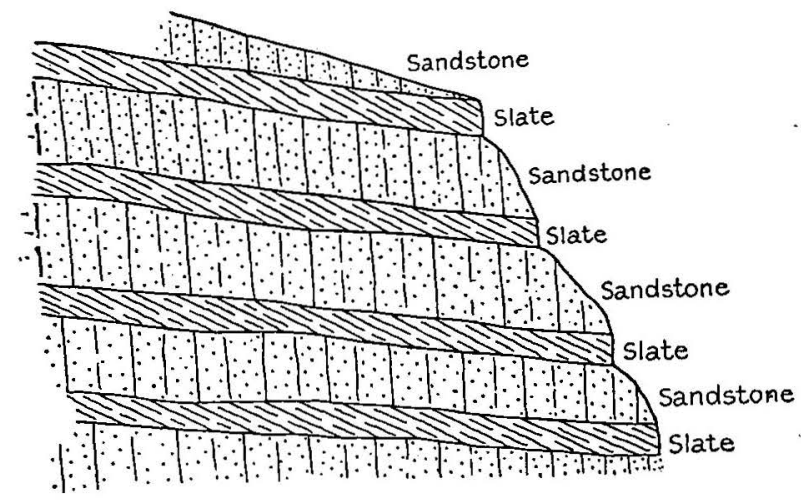

FIG. 1.-Sketch of detail of jointing and eleavage in pre-Carboniferous rocks south of Cape Dyer.

Calcite and quartz veins are often developed along the joint planes. They have - been prospected in some instances, but, so far as is known, have yielded no traces of gold or silver. One of the largest seen, a calcite vein 5 or 6 feet thick near Point Hope, has furnished material which was burned by the natives and used in tanning.

The age of the formation is inferred from its relations to the Carboniferous beds which overlie it with apparent conformity, though no direct paleontologic evidence could be obtained. It is certainly older than Lower Carboniferous and is tentatively placed in the Devonian.

The Devonian rocks identified in other parts of Alaska ${ }^{a}$ are widely distributed, but seem to be characterized mainly by great divergence in lithology, and none of them can be definitely correlated with those of the Cape Lisburne region. In the Seward Peninsula, 160 miles south of the region, there is an extensive metamorphic series consisting of schists and massive limestones which is shown by fossil evidence to be mainly of Silurian age. In the western extremity of the peninsula the rocks of this series give place to a series of slates which are in contact on their west side with Carboniferous limestones now correlated on paleontologic evidence with the

a Brooks, A. H., The geography and geology of Alaska: Prof. Paper U. S. Geol. Survey No. 45, pp. 218-221.

Bull. 278-06-2 
Carboniferous rocks of the Cape Lisburne region. $a$ These slates, although universally finer grained than the rocks north of Marryat Inlet, bear some resemblance to them and possibly may ultimately be correlated with them.

In the Yukon River basin a widely distributed group of rocks called the Rampart formation has been assigned to the Devonian. The rocks, however, consist mainly of volcanic materials with interbedded siliceous limestones, cherts, and slates. $b$ Specimens of some of these rocks collected by Prindle" in the Rampart region seem to be almost identical with those collected near Marryat Inlet by the writer, but the group as a whole bears no resemblance to the sandstone formation near Cape Lisburne.

\section{CARBONIFEROUS ROCKS.}

The Carboniferous rocks lie east of the area of sandstones and slates just described and constitute the mass of the Lisburne Hills. They are well exposed for 20 miles in the high bluffs along the coast south of Cape Lisburne, for several miles at Cape Thompson, and in the canyon of Kukpuk River, which flows across the Lisburne Hiils. Their inland extension has not been determined, though they are provisionally correlated with some lithologically similar rocks found on Colville and Anaktuvuk rivers $d 300$ miles to the east.

The contact of these rocks with the supposed Devonian sandstones and slates has been observed at three localities. In two of these localities situated north and south the relation seems to be conformable, while in the third, 2 miles farther south of Cape Dyer, the contact is a well-defined,thrust fault with the sandstone overlying (see fig 2, p. 19).

As shown on the geologic map, Pl. I, the general area of undifferentiated Carboniferous, which is approximately outlined, though its inland limit has not been determined, includes a diversity of rocks. Along the coast where the observations were in more detail three formations are differentiated, as follows: (1) A lower formation, consisting of slates, shales, and limestones, containing several coal beds, and yielding Paleozoic fossil plants. (2) Overlying the coal-bearing beds are black cherts, slates, shales, and cherty limestones containing corals and bivalve fossils, the most common being several species of Aviculopecten. (3) Above these beds is a great thickness of massive limestones, largely made up of coral interbedded with massive white cherts.

The shaly members of the series are usually intensely crumpled while the more massive beds present broad open folds complicated by frequent thrust faults, which make the stratigraphy difficult to decipher.

Lower formation.-The coal-bearing formation, which is the lowest, has been identified at three localities, as is shown on the geologic map: It is distinguished from the overlying formation by the presence of coal beds and of fossil plants in some of the black shales and clays. It is, therefore, essentially a fresh-water deposit. In one instance marine invertebrates have been found in such position as to suggest a possible interbedding of marine sediments with the fresh-water deposits, but as this relation may be due to the infolding of some of the overlying formations it can not be accepted as conclusive evidence. The beds are usually thin and the formation as a whole is softer than the overlying rocks. For this reason it has been more deeply eroded, so that it forms the bed rock of the indented portions of the coast and determines the positions of some of the valleys.

$a$ Collier, A. J., The gold placer deposits of Seward Peninsula. (In preparation.)

bSpurr, J. E., Geology of the Yukon gold district, Alaska: Eighteenth Ann. Rept. U. S. Geol. Survey, pt. 3, pp. 155-169.

Collier, A.J., Coal resources of the Yukon: Bull. U. S. Geol. Survey No. 218, pp. 15, 16.

o Prindle, L. M., and Hess, F. L., The Rampart gold placer region: Buil. U. S. Geol. Survey No. 280, pp. 17-21.

d Schrader, F. C., Reconnaissance in northern Alaska: Prof. Paper U. S. Geol. Survey No. 20, 1904, pp. 62-67. 


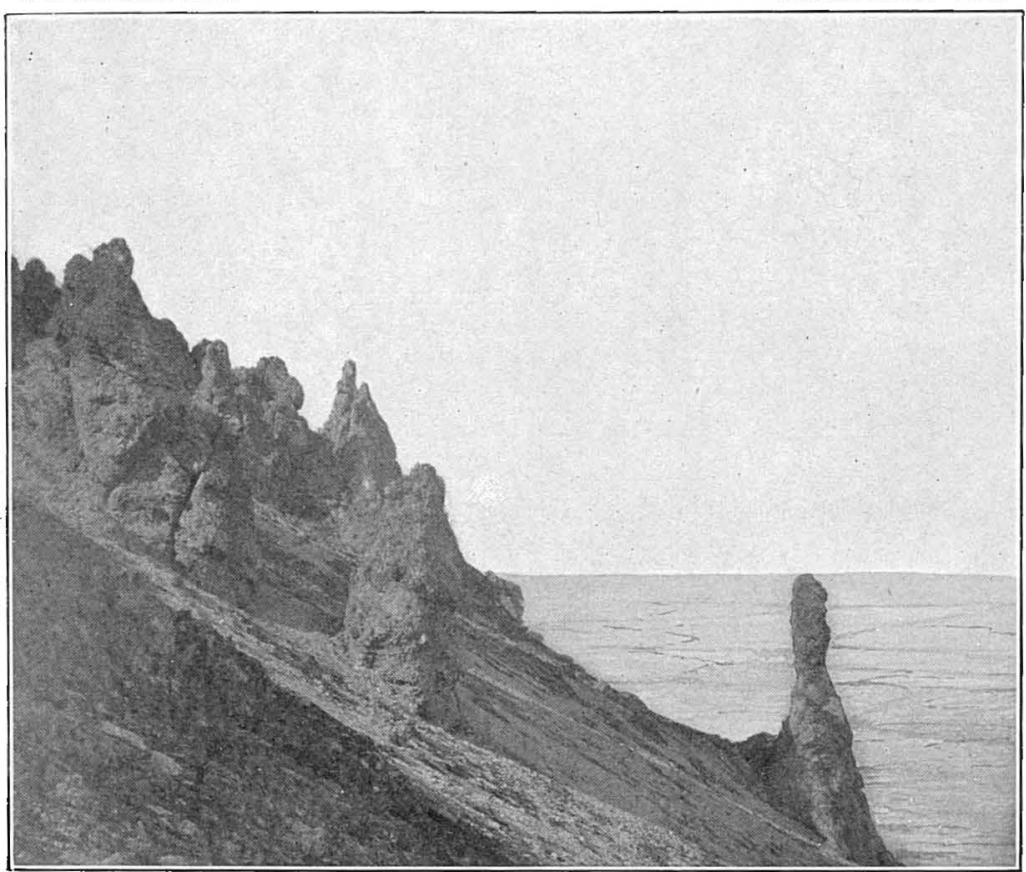

A. OUTCROPS OF BRECCIATED CHERTY LIMESTONE ON NORTH SLOPE OF MOUNTAIN AT CAPE LISBURNE.

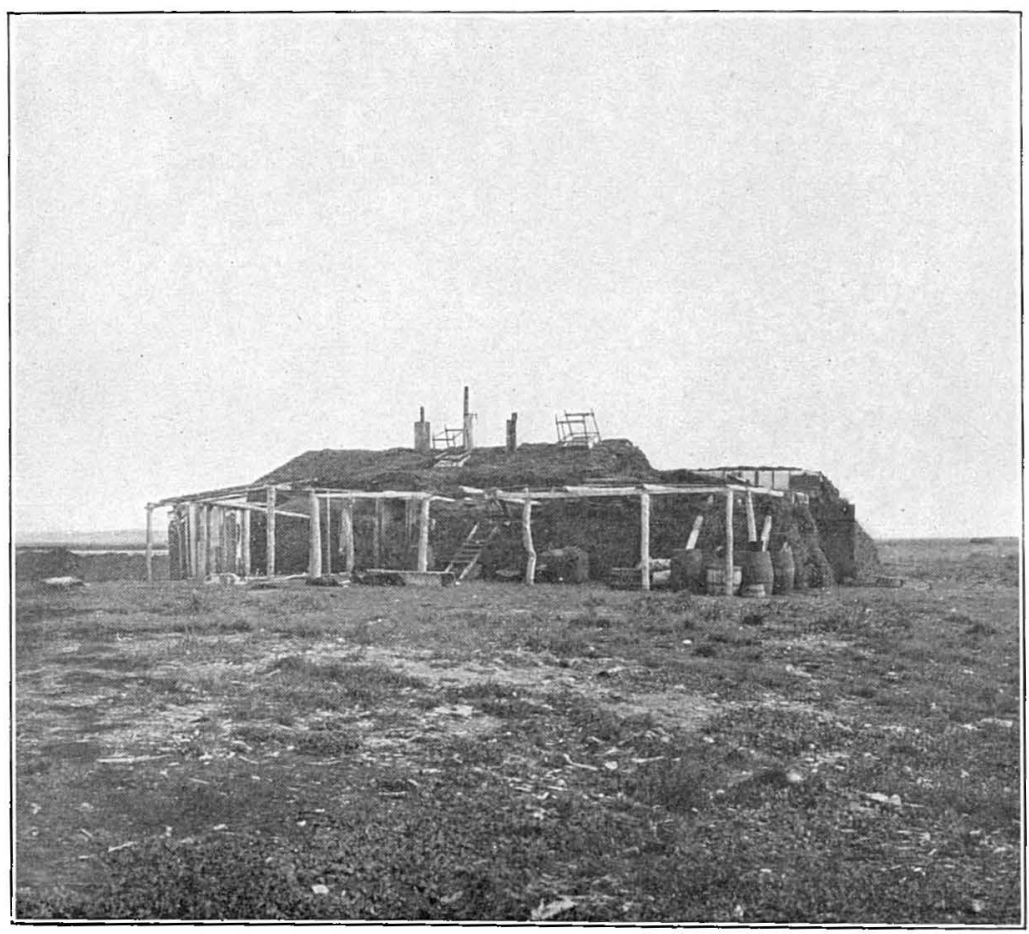

B. WHALING STATION AT JABBERTOWN, ON POINT HOPE PENINSULA. 

The structure in most cases consists of an intricate system of folding with faulting along the contact with the underlying and overlying formations. On the south side of Cape Dyer the coal-bearing formation seems to rest conformably on the sandstones which form the cape, while it is overthrust by the same sandstone at the Ears, about 2 miles south of Cape Dyer (see fig. 2). Between these two points the formation, which is almost continuously exposed, is closely folded, as is shown in fig. 3.

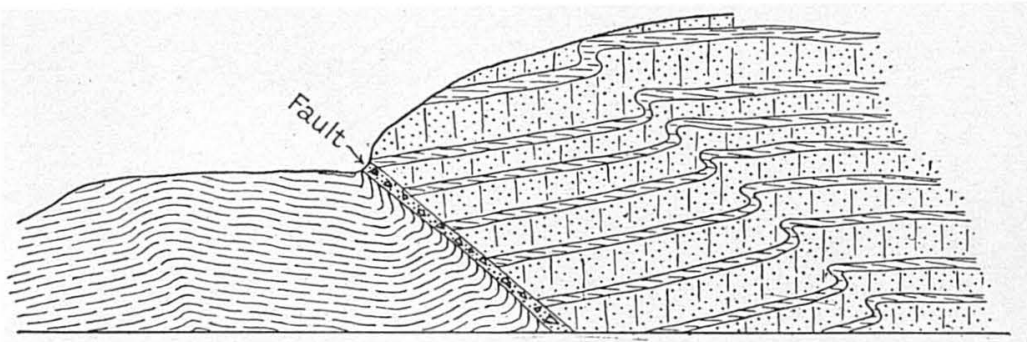

Fig. 2.-Thrust fault at the contact of Carboniferous and pre-Carboniferous rocks south of Cape Dyer.

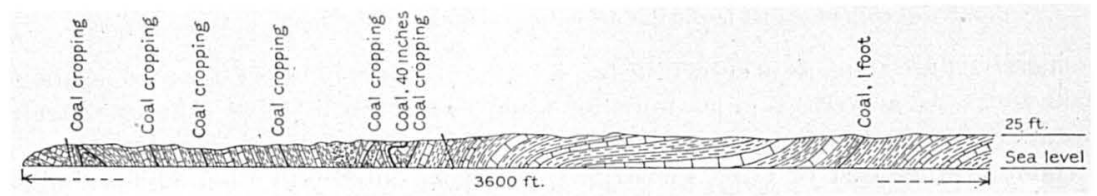

Frg. 3.-Section of Carboniferous coal formation between Cape Dyer and the Ears.

Between Cape Lewis and Cape Dyer the exposures are not continuous, but the structure seems to be more simple. The formation appears to rest conformably on the Devonian (P) sandstone of Cape Dyer and to be conformably overlain by the marine Carboniferous formations of Cape Lewis. The relation of the coal-bearing formation to the overlying rocks, as it appears at this point, is shown in fig. 4.

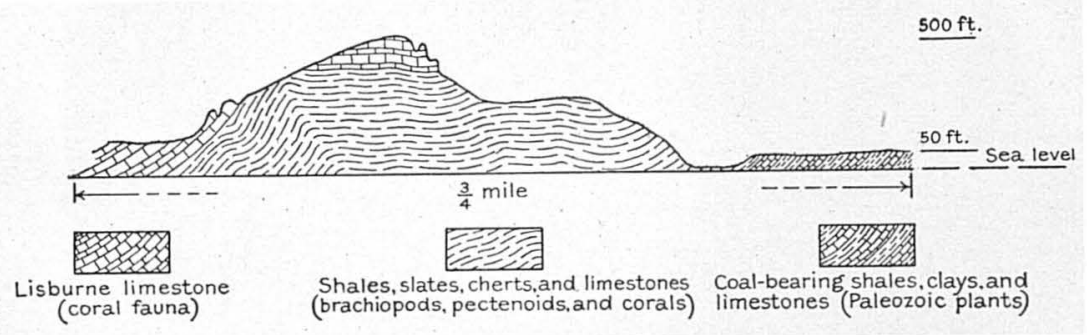

Fig. 4.-Sketch showing stratigraphic relations of the Carboniferous formations south of Cape Lewis.

Four miles south of Cape Lisburne the formation is again exposed. It is closely folded, the coal beds are sheared, and the massive limestone is thrust over it at the contact, as is shown in fig. 5 .

Middle formation.-The middle formation of the Carboniferous series has also been identified at three localities along the coast. It consists of thinly bedded black slates, shales, cherts, and cherty limestones, and is distinguished from the lower formation, which it resembles in general appearance, by the absence of coal beds or fossil flora of any kind, and from the upper formation of the series, first by its lithologic character and second by its fauna, which consists principally of brachiopods and mollusks, while that of the upper consists principally of corals. In general the 
formation is harder than the coal-bearing formation, and for this reason the topography produced by it is more rugged. Like the coal-bearing formation it is rather intensely folded, and faulting has usually occurred along its contacts with the massive limestones which overlie it. At the locality south of Cape Lewis it seems to rest conformably on the coal-bearing formation and to be overlain conformably by

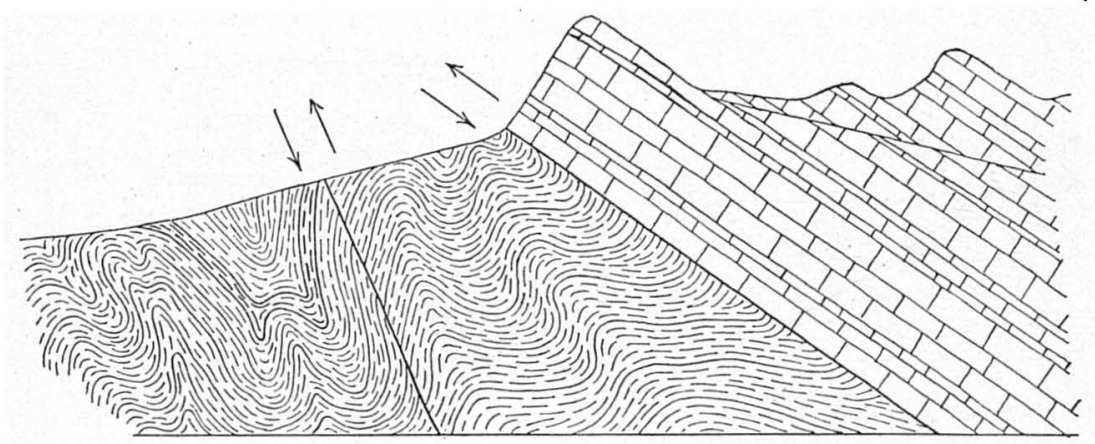

FIG..5.-Sketch of thrust faults in Carboniferous rocks 6 miles north of Cape Lewis.

the massive limestone, as is shown in fig. 4. Its thickness here is estimated at about 1,000 feet. At a point 4 miles north of Cape Lewis the massive limestone again appears to overlie it conformahly, but the coal-bearing formation is not exposed.

About 2 miles east of Cape Lisburne these rocks outcrop in a belt about 2 miles

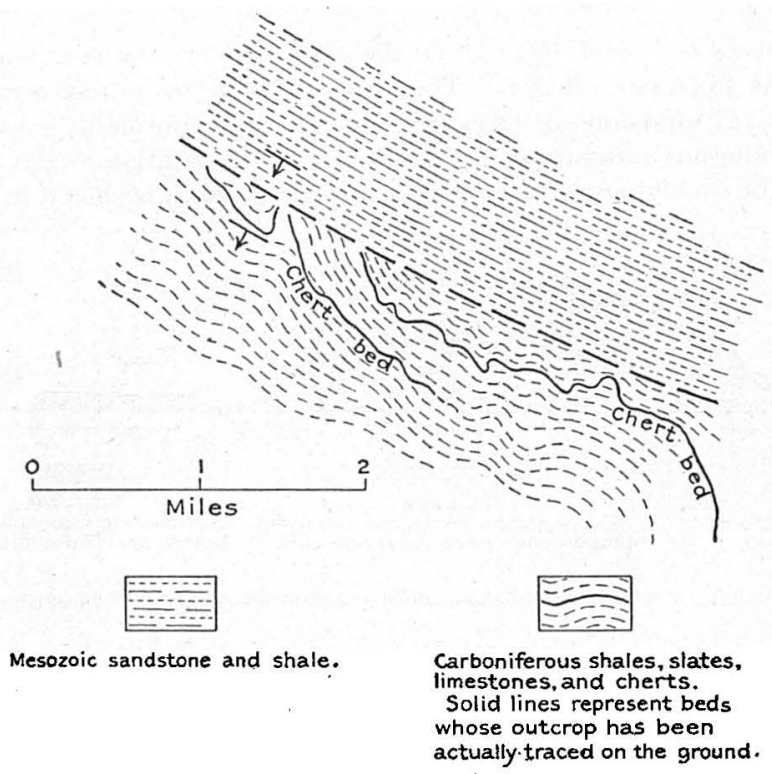

Fig. 6.-Ground plan of outcrops adjoining the probable fault contact between the Carboniferous and Mesozoic formations 3 miles east of Cape Lisburne.

wide extending southeast to the limit of this investigation. The massive limestone which forms the cliffs at Cape Lisburne seems to overlie them, but along the poorly exposed contact there is brecciation and other evidences of faulting. The slate and chert area here is marked by low hills and valleys, above which the massive lime- 


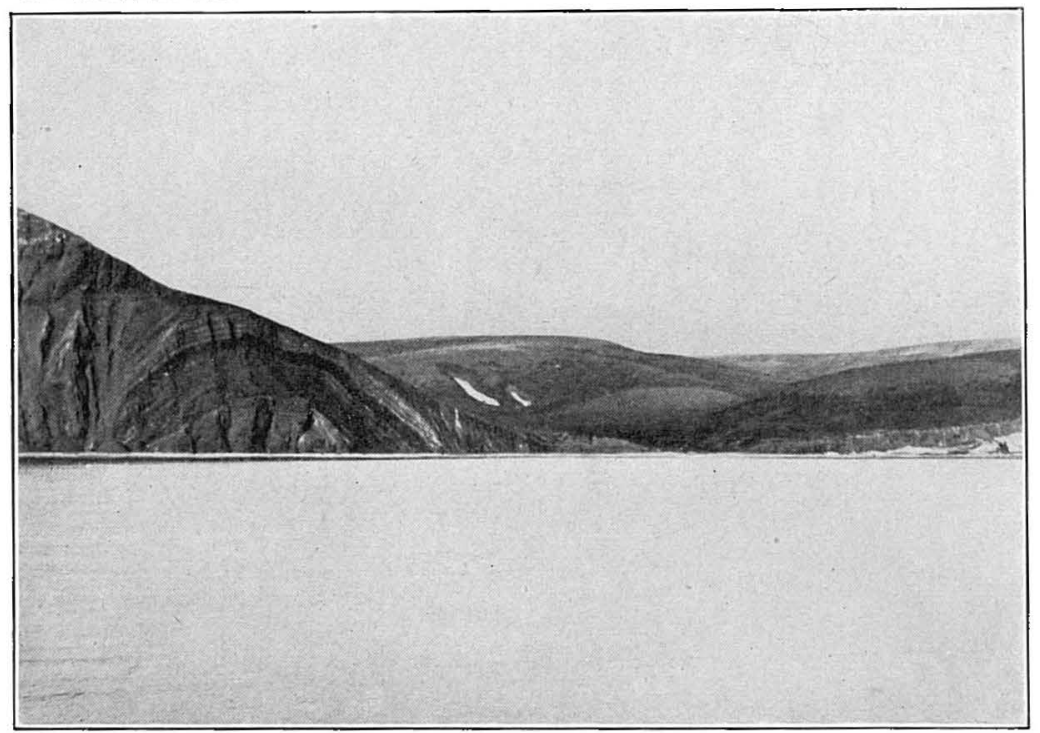

A. AGATE ROCK, CAPE THOMPSON.

Photograph by Doctor Call, surgeon of U. S. revenue cutter Thetis.

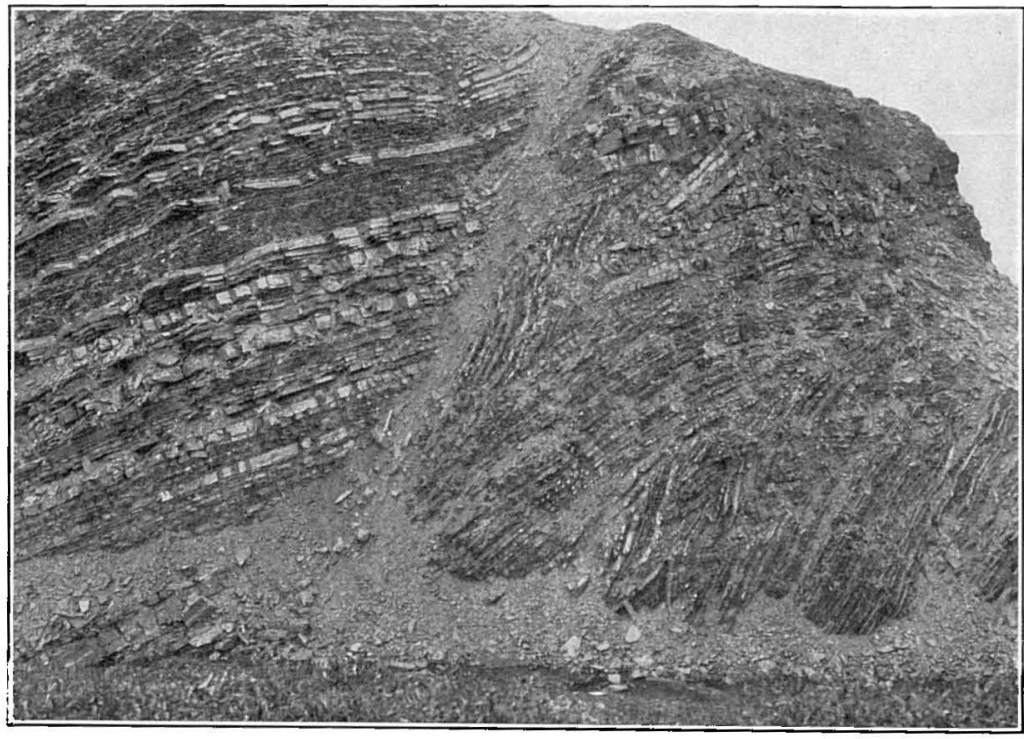

B. FOLDED BEDS AND THRUST FAULT IN THE UPPER MEMBER OF THE MESOZOIC SERIES 5 MILES EAST OF CAPE LISBURNE. 

stone mountains rise abruptly to an elevation of about 1,000 feet. The base of this mountain extends in a nearly straight line, which suggests a fault escarpment. In this area the sinuous outcrops of the cherty beds (see fig. 6), which can be traced for considerable distances, indicate that the formation is intensely crumpled and probably closely folded.

Lisburne formation. - The upper member of this series was called the Lisburne $a$ formation by Schrader, who correlated it with the massive limestones at the head of Anaktuvuk River. It is typically exposed near Cape Lisburne, from which it takes its name, but it is also well exposed at many other localities along the coast and inland, since it is the thickest as well as the hardest formation of the series and its outcrops form the highest elevations of the Lisburne IHills. The formation consists of massive thick-bedded limestones, massive white cherts, and occasional thinner beds of black slate or shale, and is distinguished from the underlying Carboniferous formations by its lithologic character and its fauna, which consists mainly of corals. The contact relation of the upper to the middle formation of the series is conformable in an exposure sonth of Cape Lewis, as is shown in fig. 4, but in most of the other places where the contact is exposed faulting has occurred. The thickness exposed at Cape Lewis and also south of Cape Lisburne can not be regarded as less than 2,000 feet and may be much greater. Owing to the complicated structure and the hastiness of the field examination an exact determination of the thickness exposed was impossible. The structure consists of open folds and thrust faults. The intense folding which characterizes the two underlying formations is wanting. Fault breccia with interstitial calcite occurs near Cape Lisburne. It resembles coarse-grained por-

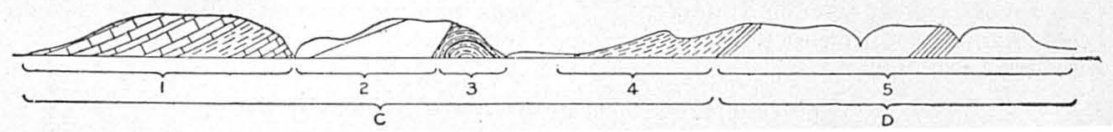

Fia. 7.-Sketch of the section exposed in the cliffs at Cape Thompson.

phyry, for which it has probably been mistaken, and perhaps has given rise to the reports of porphyry dikes near Cape Lisburne. On the north side of Cape Lisburne and also at Cape Lewis the limestone weathers into jagged pinnacles, which are shown in Pl. III, $A$.

At Cape Thompson, a locality 35 miles southeast of Point Hope, not visited by the writer, the presence of the upper two of these formations is indicated by fossils $b$ which have been collected by other expeditions while the coal-bearing formation is reported by prospectors and other residents of the region. The geologic section exposed in the cliffs was sketched from the deck of the steamship Corwin at a distance of about 3 miles, and is shown in fig. 7. The arch in the center of fig. 7, which is called "Agate Rock," is shown in greater detail in a photograph, Pl. IV, $A$, for which the writer is indebted to Doctor Call, surgeon of the United States revenue cutter Thetis.

A geologic section included in the notes of Messrs. Belcher and Collie ${ }^{c}$ of the Beechey expedition shows a relation of the two upper formations similar to that observed in several places near Cape Lisburne. The occurrence of the rocks along Kukpuk River is indicated by abundant fossils found in the gravels, though the writer did not ascend the river far enough to find the rocks in place.

$a$ Schrader, F. C., op. cit., pp. 62-67.

b Schuchert, Charles, Report on Paleozoic fossils from Alaska: Seventeenth Ann. Rept. U. S. Geol. Survey, pt. 1, 1896, pp. 898-899.

Girty, Geo. H., Report on fossil invertebrates collected by the Collier party in the Cape Lisburne region, Alaska: pp. 22-26 of this bulletin.

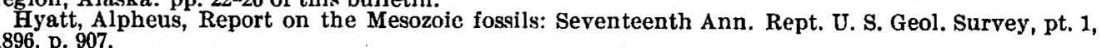
1896, p. 907.

c Zoology of Captain Beechey's voyage, London, Bohm, 1839, p. 173. 
Several collections of fossils; made from these rocks as exposed at Capes Lisburne and Thompson previous to 1904, have given rise to various opinions as to their geologic age. The fossils collected from Cape Thompson by Belcher and Collie were determined by Professor Buckland $a$ as Carboniferous, similar to the limestone of Derbyshire.

The collections of Fisher and Kupreanoff from Cape Lisburne were regarded by Grewingk $b$ as in part Upper Silurian. A collection made by Dumars and Maddren in 1900 was regarded by Schuchert as of Middle Devonian age. $c$ A small collection of fossil plants from the same locality was regarded by David Whited as indicating either an Upper Devonian or Lower Carboniferous age.

A large collection of fossils, including both plants and invertebrates, from the various formations described above was made in the course of the present investigation and may be regarded as conclusive evidence that the whole series, including the three formations described, is Lower Carboniferous and should be correlated with the Mississippian series of the Carboniferous system. Reports on these collections were made by David White and George H. Girty, and are subjoined.

Report on Fossil Plants.

BY DAVID WHITE.

The material, consisting almost exclusively of dark, gnarly, and slightly micaceous fire elay, comes under two field labels and comprises fragments of the following-named plants:

Lot $\$ 553$, one-half mile south of Cápe Dyer; field number, \& $A C \$ S$.

Sphenopteris frigida $\mathrm{Hr}$.

Calamarian fragment (Asterophyllites?). Lepidodendron spetsbergense Nath.

Lepidostrobus n. sp.

Stigmaria verrucosa (Mart.) Mill.

Samaropsis spetsbergensis (Hr.) Nath. ? (obscure example).

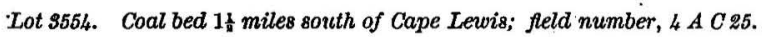

Cođonophyton sp.

Dictyoxylon sp.

Lepidodendron herri Nath.

L. veltheimianum acuminatum Goepp.

Barinophyton sp.?

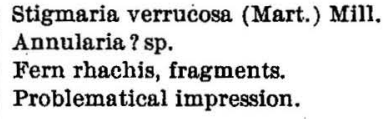

These fossil plants are evidently of Carboniferous age. Owing to the marked scarcity of flicate elements the testimony of the collection is less direct as to precise age than might otherwise be the case. However, from the evidence in hand I am forced to conclude that the plant-bearing terrane is Mississippian, and it appears probable that it is referable to the lower portion of the Mississippian. The flora, especially that of lot 3554 , is very closely related to that from Bell Sound and Klass-Billen Bay in Spitzbergen. It seems to be slightly younger than the Ursa flora.

REPORT ON FOSSIL INVERTEBRATES.

BY GEORGE H. GIRTY.

The Carboniferous faunas of Alaska are diferent from those of central and eastern United States, and comprise either new species or ones described in more or less casual papers upon Russian or Asiatic paleontology. The paleontologist, therefore, labors under some difficulty in reporting upon such collections, since it is not only often impossible to give lists with specific determinations, but even faunal comparisons and correlations are attended with uncertainty.

The following lists embrace the species which have been discriminated at the different stations where collections were made:

a Schuchert, Charles, Report on Paleozoic fossils from Alaska: Seventeenth Ann. Rept. U. S. Geol. Survey, pt. 1, pp. 898-900. Zoology of Captain Beechey's voyage, London, Bohn, 1839, pp. 17i-174.

b Op. cit. pp., 898-900.

c Schrader, F. C., Reconnaissance in northern Alaska: Prof. Paper U.S. Geol. Survey No. 20, 1904, p. 66.

$d$ Schrader, F. C., op. cit., p. 114 . 


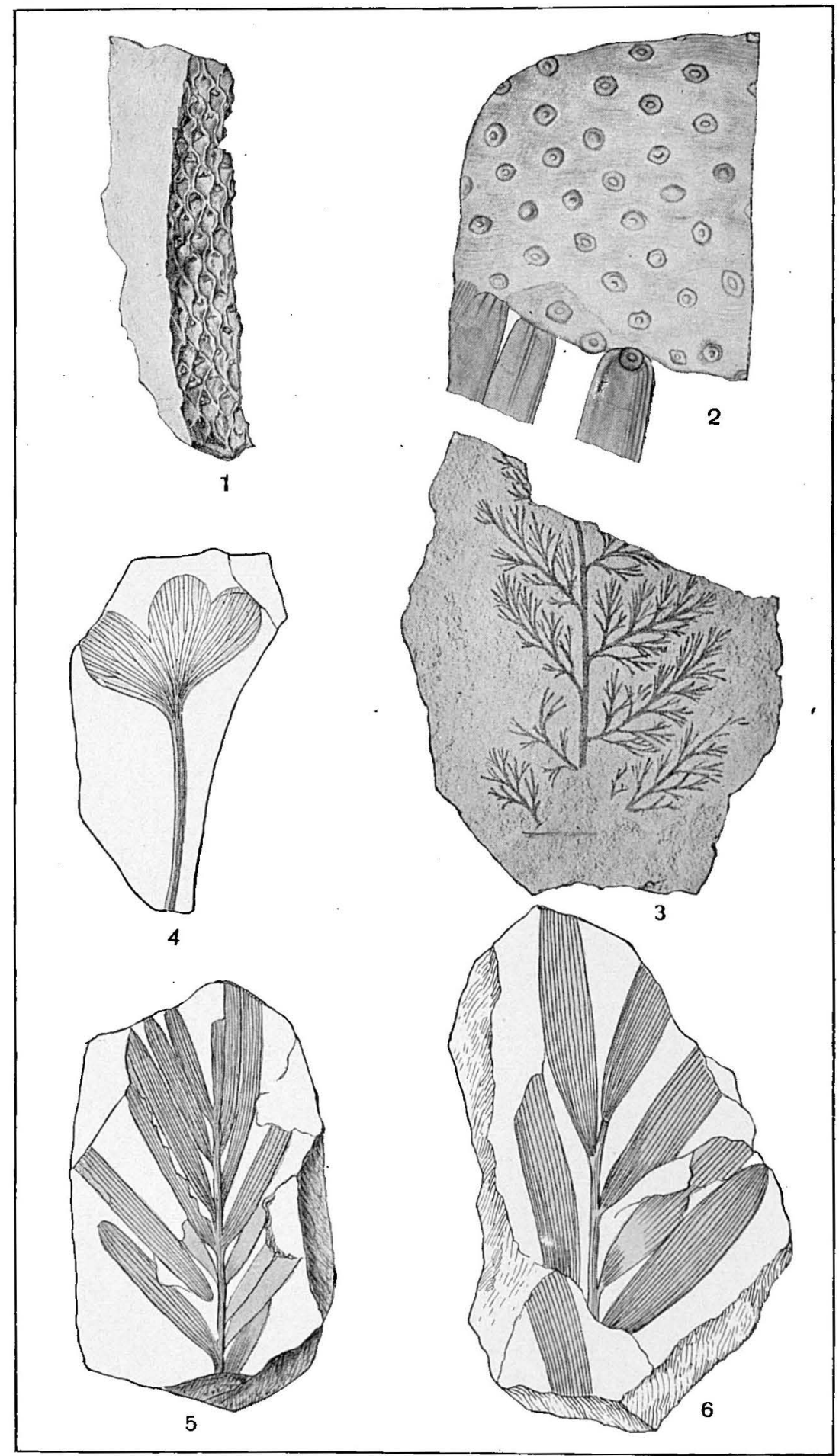

PALEOZOIC AND MESOZOIC PLANTS FROM THE CAPE LISBURNE REGION, ALASKA.

Carboniferous: 1, Lepidodendron spetsbergense. 2, Stigmaria verrucosa. 3, Sphenopteris frigida. Jurassic: 4, Ginkgo Huttoni. 5, Podozamites angustifolius. 6, Podozamites lanceolatus. Figs. 1 and 3 , after Nathorst; figs. 2, 4, 5, and 6, after Heer. 

Station 4 A C 14, s miles southeast of Cape Lisburne.

Syringopora sp. a.

Lithostrotion sp. a var.

Lithostrotion sp. b.

Lithostrotion junceum.

\section{Spònge ?}

Zaphrentis sp.

Productella sp.

Martinia sp.

Reticularia sp.

Productus ? sp.

Productella ? sp.

Aviculopecten, several sp.

Station 4 A C 19, 31 miles south-southeast of Wevok.

Lithostrotion sp. a ?

Lonsdaleia? sp. a.

Diphyphyllum sp. a.

Station 4 A C 15, 1: miles southeast of Wevok.

I Aviculopecten $2 \mathrm{sp}$.

Station $4 A C 16$, 2 miles southeast of Wevok.

\author{
Aviculopecten ? sp. \\ Euomphalus sp. \\ Ostracod. \\ Proetus sp.
}

Station 4 A C 17, 3 miles southeast of Wevok.

$$
\mid \begin{aligned}
& \text { Dentalium ? sp. } \\
& \text { Goniatites sp. }
\end{aligned}
$$

Station 4 A C 18, 31 miles southeast of Wevok.

1 Nucula ? sp.
Lithostrotion portlocki var.

Cleiothyris aff. C. roissyi.

| Lithostrotion portlocki.

Station 4 A C21, 3 miles east-8outheast from Wevok.

Aviculopecten sp.

Station 4 A C 22, 3 miles southeust of Cape Lewis.

Zaphrentis sp. a.

Lithostrotion portlocki var.

Leptæna rhomboidalis.

Productus, semireticulatus group.

Spirifer aff. S. mosquensis. Reticularia aff. R. lineata. Cypricardinia ? sp. Sphenotus? sp.

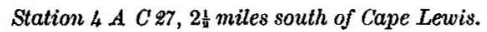

Zaphrentis sp. a.

Cystophyllum ? sp.

Lithostrotion portlocki var.

Diphyphyllum sp. b ?

Productus, punetrtus group.

Productus sp. $b$.

Station 4 A $C 28$, 2 miles east of Cape Lewrs.

Syringopora ? sp. c.

Lithostrotion sp. a.

Lithostrotion sp. c.

Lithostrotion junceum.

$$
\begin{aligned}
& \text { Lithostrotion irregulare. } \\
& \text { Crinoidal fragments. } \\
& \text { Spirifer aff. S. mosquensis. }
\end{aligned}
$$

Station 4 A $C$ 29, 1 mile east of Cape Lewis.

Zaphrentis sp. a.

Lithostrotion sp. b.

Lithostrotion irregulare.

\author{
Diphyphyllum sp. a. \\ Fenestella sp. \\ Spirifer aff. S. mosquensis.
}

Station 4 A C 53, 15 miles southeast from Cape Chibukak, St. Laurence Island.

Aviculopecten sp. (Same at 4 A C 18.)

Aviculopecten sp.

Station \& A C81, 4 miles southeast from Wevok.

Station 4 A $W 27$, 4 miles east-southeast from Cape Lisburne.

Syringopora sp. a.

Syringopora sp. b.

Lithostrotion sp. a var.

Lithostrotion sp. c.

Lithostrotion portlocki ?

Lithostrotion irregulare.

Lithostrotion? sp. ind.
Zaphrentis sp. a.

Small ind. corals.

Productus, semireticulatus group.

Productus, punctatus group.

Productus sp. $b$.

Rhynchonella sp. 
Zaphrentis sp. $\mathbf{n}$.

I.ithostrotion portlocki.

Syringopora sp. a.

Stenopora sp.

Undeterminable.
Lithostrotion junceum.

Fenestella sp.

Station 4 A W29, 1 mile southeast of Wevok.

\author{
Productus, semireticulatus group. \\ Productus giganteus? \\ Rhynchonella sp. \\ Aviculopecten sp. \\ Bellerophon? sp.
}

Station 4 A W 30, cobblestone in creek east of Wevok.

1 Polypora sp.

Station 4 A W 32.

Station 4 A W SB, 2 to $3 \frac{1}{2}$ miles southeast of Wevok.

Aviculopecten, several sp. Nucula? sp.

Pararca? sp.

Station 4 A W S4.

Aviculopecten sp.

Nucula? sp.

Pararca? sp.

Station 4 A W \$5, 1 mile south of Cape Lewis.

Zaphrentis sp. a.

Syringopora sp. b.

Lithostrotion irregulare.

Stenopora sp.

Fistulipora aff. F. barberi.

Fenestella 3 or $4 \mathrm{sp}$.

Station 4 A W s6, south slope of Cape Lewis Mountain.

Syringopora sp. a.

Lithostrotion sp. a.

Lithostrotion irregulare.

- Fenestella sp.

Station 4 A W 57 , \& miles north of Cape Lewis.

Fucoid.

Lithostrotion sp. a var.

Lithostrotion sp. $\mathrm{b}$.

Lithostrotion portlocki var.

Syringopora sp. a.

\author{
Fenestella several sp. \\ Rhombopora sp. \\ Spirifer aff. S. mosquensis. \\ Cleiothyris aff. C. roissyi. \\ Pleurotomaria sp.
}

Station 4 A W $98,2 \frac{1}{4}$ miles north of Cape Lewis.

Aviculopecten, several sp.

| Nucula? sp.

Station 4 A W S9, 3 miles north of Cape Lewis.

Orthotetes? sp.

1 Cleiothyris aff. C. roissyi.

Station \& A W 40, 4 miles north of Cape Lewis.

Fucoid.

Lithostrotion sp. a var.

Lithostrotion irregulare. Spirifer sp.

Station \& A W 44, 6 miles,north of Cape Lewis.

Zaphrentis sp. a.

I Pleurotomaria sp.

Aviculopecten sp.

Station $4 A . W 45$, cobblestone on point of spit.

Station 4 A W 46 , gravels of Kukpuk River.

Lithostrotion sp. a var.

Lithostrotion sp. b.

Lithostrotion sp. c.

Lithostrotion irregulare.

Lithostrotion portlocki var.

Iiphyphyllum sp. e.

Southeast of Wevok.

Aviculopecten sp.

I Pararca? sp.

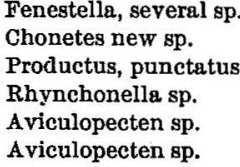


Mr. Collier tells me that the stratigraphic relations of the beds are best shown at Cape Lewis, and that in this region two formations can be discriminated, a massive limestone overlying a series of thin limestones, shaly beds, and coals. If the occurrence of fossils at this point be used as a temporary standard, it appears that two more or less different faunas are presented, that from the massive limestone (represented in lots $4 \mathrm{~A} \mathrm{C} 28,4 \mathrm{~A} \mathrm{~W} 36,4 \mathrm{~A} \mathrm{~W} 37,4 \mathrm{~A} \mathrm{~W} 40$, and $4 \mathrm{~A} \mathrm{~W} 44$ ), consisting chiefly of corals belonging to the genera Lithostrotion, Diphyphyllum, Zaphrentis, and Syringopora, and that from the thinner beds (shown in lots $4 \mathrm{~A} \mathrm{C} 22,4 \mathrm{~A} \mathrm{C} 27,4 \mathrm{~A} \mathrm{~W} 35$, and $4 \mathrm{~A} \mathrm{~W} 39$ ) containing a more or less abundant representation of corals, but with numerous brachiopods and other forms. It should be remarked, however, that the corals of the soft beds are essentially the same as those of the massive limestone, while the brachiopods of the latter are essentially those of the soft beds, so that the two faunas are closely related.

As to the geologic age of these faunas I feel little hesitation in referring them to the Lower Carboniferous. The presence of Producti of the punctatus and scmircticulatus groups, and the abundance of the genus Lithostrotion clearly determine the horizon as post-Devonian. The genus Lithostrotion is especially characteristic of the Lower Carboniferous, and in the Alnskan fauna occur several forms seemingly identical with species found in the Mountain limestone of England and the Productus giganteus zone of European Russia. The age, therefore, even of the heavy limestone, can safely be called Lower, instead of Upper, Carboniferous. Lithostrotion occurs in the underlying thin beds as weil, and because these contain the species Leptana rhomboidalis, whose range in the Mississippi Valley terminates with the Burlington epoch, I would be disposed to assign the beds of this division to a positiun low down in the Mississippian series.

An earlier collection from the same region, obtained through Mr. Schrader, was identified by Mr. Schuchert as Devonian; but since examining the later collections he agrees with my determination as Carboniferous. The earlier collection contains the following species :

Zaphrentis sp. a?

Zaphrentis sp. b.

Syringopora sp. a.

Syringopora sp. b.

Syringopora sp. c.

Lithostrotion sp. a.

Lithostrotion sp. $d$ var.

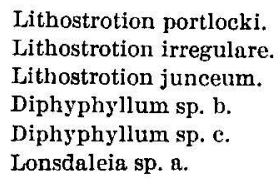

Lithostrotion portlocki.

Lithostrotion irregulare. Lithostrotion junceum.

Diphyphyllum sp. b.

Diphyphyllum sp. c.

Lonsdaleia sp. a.

And it is clear that if the faunal distinctions indicated by the more recent specimens bold good the fauna is unquestionably that of the massive limestone, rather than of the underlying softer, series.

In the vicinity of Cape Lisburne itself a group of collections was made which clearly refresents the same horizon as that from which the Cape Lewis faunas were obtained. Here belong the following : $4 \mathrm{~A} \mathrm{C} 14,4 \mathrm{~A} \mathrm{C} 19,4 \mathrm{~A} \mathrm{~W} 27,4 \mathrm{~A} \mathrm{~W} 29,4 \mathrm{~A} \mathrm{~W} 44$, and $4 \mathrm{~A}$ W 46 . Several of these clearly represent the fauna of the massive limestone. In one or two instances there may be some question as to whether the faunas of the softer series are not represented.

In this same region a series of collections was obtained, representing a fauna not yet collected at Cape Lewis. In this group belong the following lots: Southeast of Wevok, $4 \mathrm{~A} \mathrm{C} \mathrm{15,4} \mathrm{A} \mathrm{U} \mathrm{18,} 4$ A C 21,

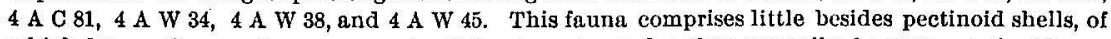
which four or five species are present. It has been treated rather cursorily, because pectinoids are not good for correlation and age determination, since the number of species described is very great and it is seldom possible among Paleozic specimens to be really certain of the true generic position. I may say, however, that the types represented are such as are found in the United States in the Devonian and Lower Carboniferous. As the strata from which the present material was obtained, at one place at least, appear to be implicated with the softer beds near Cape Lewis, this horizon can pretty safely be assigned to a place early in the Lower Carboniferous. I may add that it is not uncommon to find bands filled with shells of the Pccten group to the exclusion of almost every other type. In the present case at some points were found in association a small smooth shell and a large vaulred one with radial ribs, similar to Pararca, the generic position of neither of which has been ascertained.

A small collection made several years ago at Cape Thompson (at one time identified as Mesozoic), a and a specimen from St. Lawrence Island (4 A C 53), though rather scanty evidence, as they show what apparently is the same species in the same sort of matrix, can with a good degree of probability be correlated with the beds about Cape Lisburne.

In addition to the faunal groups already discriminated, iour species stand more or less clearly apart, although not connected with one another. They are $4 \mathrm{~A} \mathrm{C16,4} \mathrm{A} \mathrm{C} 17,4 \mathrm{AW} 30$, and $4 \mathrm{AW} 32$ These, $\mathrm{I}$ understand, are stratigraphically related to the softer beds of the Cape Lewis section, and there is nothing in the faunas to contradict such an assignment.

The corals which constitute so large a portion of the faunas in these collections have been studied with considerable care, but as they are $\Omega$ difficult group, and as they can not be satisfactorily deter-

a Hyatt, Alpheus, Report on Mesozoic fossils: Seventeenth Ann. Rept. U. S. Geol. Survey, pt. 1, 1896, p. 907. 
mined without the preparation of thin sections, my identifications must be considered to be of a somewhat preliminary character.

Every large collection of well-preserved fossils serves as a means of grouping together collections smaller in scope and those in which the preservation is inferior. Besides the material immediately referred to me a considerable number of collections were examined in order to ascertain if possible the distribution of the Cape Lisburne faunas. One of the best instances, and one with which I was already familiar, is an excellent collection made by Mr. Fred E. Wright on North Passage Peninsula, South Iyoukeen Cove, Chichagof Island. Another coliection was that made by Mr. Collier in 1903 near Cape Mountain ( 3 A C 136) a These fossils have been so altered that the absolute identification of the species is in most cases impossible, but I feel little doubt that the horizon will prove to be that of the Lisburne group. Very probably the same fauna was collected by Mr. Schrader $b$ on John and Anaktuvuk rivers (lots 455, 496, 498, 499, 501, 523, 524, and 533), and also from pebbles in Chandlar

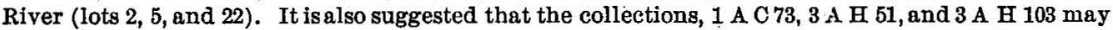
belong to the same fauna, but the suggestion is made only tentatively, for the evidence is imperfect.

Other Carboniferous areas in Alaska. - The rocks of the Carboniferous system, including its three more important divisions, are extensively represented in other districts of Alaska, where they are usually characterized by more or less massive limestones interbedded with other marine sediments. Except in the Cape Lisburne region, no fresh-water or coal-bearing beds have been definitely assigned to the Lower Carboniferous, nor, with this exception, have Carboniferous coal beds of economic value been found in America west of the one hundred and eightieth meridian. Rocks assigned to the Mississippian series occur at only a few widely scattered localities outside of the Cape Lisburne region. On the headwaters of John and Anaktuvuk rivers, about 400 miles east of Cape Lisburne, two Carboniferous formations, the Lisburne and the Fickett, comprising a thickness of several thousand feet, have been identified. $c$ The Fickett, however, is a very ill-defined subdivision, including both metamorphic and unaltered rocks. Of these the Lisburne formation can be definitely correlated with the formation of the same name in the Cape Lisburne region, while the Fickett group may in part represent a younger horizon, since from the evidence in hand it can not now be correlated with either of the formations described above.

At the western extremity of Seward Peninsula near Cape Prince of Wales there are some highly crystallized limestones and interbedded slates which may be correlated with a reasonable degree of certainty with the Lisburne limestones, $d$ and on St. Lawrence Island Oarboniferous rocks of the formation immediately below the Lisburne are probably represented, since drift material containing fossils of this horizon has been obtained by the writer on the island at some distance from the sea, though the rocks in place have not yet been located.

Fossils of the Lisburne horizon were also obtained last summer on Chichagof Island, southeastern Alaska $e$, from a limestone formation which is so intensely folded that its stratigraphic relations to the Upper Carboniferous, which is also represented, could not be determined.

The Carboniferous rocks of the Yukon basin are apparently all younger than the Mississippian. In this province Carboniferous fossils (probably Pennsylvanian) occur on the Yukon a short distance below Eagle $f$ and in a limestone area south of the Yukon Flats.g

a Collier, A. J., Tin deposits of the York region, Alaska: Bull. U. S. Geol. Survey No. 229, 1904, p. 14. o Schrader, F.'C., Reconnaissance in northern Alaska in 1901: Prof. Paper U. S. Geol. Survey No. 20 , 1904, pp. 64-65.

c Schrader, F. C., op. cit., pp. 62-72.

$d$ Brooks, A. H., and others, Reconnaissance in the Cape Nome and Norton Bay regions, Alaska: Special publication, U. S. Geol. Survey, 1901, p. 133.

Collier, A. J., Reconnaissance of the northwestern portion of Seward Peninsula: Prof. Paper U. $\mathbf{S}$. Geol. Survey Ño. 2, 1902, p. 16.

Tin deposits of the York region, Alaska: Bull. U. S. Geol. Survey No. 229, 1904, p. 14

eGirty, G. H., Report on the fossil invertebrates collected by the Collier party in the Cape Lisburne region, Alaska, included in this bulletin.

$f$ Collier, A. J.. Coal resources of the Yukon: Buli. U. S. Geol. Survey No. 218, pp. 15-16.

$g$ Prindle, L. M., and Hess, F.L., The Rampart gold placer region, Alaska: Bull. U. S. Geol. Survey No. 280 . 
The Permian series is represented by massive limestones and other sediments $a$ near Nation River on the Yukon, and a similar formation has been identified on the upper basin of White River. $b$

An Upper Carboniferous series in the northern part of the Copper River basin consists of a medium to heavy-bedded limestone, which may represent a basal portion of a calcareous terrane that continues upward to the horizon of the Permian beds. $c$

In southeastern Alaska and adjacent parts of British Columbia massive crystalline limestones, which have been referred to the Carboniferous in general and whose stratigraphic relations are difficult to decipher, are widely distributed. $d$

None of the Carboniferous formations younger than Mississippian occur in the Cape Lisburne region, though if the assignment of a part of Schrader's Fickett group to an upper horizon is correct they may be reasonably expected at points farther inland and their absence along the coast may be attributed to erosion.

\section{MESOZOIC FORMATIONS.}

The Mesozoic rocks underlie the Arctic Slope region northeast of the Lisburne Hills. They can usually be readily distinguished by lithologic characters from the Paleozoic rocks, since they consist of practically unaltered sandstones, conglomerates, and shales and contain no beds of limestone or chert. Two formations, of which the older is coal bearing while the younger is destitute not only of coal but of fossils, have been recognized. (See geologic map, Pl. I.)

\section{CORIVIN FORMATION.}

The older of the Mesozoic formations, which takes its name from Corwin Bluff and the coal mines there located, is best exposed on the coast at a point 26 miles east of Cape Lisburne and thence extends northeast ward to Cape Beaufort, a distance of 40 miles, which is the limit of this investigation. It is known to occur again near Wainwright Inlet $e 100$ miles beyond Cape Beaufort, and there is some reason for the belief that it is continuous to that point. The southern boundary of the formation, as shown on the geologic map, extends in a southeasterly direction from the coast for about 12 miles, where it turns to the south as shown. Beyond this the inland extension of the formation has not been determined, though statements made by explorers and prospectors seem to indicate a probability of its occurring on the headwaters of the Chipp and in the upper Colville basin, 200 miles east of the type locality at Corwin Bluff.

No contact between the Corwin formation and the Carboniferous rocks described occurs within the limits of the area under investigation, though an unconformity is evident from certain beds of conglomerate containing pebbles derived from the Carboniferous. Lithologically the formation consists of rather thinly bedded shales, sandstones, conglomerates, and coal beds. Fossil plants occur in the shales wherever they have been closely examined. The shales which comprise the greater part of the formation vary in composition from greenish-brown calcareous to black carbonaceous beds and in texture from mudstones to fine-grained sandy shales. The sanclstones which occur at infrequent intervals through the formation, in beds usually less than 10 feet thick, are easily traceable over eroded areas, since theír outcrops rise in relief above the surrounding shales.

a Spurr, J. E., Geology of the Yukon gold district, Alaska: Eighteenth Ann. Rept. U. S. Geol. Sur-

vey, pt. 3, 1898, p. 170 .
Collier, A. J., Coal resources of the Yukon: Bull. U. S. Geol. Survey No. 218, 1903, pp. 15-16.

b Brooks, A. H., Reconnaissance from Pyramid Harbor to Eagle City: Twenty-first Ann. Rept. U. S. Geol. Survey, pt. 2,1900 , p. 359.

o Mendenhall, W. C., and Schrader, F. C., Mineral resources of the Mount Wrangell district: Prof. Paper U. S. Geol. Survey No. 15, 1903, p. 46.

dBrooks, A. H., The Ketchikan mining aistrict: Prof. Paper U. S. Geol. Survey No. 1, 1902, pP. 22-24.

e Schrader, F. C., Reconnaissance in northern Alaska in 1901: Prof. Paper U. S. Geol. Survey No. 20, 1904, pp. 73-74. 
The conglomerates are made up mainly of quartz and chert pebbles from one-half inch to 4 inches in diameter. The most definite bed of this kind, which is about 15 feet in thickness and reaches the coast at Corwin Bluff, forms a prominent ridge from 100 to 200 feet high. Its seaward end is shown in the photograph, Pl. II, $B$. This ridge, with the conglomerate of which it is composed, has been traced continuously to the southeast for about 15 miles (see Pl. VII). Since it extends in a nearly straight line and is not deeply covered by tundra growths, it is the usual route followed by the natives in traveling overland from Corwin Bluff to Pitmegea and Kukpowruk rivers, and is almost invariably indicated on maps drawn by them. On account of its persistence and the ease with which it can be traced and identified this conglomerate bed offers a definite key to the structure of the formation over a large area and indicates the absence of any extensive faults in the portion of the field shown on the map (Pl. VII).

The structure of the Corwin formation in general consists of several broad synclines and anticlines, as is shown on the geologic map and section, Pl. I. There is no evidence of faulting other than minor shearing movements parallel with the bedding planes.

The thickness of the strata exposed along the coast near Corwin Bluff is not less than 15,000 feet, as is shown in the stratigraphic column, Pl. IX, though the base of the formation is probably not shown. The formation throughout presents very little variation in lithologic character beyond the fact that in some portions of the section the shales are more carbonaceous while in others they are more calcareous. Throughout the section there is nearly the same proportion of sandy beds.

The conglomerate bed which terminates in Corwin Bluff seems to possess more distinct individuality than any other stratum examined, and it can usually be readily differentiated from other conglomeratic beds, which are neither well defined nor extensive.

Geologic notes on this formation and collections made by explorers previous to 1904 have given rise to a variety of opinions regarding its age. Mr. Collie, who first reported the presence of coal beds at Cape Beaufort, made notes and collections of fossils from which the age of the formation as exposed at Cape Beaufort was assumed by Doctor Buckland and others to be Carboniferous. $a$

The collections made by Henry D. Woolfe, who was in this region from 1885 to 1887, were examined by Lesquereux and Newberry, who regarded the age indicated as Neocomian. Professor Ward, in his enumeration of publications on Alaskan paleobotany, regarded the age indicated as Lower Cretaceous or possibly Upper Jurassic. $b$

Additional collections from Wainwright Inlet made by Schrader in 1901 were identified by Professor Fontaine and Professor Ward, who regarded the flora as not older than the oolitic of the Jurassic nor younger than the Lower Cretaceous and probably transitional between the two. The Corwin formation was therefore provisionally assigned by $\operatorname{Schrader}^{c}$ to the Jura-Cretaceous. A very much larger and in many respects more satisfactory collection from 19 localities, representing nearly the entire thickness of the formation, was obtained by the writer and his assistants during the last season. This collection has been examined and compared with the previous collections from the Cape Lisburne region by F. H. Knowlton, whose report is subjoined.

a Schuchert, Charles, Report on Paleozoic fossils from Alaska: Seventeenth Ann. Rept. U. S. Geol. Survey, pt. 1 , p. 900 .

b Dall, W. H., and Harris, G. D., Correlation papers-Neocene: Bull. U. S. Geol. Survey No. 84, p. 249. Dall, W. H., Report on coal and lignite in Alaska: Seventeenth Ann. Rept. U. S. Geol. Survey, pt. 1 ,
p. 900 .

Ward, Lester F., The geographical distribution of fossil plants: Eighth Ann. Rept. U. S. Geol. Survey, 1889, p. 926. c Schrader, F. C., Reconnaissance in northern Alaska in 1901: Prof. Paper U. S. Geol. Survey No. 20,
1904, p. 74. 
Report on Mesozolc Fossil Puants from Northwestern Alaska.

BY F. H. KYOWLTON.

From the time, about twenty years ago, when I handled the first collection of fossil plants from the Cape Lisburne region, I have been greatly interested in this flora, and have followed somewhat closely the results of its study. The present collection is in many respects tire best thus far obtained, being in general ample and especially rich in fruiting ferns, and thus permits the settlement of some questions of affinity that was before impossible. The combined previous material has recently passed through Professor Fontaine's hands, and by the courtesy of Professor Ward I have been granted access to his manuscript and the proof plates which are soon to be issued in his (Ward's) Status of the Mesozoic Floras of the United States, Second Paper. I have also had access to the original material, which is now the property of the United States National Museum. Without these collections and the manuscript and plates above mentioned my work on the present material would have been greatly increased, if not made impossible, although I am compelled to dissent from some of Professor Fontaine's conclusions, as will be set forth.

There are nineteen localities represented in this collection, all appurently in the vicinity of Corwin Bluff, Cape Lisburne region. Combined they yield the following fossil plants:

Mesozoic fossil plants from Cape Lisburne region, northwestern Alaska, submitted for determination by A. J. Collier.

1. Cladophlebis Huttoni (Dunk.). Font. Abundant.

2. Dicksonia n. sp.? Most abundent of all; finely fruiting.

3. Dicksonia Borejensis Zalessky. Single specimen.

4. Tæniopteris parvula Heer. Small fragments.

5. Equisetum sp. Single stem.

6. Podozamites lanceolatus lutifolius (Schenk) Heer. Many.

7. Podozamites? sp. A number of large leaflets.

8. Baiera palmata Heer. Two or three specimens.

9. Phœnicopsis angustifolia Heer. Several specimens.

10. Phœnicopsis speciosa Heer. Several specimens.

11. Pagiophyllum Kurrii (Pom.) Schimp. One or two fine specimens.

12. Stachyotaxus septentrionalis? (Ag.) Nath. One small example.

13. Taxites? subzamioides? Möller. Fragments.

14. Ginkgo Huttoni Font., n. var. Large number.

In my opinion these plants indicate a Jurassic age for the beds containing them, or at least are not younger than the Wealden. By eliminating the two f rms not specifically named and the two species not satisfactorily identified, we have ten of the fourteen forms sufficiently well determined to permit of their use in fixing the age. Of these no less than seven are common to the Jurassic of eastern Siberia, not to mention other parts of the world. Of the remaining three, one (Pagiophyllum Kiorrii) is found in the Lias of Bornholm, another (Cladophlebis Huttoni) in the Wealden of Hanover, and the last is what appears to be new species of Dicksonia. This is the most abundant form, being found at nearly all the localities, and among them are a number of large, fine, fruiting specimens which fix definitely its systematic position. It has not been found fruiting before, and sterile portions from the upper part of the frond were identified by Fontaine as Onychiopsis psilotoides, while lower portions were called Cladophlebis alata. This Onychiopsis psilotoides is found in the Wealden of England and elsewhere, and the Cladophlebis in the Potomac formation, and as both are quite abundant in the original collections, they were much relied upon by Fontaine to prove the JurassicCretaceous age of the Cape Lisburne beds. Mr. Collier's fortunate specimens show by the fruit that it is undoubtedly a Dicksonia, and further that the two forms of foliage occur on the same frond. The other Dicksonia, although a mere fragment, is with little doubt the same as D. Borejensis described late in 1904 from Amur. What I here called Podozamitcs lanccolatus latifolius was determined by Professor Fontaine as $P$. distantinervis, a well-known Potomac species. However, I have compared the types of this Potomac species with the specimens in hand, and can confidently say that they are not the same, and moreover that they are not separable from $P$. lanccolatus latifolius. There are also several other species identified by Professor Fontaine with Potomac species that I have carefully studied and compared, and can only conclude that he was in error, but as they are not present in Mr. Collier's collection, it is not necessary to mention them otherwise than to point out that it was undoubtedly upon these and those above enumerated that he based his conclusiou as to the relationship between the Potomac of Virginia and the Corwin of Alaska. This relationship does not seem to me to exist in fact. The Ginkgo present in these collections is a large-leaved form that Fontaine has separated from $G$. Huttoni as a new variety, but $I$ can at the moment see but little warrant for separating them from the widely spread $G$. digitata.

Again I state that at present $I$ can see no valid reason for regarding this flora as other than Jurassic. or in any event as other than identical with the flora from castern Siberia, the Jurassic age of which is, so far as I know, universally accepted.

Although there is no indication in Mr. Collier's notes that more than one horizon is represented, nor is the thickness of the beds mentioned, I have tried to see if $I$ could detect any difference in 
position. In this I have not signally succeeded. None of the localities are represented by more than five species, and most of them yield but two or three, so the basis for comparison is slight. However, I should think that localities $4 \mathrm{~A}$ W 5 and $4 \mathrm{~A}$ W 9 , and possibly $4 \mathrm{~A}$ W 25 , are probably at the base of the section.

In the light of the new evidence, and the more refined discrimination of that already in hand, presented by Doctor Knowlton in the foregoing report, the assignment of the Corwin formation to the Jurassic system can not be questioned. The determinations made indicate little or no variation in the flora through the whole thickness of the formation, since the lots indicated by Doctor Knowlton as probably near the base of the section are, on the contrary, well distributed through it. It is reasonable to expect some changes in the flora from the base to the top of a formation of such great thickness, but in this case the variation, if it exists, will probably be detected only by the paleobotanist after a critical personal examination of the section. No coal-bearing rocks of Jurassic age comparable with the Corwin formation have been found elsewhere in Alaska, and in northern Alaska no other formation yet discovered can be definitely assigned to the Jurassic, though, as indicated, the formation is probably extensive in its distribution within the Arctic Slope province.

Along the Pacific seaboard of Alaska Mesozoic beds, including Triassic, Jurassic, and Jura-Cretaceous, are extensively developed. $a$ In this general region Jurassic rocks are reported from many localities distributed all the way from Dixon Entrance to the Alaska Peninsula and for 100 or more miles inland. These find their greatest development on the west shore of Cook Inlet and the south shore of the Alaska Peninsula, where Martin $b$ reports a section comprising about 8,000 feet of strata, composed of shales, sandstones, conglomerates, and interbedded volcanic materials, and containing middle and uppur Jurassic faunas. In the Central Plateau region of Alaska no rocks that can be definitely assigned to the Jurassic have yet been discovered.

\section{UPPER MESOZOIC BEDS.}

Southwest of the area occupied by the Corwin formation, and lying between it and the Carbouiferous rocks exposed at Cape Lisburne, there is a series of beds which though they resemble the Corwin rocks are easily differentiated from them on lithologic grounds. These rocks outcrop along the coast from a point 2 miles west of Corwin Bluff to within 3 miles of Cape Lisburne and extend inland in a southeasterly direction, as shown in the geologic map, Pl. I. The exact contact of this formation with the Corwin was not exposed, or if observed its significance was not understood, though the field relations of the two formations are definitely known at a number of localities. Continuous sedimentation and conformity between the formations are indicated, though the possibility of thrust faulting along the contact should not be overlooked. This formation is therefore provisionally regarded as overlying the Corwin and constituting an upper member of the Mesozoic series. At its contact with the Carboniferous rocks near Cape Lisburne the field relations shown in fig. 6 present unmistakable evidences of a thrust fault which brings the Carboniferous above it.

Lithologically this formation consists of sandstones and shales, with the former in the ascendant. The sandstone beds range in thickness from a few inches to 20 or more feet. They resemble the sandstones of the Corwin formation, but taken as a whole are probably somewhat less gritty and contain no conglomeratic material. The shales which are interbedded with the sandstones are dark colored and sometimes micaceous, so that they have a silvery sheen on the bedding faces. In a few instances ripple marking was observed on shaly beds.

a Brooks, A. H., The geography and geology of Alaska: Prof. Paper U. S. Geol. Survey No. 45, 1906, pp. 225-237.

b Martin, G. C.; Petroleum fields of the Pacific coast of Alaska: Bull. U. S. Geol. Survey No. 250, 1905, pp. $37-45,61-53$. 
No definite fossils were found, after a diligent search, either in the sandstones or the shales, though indistinct impressions of vegetable fragments, probably detrital material, were found in some of the beds. The structure of the formation, while it consists of simple open folds near its boundary with the Corwin, becomes increasingly complicated as the fault at the contact with the Carboniferous rocks is approached. Overturned folds and minor thrust faults with axes extending in a general way northwest and southeast are typical features. The photograph, PI. IV, $B$, shows folded beds and a fault with a displacement of about 20 feet, which were observed one-fourth mile from the contact with the Carboniferous.

Fig. 6, which is a ground plan of the outerops adjoining the contact between the Mesozoic and Carboniferous, will clearly present the evidence from which the existence of a profound fault at this place is inferred. The Carboniferous rocks here consist of soft black slates and shales, with occasional beds of cherty limestone, all of which are intensely crumpled and eroded to base-level. The outcrops of several of the cherty beds were traversed and carefully mapped, and were found to end abruptly at the line of contact with the Mesozoic. The overthrusting of the Carboniferous is inferred from the observed dips in both formations and from the prevailing dips of the minor thrust faults observed in the Mesozoic formation.

Owing to the complex structure of this formation, it was impossilile to definitely measure its thickness, but from the imperfect evidence obtained it is believed to be not less than 5,000 nor more than 15,000 feet, and for the purposes of this report it is estimated at 10,000 feet. Since no direct paleontologic or paleobotanic evidence was obfained, the age of the formation can only be inferred from its relation to the Jurassic Corwin formation which it overlies. It is therefore provisionally assigned to the Lower Cretaceous. On Anaktuvuk River, 400 miles east of Cape Lisburne, Schrader found a formation somewhat similar to this, both in its lithology and in its topographic relations to the Lisburne formation, which he called the Anaktuvuk series, $a$ and which contains Lower Cretaceous fossils. If the above assignment is correct, the upper Mesozoic formation of the Cape Lisburne region should be correlated with the Anaktuvuk series.

Lower Cretaceous rocks, usually determined as such by the presence of a single species Aucella crassicollis Keyserling, are widely distributed in Alaska. $b$

On the upper Koyukuk the Lower Cretaceous Koyukuk ${ }^{c}$ series consist of pink and reddish impure limestone, dark shale, slate, and some sandstone or arkose with occasional associated igneous rocks. On the Yukon the horizon is represented by a series of closely folded black slates, with some limestones and calcareous sandstones, which outcrop along the river for nearly 80 miles above the mouth of Charlie River. $d$

In the part of Alaska south of the Yukon Lower Cretaceous rocks are probably widely distributed, but in most cases it has not yet been possible to differentiate them from the Jurassic. No coal beds are known to occur in the Lower Cretaceous of Alaska, though the coals of Queen Charlotte Island are assigned to this series. $e$

\section{QUATERNARY DEPOSITS.}

The Upper Cretaceous and Tertiary iormations, reported by Schrader $f$ on Anaktuvuk and Colville rivers, 350 miles to the east but in the same general topographic

a Schrader, F. C., Reconnaissance in northern Alaska: Prof. Paper U. S. Geol. Survey No. 20, 1904, pp. 74-76.

b Brooks, A. H., The coal resources of Alaska: Twenty-second Ann. Rept. U. S. Geol. Survey, pt. 3 , 1901, pp. 527-528. The geography and geology of Alaska: Prof. Paper U. S. Geol. Survey No. 45, pp. $234-237$.

cSchrader, F. C., op. cit., p. 77.

$\alpha$ Collier, A. J., Coal resources of the Yukon: Bull. U. S. Geol. Survey No. 218, 1903, pp.16,17.

$e$ Brooks, A. H., Coal resources of Alaska: Twenty-second Ann. Rept. U. S. Geol. Survey, pt. 3, 1902, pp. 526-528.

$f$ Schrader, F, C., op. cit., pp. 79-83. 
province, are not represented in the Cape Lisburne region, where Pleistocene and Recent deposits rest unconformably on the older rocks, occurring in limited areas, usually in the forelands between the hills and the sea, but also in a few instances extending into the river valleys. On the geologic map, Pl. I, these horizons are not differentiated from each other, not only on account of the small scale of the map, but also because the time available for their examination in the field was limited. They offer material for much interesting speculation regarding the recent geologic history of the Arctic coast.

PLEISTOCENE DEPOSITS.

The Pleistocene deposits are differentiated from the Recent by the fact that they are sufficiently elevated above the sea or the present drainage levels to form low cliffs by the undercutting of surf or river. In the Cape Lisburne region such deposits present a variety of facies. West of Thetis Creek for about 2 miles a Pleistocene deposit, consisting of about 20 feet of well-stratified gravel and sand overlain by about 1 foot of soil and muck, rests on the edges of the Corwin formation. East of the mouth of Thetis Creek for about 3 miles a deposit, consisting of silt and ground ice overlain by from 6 to 10 feet of peat and tundra vegetation, rests on the edges of the Corwin formation, which is exposed on the beach in only a few places. The ground ice does not form a continuous layer, but occurs in irregular, more or less lenticular masses, varying in composition from pure ice to frozen silt. The formation extends back of the beach for one-fourth to one-half mile in a tundra plain cut by numerous deep channels and sink holes. The process of erosion in this plain is apparently as follows: The waters from the tundra surface falling over the cliff face expose the ground ice, which melts away rapidly until the edges of the peat layer sag down and cover it. In this way a gully is started at the edge of the cliff, which works back rapidly, since the water falling into the upper end is continually exposing the ice. The sink holes occur at the heads of these gullies, where the melting of the ice has been slightly in advance of the caving in of the tundra. Gullies and sink holes formed in this way are characterized by the bending and sagging of the surface layer over the edges of the beds which have been eroded. Wherever thawing is in progress the thick layer of peat emits a fetid odor, probably similar to that described by Dall $a$ at Elephant Point.

At many localities between Cape Sabine and Cape Beaufort ground ice of varying degrees of purity is overlain by gray silts and turf or talus from the hills. Where these deposits are undercut by the surf or exposed by other exosion the ice melts, undermining the formation of the bluff in broad cirque-like indentations usually less than 100 feet deep. The combined silt and water from such amphitheaters flows across the beach sands in walls of slimy mud, which are almost impassable. Vegetation over the unthawed portions of such deposits is very scanty, but along the overhanging edges of partly undermined cliffs and on the talus found below them grasses and other plants grow in comparative profusion. For about 3 miles west of Cape Beaufort there is gravel and sand free from ground ice and similar to the deposit west of Thetis Creek, which forms a bluff about 100 feet high. At one point sandstone of the Corwin formation outcrops at the base of this bluff.

On Pitmegea River a ground-ice formation, which was not examined by the writer, is described by Stockton ${ }^{b}$ as follows:

Ice cliff on the Pitmegea. - This ice cliff is about 25 miles from the mouth of the Pitmegea, at a place where the hills run their spurs out to the banks of the river, closing the picturesque valley that stretches away to the seacoast in an almost unbroken width of a mile. A glacier faces southward and receives the full benefit of the sunlight during the short polar summer. Gales have deposited particles of soil and debris of plants, along with their seeds, upon the surface of the ice to a depth of

a Dall, W. H., and Harris, G. D., Correlation pàpers-Neocene: Bull. U. S. Geol. Survey No. 81, 1892,

p. ${ }^{\text {Stockton, Charles H., Aretic cruise of the U. S. revenue cutter Thetis in 1889: Nat. Geog. Mag., }}$ vol. 2 , 1890, pp. 178-179. 


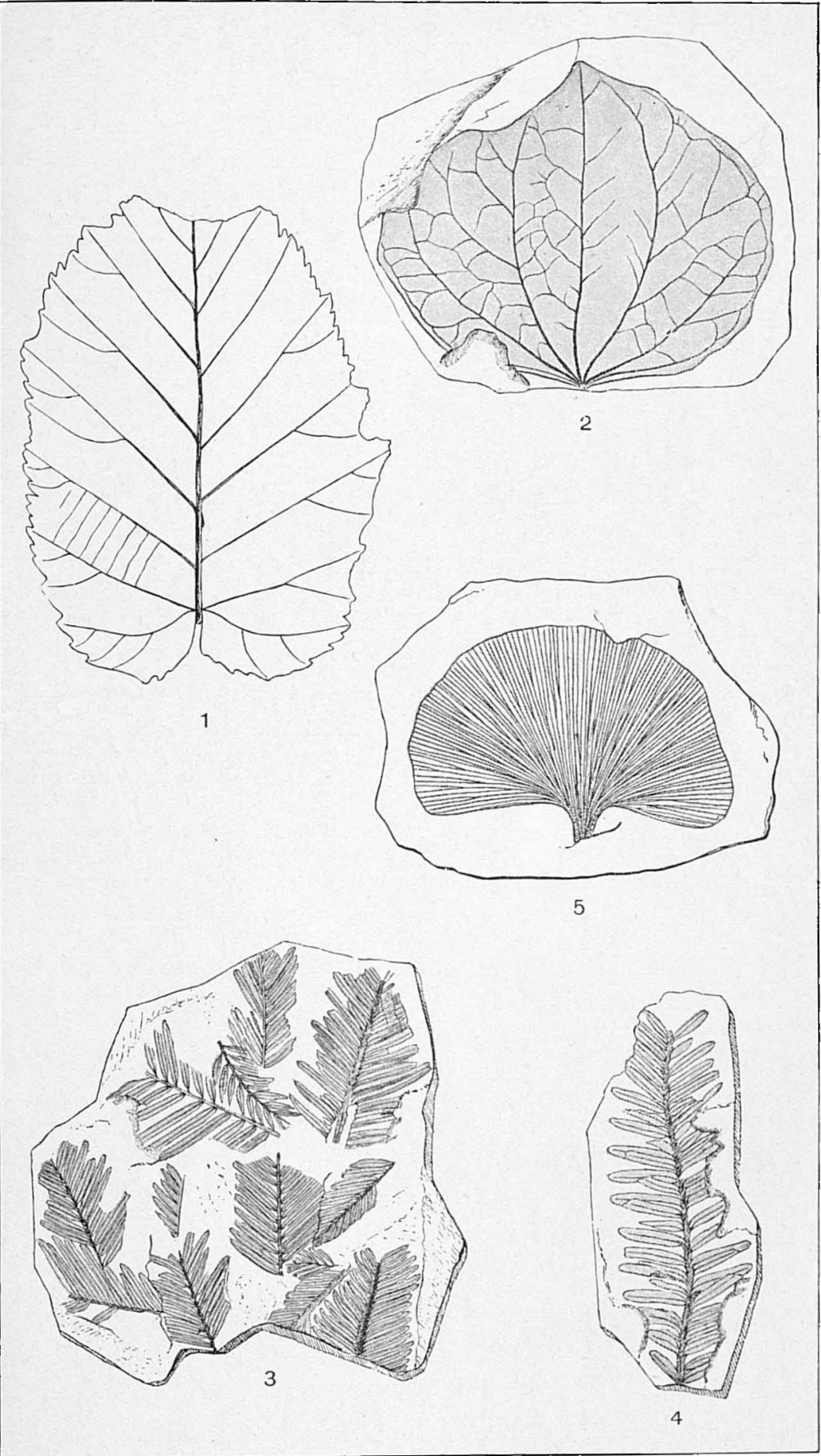

TERTIARY PLANTS FROM THE KENAI (EOCENE) FORMATION OF ALASKA.

1, Corylus McQuarrii. 2, Populus arctica. 3, Taxocium distichum miocenum. 4, Sequoia Langsdorfil. 5, Ginkgo adizntoides.

From Heer's "Flora Fossilis Arctica." 

from 4 inches to 1 foot. The snowfall of winter soon vanishes before the June sun, but the light covering above the glacier preserves it intact. Vegetation is warmed into life in a remarkably short time, and the brown coat left by the receding snow is almost miraculously transformed to a robe of green, studded here and there with bright polar flowers, buttercups, dandelions, yellow poppies, bright astragals, gentians, daffodils, and marguerites. The last are small and unobtrusive, showing in a modest way as if they wished to apologize to their sister flowers for their appearance among them. As toward beautiful orphan girls one can not resist a compassionate tenderness of feeling toward them. But these innocent little flowers, chaste as the ice field upon which they grow, bloom in the polar garden with as much right as the glacier's gentian. Besides flowers, there are the hardy grasses whose roots penetrate the light covering of soil to the ice bed, whence they derive their nourishment. A few Arctic willows are to be seen, but they only grow about a foot in length and trail upon the ground. Pitmegea River is gradually cutting into the glacier, receding from its opposite bank and leaving a bed of gravel behind. During the summer the ice melts away, leaving the soil protruding above it like the eaves of a house; when it protrudes too far for the strength of the grass roots it topples over into the river. At the freezing in September icicles form from the overhanging sod to the river ice below, forming a narrow portico 4 miles in extent.

None of these deposits, either of ice or gravel, are traceable to typical glaciers nor to any particular part of the Glacial epoch. They belong to the group of beds called Kowak clays and ground ice by Dall and others, $a$ which are widely distributed over the nonglaciated parts of Alaska and Siberia.

No fossil remains were found in place in any of these deposits, but fragments of the tusks and teeth of the mammoth, Elephas primigenius, were observed at two places in gravels directly derived from their localities. Their assignment to the Pleistocene series is therefore unquestionable.

\section{RECENT DEPOSITS.}

The deposits which have not been elevated above sea level, and are still in process of construction, are of two kinds-alluvial plains and marine beaches. The only considerable area of the former type is found in the delta of Kukpuk River, while the beaches form a fringe of varying width along nearly the whole coast. The largest area, about 80 square miles in the Point Hope peninsula, is in part a delta and in part a beach deposit.

The Kukpuk delta which forms the interior portion of this area is a plain from 10 to 15 feet above sea level. In its upper part, which alone is exposed, the deposit consists of stratified silts and sands overlain by peat and tundra vegetation, and its surface is broken by numerous lakelets and abandoned channels. It is reported that a large part of the area is underlain by ground ice, but of this the writer has no knowledge from his own observation. Along Kukpuk River the bed rock is exposed below the silts in several places, and it is not probable that the depth of the formar tion at any point exceeds a few fathoms. The sediments brought down by the river each year contribute to the extent of this formation at the expense of Marryat Inlet. The lands along the coastal margin of the Point Hope peninsula, which separate Marryat Inlet from the sea, are deposits of the latter type, and consist of two sand and gravel spits which extend seaward from the north and south sides of this delta and converge and meet about 15 miles from the mainland. They vary in width from a few hundred feet to a mile, rise from 10 to 15 feet above sea level, and, except in time of unusually severe storms, are entirely beyond the reach of the waves. A native graveyard located near Tigara has not been disturbed by sea waves for several generations, but during severe storms waves break over some of the narrower portions and the water of the inlet is never fresh. In addition to these two main spits there

a Dall, W. H., and Harris, G. D., Correlation papers-Neocene: Bull. U. S. Geol. Survey No. 84,

1892. (Map opposite page 268.) pp. $91-93$.

A comprehensive review of the literature regarding this interesting formation both in Alaska and siberia has recently been prepared by A. G. Maddren under the title "Smithsonian Exploration in Alaska in 1904 in search of mammoth and other fossil remains:" Smithsonian Misc. Coll., vol. 49, No. 1584, 1905.

Bull. $278-06-3$ 
are several gravel bars in Marryat Inlet which curve northward from its southern shore and are exposed only at low tide. These have not been definitely located on the map, but are mentioned, since they probably indicate previous stages in the development of the point.

The surface materials vary from moderately coarse sand to well-rounded gravels with some pebbles 3 inches or more in diameter. As far as observed, all this material is traceable to the Paleozoic formations of the neighboring mainland and a large part of it may have been contributed by Kukpuk River. These spits are probably in the main the product of the waves and prevailing currents. The material for the south spit was derived from the cliffs at Cape Thompson and the delta of Kukpuk River. It was worked northward by the prevailing current which swings off from the shore at this point, partly on account of the angle in the coast line and partly on account of the growing delta of the Kukpuk. The counter current or eddy on the north side of the Kukpuk delta was at the same time bringing material for the north spit from the cliffs south of Cape Lisburne. This spit was of slower growth than the south spit which curved northward from its extremity, forming the bars noted in Marryat Inlet. As the north spit extended beyond these bars the south spit extended in its present direction. The two come together about 15 miles from the mainland and $1 \frac{1}{2}$ miles from the point. It is reported that the point is still growing seaward, but of this the writer has no definite evidence.

In the region explored east of Cape Lisburne there are several barrier beaches shutting in narrow lagoons behind them, none of which are of considerable extent. The largest, which lie between Cape Lisburne and Corwin Bluff, are not over 2 miles in length and one-fourth mile in width. About 10 miles north of Cape Beaufort a lagoor of the same type but of greater width begins and extends along the coast continuously for over 100 miles. As was stated in connection with the sand spits at Point Hope, such barrier beaches are usually attributed to the action of waves and currents. In the Arctic Ocean, however, the action of the grounded ice pack on such beaches must be taken into consideration. As has been already noted (pp. 10-11) the ice pack occupies about half the depth of the Arctic Ocean and will ground at from 3 to 6 fathoms, or in most cases from 1 to 2 miles offshore. If, then, the ice pack is driven ashore by the wind so that the ice banks up along the beach, as sometimes happens, a great deal of material from the sea floor may be scraped up and added to the beaches. At Blossom Shoals, several miles off Icy Cape, about 100 miles northeast of Cape Lisburne, the soundings show a succession of ridges parallel with the coast. These have gentle slopes on their seaward side and steep slopes landward, and shift their positions from year to year. They are attributed to the action of the grounded ice pack, and if the facts are as represented this conclusion is warranted.

The writer was informed by Joseph Tuckfield, who resides near the entrance to Marryat Inlet at Point Hope, that his residence has been more than once threatened by the driving ashore of the ice pack; and Dr. E. O. Campbell, Government school teacher at Cape Chibukak, St. Lawrence Island, whose residence is nearly one-half mile back of the beach, reports that he has often feared the destruction of the mission buildings from the same cause. The beach at Cape Chibukak is marked by a series of regular ridges parallel to the shore, said by Doctor Campbell to have been pushed up by the ice pack. In view of these considerations the barrier beaches of the shores of the Arctic Ocean and Bering Sea, though in nearly all respects they resemble the barrier beaches formed by wave and current action in southern latitudes, must in the opinion of the writer be regarded as in part due to material pushed up from the sea floor by the ice pack and only transported in a minor degree by wave action. Barrier beaches of this type are of common: occurrence along the shores of the Arctic Ocean in Alaska from Cape Prince of Wales to McKenzie River. 


\section{ECONOMIC GEOLOGY.}

\section{INTRODUCTION.}

The only mineral resources of the region which are believed to be of economic importance are the coal deposits. As has been shown the rocks are all of sedimentary origin and comparatively unmetamorphosed. It is, therefore, not considered probable that any important deposits of either gold or silver occur in them, though gold-bearing veins have been reported from the head of Pitmegea River. $a$

Coals have been found in Alaska and adjacent parts of British Columbia in not less than five geologic horizons. These are Carboniferous, Jurassic, Cretaceous, Tertiary, and Quaternary, representing the three geologic eras, Paleozoic, Mesozoic, and Cenozoic.

Of these only the Carboniferous, Jurassic, Cretaceous, and Tertiary have been found of economic value. As a general rule, other things being equal, the older coals are of better quality than the younger.

The age of the coals is indicated by the character of the plant remains and other fossils found in the underlying and overlying bed rock. Since it is of value to prospectors to be able to distinguish within very broad limits as to which of these major divisions the coal which he may have discovered belongs, a few remarks as to some of the principal types which characterize these various divisions will he here incorporated. The land plants from which the Paleozoic coals were formed were mostly ferns and relatives of the club-moss family (Lycopodiacere). Some of these ancient representatives of the lycopods, or "ground pines" as they are often called, were of great size, resembling in some respect the evergreens of the present day. Two of the most common and characteristic of these. were Lepidodendron and Sigillaria. The small leafy twigs of the former often suggest branchlets of the cypress or yew, but the fragments of larger stems $(\mathrm{Pl} . \mathrm{V}, A)$, which are more common, have their bark marked by more or less elongated diamond-shaped meshes or "bolsters," in the interior of each of which is situated a small, usually rhomboidal, leaf scar. The large stems of Sigillaria, on the other hand, are characterized either by rather broad flat ribs, each rib bearing a Jongitudinal row of scars, or by a more or less distinct series of relatively large hexagonal meshes or cushions containing the leaf scars. In general, the presence of fossils of these types is most often made known by the occurrence of fragments of their characteristic roots, Stigmaria (Pl. V, B), which can be easily recognized even by amateurs by the circular depressions, each of which contains a small round prominence surrounded by a smooth circular border. These pits correspond to the points of attachment of long, ribbon-like or fistulose radiating rootlets, which resemble slender leaves but have become distorted in most instances.

The shales associated with the coals belonging to the same group as the older (Paleozoic) coals of the Cape Lisburne region usually contain fragments of a delicate and finely dissected fern (Sphenopteris), similar to that shown in Pl. V, C. Though the size and shape of the pieces of frond may vary greatly, the slender lobes of the delicate, sometimes lax, pinnæe are not difficult to recognize. Specimen fragments of the fern, or of Lepidodendron and Sigillaria, are most apt to be found in the shales or slates just above coal seams; but the Stigmaria roots are more common in the underclays of the Carboniferous coals.

The Mesozoic era is also characterized by ferns and palm-like plants with parallelveined leaves, but Lepidodendron and Stigmaria are always wanting. The Jurassic and Lower Cretaceous horizons of Alaska can be recognized by the presence of plants called "cycads," leafy branches of which are shown in Pl. V, $E$ and $F$. The cycads, which perhaps are most closely related to the conifers, have usually short,

a Stockton, Charles H., Arctic cruise of the U. S. revenue cutter Thetis in 1889: Nat. Geog. Mag., vol. 2, p. 171 . 
thick trunks with a circle or crown of large pinnate leaves at the top, the lower portions of the trunk being covered with usually large, rudely diamond-shaped scars, which represent the places whence earlier leaves have fallen. The leaves look much like those of certain palms, having a thick midrib or axis, along the sides of which are arranged the narrow parallel-veined leaflets. There are never any dicotyledons associated with the cycads in these beds, though there are often ferns and horsetails (Equiseta).

The Upper Cretaceous horizons contain cycads associated with plants of more modern aspect called "dicotyledons"-that is, plants having netted-veined leaves, such as the oak, sassafras, sycamore, poplar, etc. These are also plants with palmate leaves such as those of Ginkgo, shown in Pl. V, D.

The fossil plants of the Cenozoic era, including the Eocene, Miocene, and Quaternary borizons, include few if any plants with parallel-veined leaves, except occasional grass or sedge-like types. The era is characterized by dicotyledonous plants, such as oaks, poplars, and the host of other deciduous trees, shrubs, and herbs, as well as by conifers of the Redwood type. Plate VI shows some of the characteristic plants from the Eocene (Kenai) series, the most extensive Cenozoic coal-bearing formation in Alaska.

In the Cape Lisburne region coals of two distinct types occur in rocks of Paleozoic and Mesozoic ages. The Paleozoic coals are bituminous and of a very high grade, but are of limited extent. The Mesozoic coals are also bituminons, but of low grade. They are distributed over a large field, and on account of the thickness and extent of the beds are of greater economic importance than the older coals.

THE MESOZOIC, COAL FIELD.

EXTENT.

The Mesozoic coals occur in the Corwin formation, which is known to be of Jurassic age. Its extent within the region investigated is shown by the geologic map (Pl. I).

The southern boundary of the formation runs in a southeasterly direction from the coast for about 10 miles, beyond which it turns south. The same coal has been found in the interior 20 miles south of Cape Beaufort, and similar coals have been reported to occur on the headwaters of Colville and Chipp rivers, 300 miles east of Cape Lisburne. Its continuity through this distance has not been deternined, though it may be inferred from topographic evidence. It is safe to say that the coal-bearing area is not less than 300 square miles, while it may be found to be much greater.

The topography of this field consists of low rounded hills and ridges usually less than 600 feet in elevation, which trend parallel with the strike of the bed rock and are formed by the outcrops of harder beds. The portion of this field which lies between Corwin Bluff and Cape Sabine (see map, Pl. VII) contains the only mines in the region which have been worked, and has been examined in somewhat more detail than the remainder.

The distribution of the coal beds as well as the relation of bed-rock structure to topography is shown in the map (Pl. VII), which is based on field notes made by the writer. From this map it will be seen that a well-defined ridge extends southeastward from Corwin Bluff. This ridge is formed by the outcropping of a persistent conglomerate bed which, as already stated, gives a definite key to the stratigraphic relations. The continuance of the coal beds away from the coast line is inferred from the continuance of this conglomerate, and croppings of coal back from the coast have been observed at only the few points which are indicated. The vertical distribution and approximate number of the coal beds is shown in the columnar section (Pl. IX). Many of these beds are known only from obscure croppings and only a few of them have been sufficiently developed to permit accurate measurement or sampling. 
THE COAL BEDS.

The beds which have been found to be of economic importance fall readily into two groups, the Corwin and Thetis, though further development may show that the intervening strata also contain some workable coals. Those which seem to be of value are described in order from the top of the formation downward, while in the portions of the field not covered in the nap (Pl. VII) the croppings of coal which have been observed are described without reference to stratigraphic position.

\section{CORWIN GROUP.}

The coal beds of the Corwin group outcrop in the sea cliffs east and west of Corwin Bluff, which is a cliff 200 feet high about 28 miles east of Cape Lisburne. The bluff itself rises sheer from the water, but about half a mile west of it there are narrow rocky beaches along the foot of the cliff, and a few hundred yards east there is a short sand beach at the mouth of a small creek. The bedding strikes $\mathrm{N} .75^{\circ} \mathrm{W}$. and dips about $40^{\circ}$ southeast.

The highest coal seam noted in the series outcrops in the sea cliff $1 \frac{9}{8}$ miles west of Corwin Bluff. It is exposed by a recent rock slide from the cliff and contains $4 \frac{1}{2}$ feet of coal without partings. The roof and floor are soft shales or shaly sandstones.

A sample of this coal taken by Washburne, numbered $4 \mathrm{~A} \mathrm{~W} 7$, was assayed by W. T. Schaller with the following result:

Analysis of coal from sea cliff $1 \frac{3}{8}$ miles west of Comwin Bluff, Alaska.

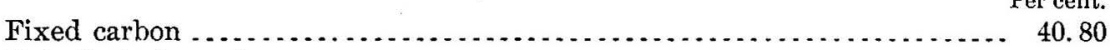

Volatile hydrocarbon . . . . . . . . . . . . . . . . . . . . . . . . . . . . . . . 41.30

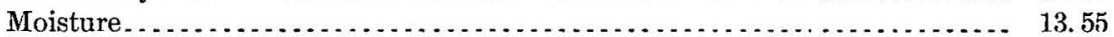

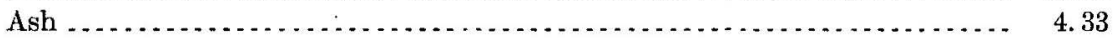

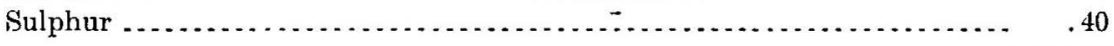

$\overline{100.38}$

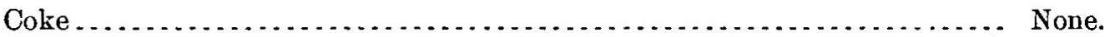

Color of ash . . . . . . .

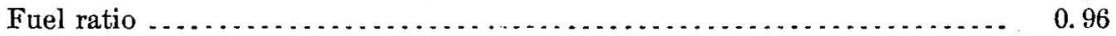

A second seam which has yielded some coal is about 1,000 feet lower stratigraphically, the intervening beds being shales which contain several coal seams either too small or too impure to be of value. This bed outcrops in the sea cliff three-fourths of a mile west of Corwin Bluff and is developed by a tunnel about 40 feet long driven without timbers. The photograph (PI. VIII), which is probably of this bed, is taken from Schrader's report and shows the nature of the development work done in 1901.

The seam is 5 feet thick and has two thin clay partings, one 1 foot from the floor, the other about the middle. The roof is shaly sandstone which stands well without timbers. The floor is hard clay or clay shale and contains a smaller seam several feet below the one that has been developed.

A sample of this coal taken by the writer across the bed as exposed in the face of the tumnel, excluding the two partings, was assayed by W. T. Schaller with the following result:

Analysis of coal from sea cliff three-fourths mile west of Corwin Bluff, Alaska. Per cent

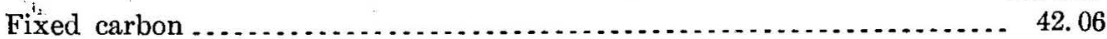

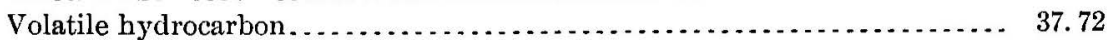

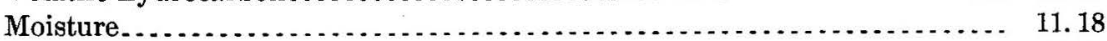

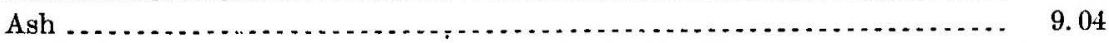


Per cent.

Coke None.

Color of ash Light gray.

Fuel ratio.

1.11

The coal in the face of the tunnel is solid, and though frozen does not break up greatly on exposure to the air. A sample exposed to the air for several months in the office is still solid except for some cracks, which may be dne to other causes than evaporation, but a sample which had been thoroughly air-dried in the office for several months slacked to fine grains when again put in water. When finely powdered the coal loses moisture rapidly, so that an assay made from a portion of a sample which had been ground in an agate mortar showed ouly 4.66 per cent moisture as compared with the 11.18 per cent obtained from coarsely-ground material. The specific gravity of a sample of the air-dried coal was roughly determined to be 1.39.

The next bed of importance is about 500 feet lower stratigraphically, the intervening beds being shales which contain 4 or 5 small, unimportant, coal seams. This is probably the original Corwin vein and has yielded a considerable amount of coal. It has been developed by a tunnel from the cliff face and an air shaft from the level surface above the cliff which is about 75 feet above the sea. In the summer of 1904 the entrance to the tunnel was closed by a great mass of ice, the remnant of snowdrifts formed the winter before, and the air shaft was filled with water, so that the workings were inaccessible and the coal bed could not be measured. It is reported to have a total thickness of 16 feet, of which 7 feet is clear coal-with no partings, while the remainder contains.several partings and is without value.

Two samples were taken by the writer from sacks of coal mined the year before, which were found frozen in the ice at the foot of the cliff. One of these (No. $4 \mathrm{~A}$ $\mathrm{C} 4$ ) is a fair sample of the material found in the coal sacks, and represents the coal as it has actually been mined and shipped. The other sample was taken from the same sacks but was washed before sampling. It probably represents approximately the quality of coal that could be obtained from this bed by careful mining. The analyses by W. T. Schaller are as follows:

Analysis of coal from sea cliff west of Corwin Bluff, Alaska.

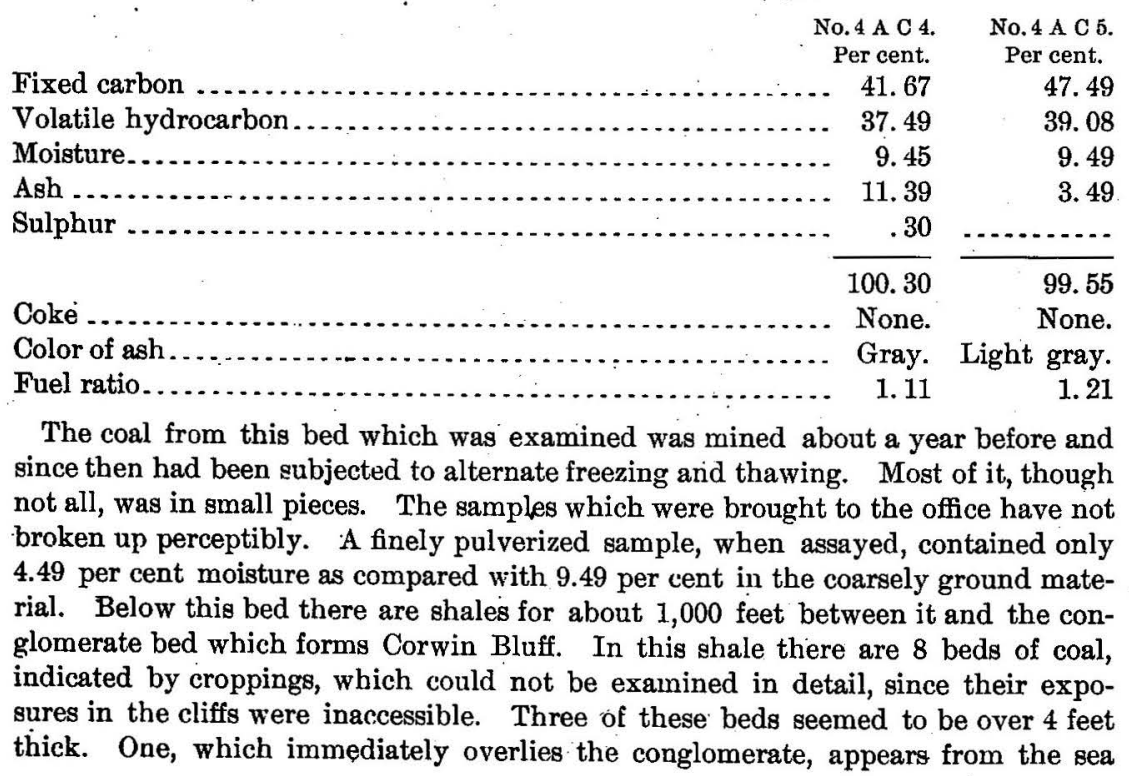




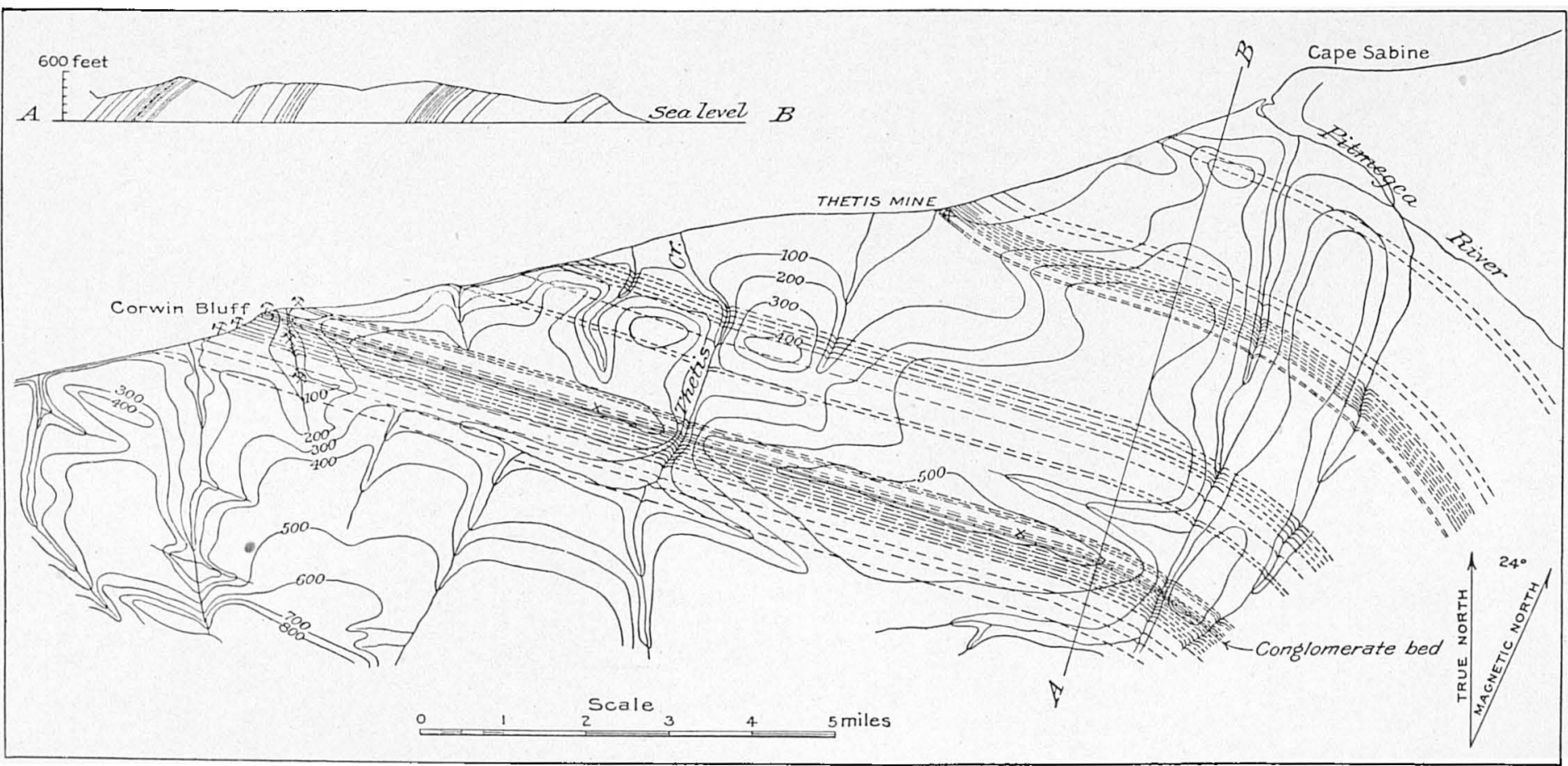

MAP OF PART OF CORWIN COAL FIELD.

Showing position of coal croppings and reiation of topography to bed-rock structure. 

to be about 30 feet thick and of impure coal. Another about 12 feet thick and a third 4 feet thick are reported to be clean coal of good quality. The conglomerate bed at Corwin Bluff is from 10 to 20 feet thick.

Immediately below the conglomerate, and lying between it and a massive sandstone, there is an irregular coal bed from which, it is reported, 500 tons of coal were taken in one season. This bed bas been affected by shearing movements of the adjacent strata, and the coal is brecciated and polished, though it can be obtained in large pieces. In other parts of the series the adjacent shales are soft beds which have yielded equally to shearing strains, so that the coal beds have remained comparatively unaltered. But in this case, the conglomerate and sandstone beds being rigid, the whole effect of such forces has been felt by the coal bed which lies between them. In the face of the bluff the coal appears in a series of isolated masses, as shown in the sketch (fig 8 ), which is parallel with the strike of the bedding.

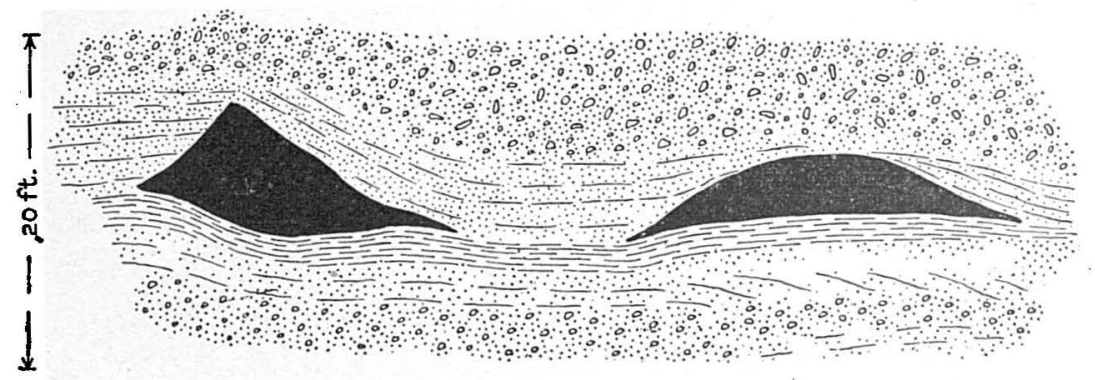

FIG 8.-Section of irregular coal bed underlying the conglomerate at Corwin Bluff.

Since this bed was partially mined out the face of the bluff has fallen down, making the coal inaccessible, and the samples for analysis were taken from large pieces which had fallen down, and may not be fully representative. The result of the analysis by Schaller is as follows:

Analysis of coal from Comvin Bluff, Alaska.

Per cent.

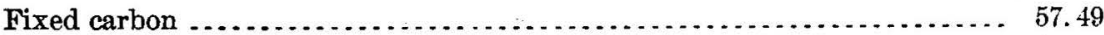

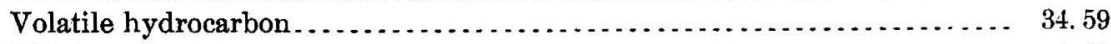

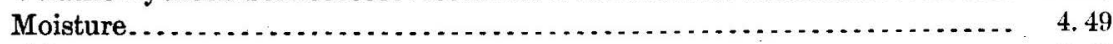

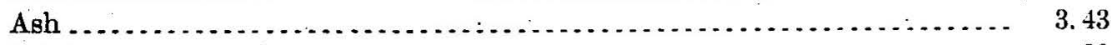

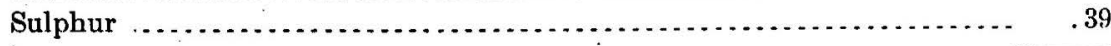

100.39

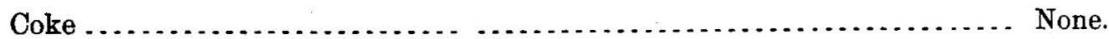

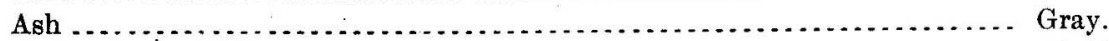

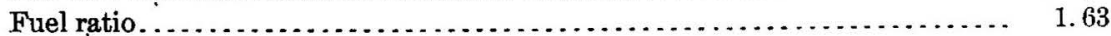

Specimens of this coal which were found on the talus at the foot of the cliff and had probably been long exposed to the weather seemed to be entirely unaffecterl. The specific gravity of a sample which had been exposed to the air for several months was roughly determined to be 1.30 . While the analysis indicates that this is the best coal sampled from the Corwin formation, the irregular nature of the bed makes it doubtful if it can ever be profitably worked.

The next bed of importance in the series outcrops in the sea cliff about 1,000 feet east of Corwin Bluff, and is stratigraphically 400 feet below the conglomerate bed, the intervening strata being sandstones and shales containing.many plant remains, and one small coal bed below the irregular one noted above. The section of the coal bed from the top down is as follows: Clean coal, 1 foot; black shale, 1 foot; clean coal, 4 feet. The coal from the upper and lower benches is about alike. 
The roof of this bed is black shale $1 \frac{1}{2}$ feet thick, above which is shaly sandstone. The floor of the bed is black shale 2 feet thick, below which there is 1 foot of impure limestone.

This bed has been partially opened at the top of the cliff, which is about 100 feet high, and has yielded for whaling ships some coal said to be of good quality. The face of the cliff up to 75 feet above the sea was covered in July and August, 1904, with snow and ice, the remnant of snowdrifts accumulated the winter before.

A sample across the bed was taken by the writer, excluding the shale parting noted above. The result of its analysis by Schaller is as follows:

Analysis of coal from sea cliff east of Corwin Bluff, Alaska.

Per cent.

Fixed carbon .............................................. 48.47

Volatile hydrocarbon . . . . . . . . . . . . . .

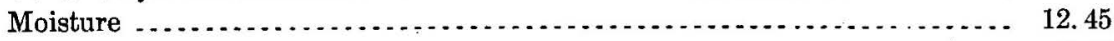

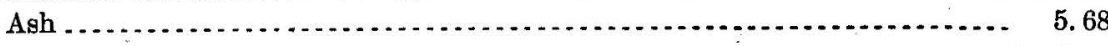

100. 00

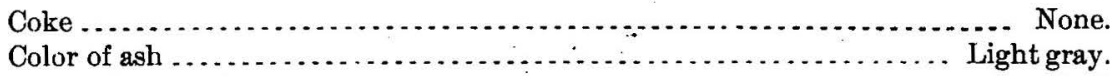

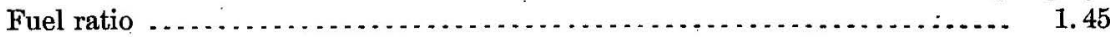

The sample was taken from the croppings of the bed, where it was considerably broken up by weathering.

About 50 feet below this bed there is an undeveloped bed which appears from the croppings to be about 2 feet thick. Below this for about 8,000 feet no coal beds above 1 foot in thickness were observed by the writer, though thin beds have been noted at several places, as will be. seen from the section, Pl. IX.

THETIS GROUP.

The coal beds of the Thetis group outcrop on the coast 6 miles east of Corwin Bluff, and are stratigraphically about 8,000 feet below the lowest bed of the Corwin group.

The outcrop along the coast is near a sandstone cliff about 30 feet high, the seaward end of a low ridge which extends inland in a southeast direction. It is about $4 \frac{1}{2}$ miles west of Cape Sabine and 2 miles east of the mouth of Thetis Creek. The coal here is reported to have been worked first by a whaleman who found all the beds accessible at Corwin Bluff already occupied by the crews of other ships, and was directed to this place by natives. The United States revenue cutter Thetis coaled here in 1888. It is reported that when the bed was discovered its outcrop extended across the beach, standing above the sand, and a large amount was easily obtained. In 1904 extensive snowdrifts covered the beaches and the cliff face so that no outcrop was seen. The bedding strikes N. $60^{\circ} \mathrm{W}$. and dips southwest at an angle of about $20^{\circ}$.

The vein which was worked in 1888 is probably one that overlies the massive sandstone which forms the cliff noted. Croppings on the level ground above the bluff indicate two coal beds of considerable thickness with 15 or 20 feet of shale between. Reports of the workings indicate that the vein has a thickness not less than 6 feet. In about 700 feet of dark shales underlying the sandstone bed ten coal beds were noted, only two of which are of possible economic value.

The first, of these is about 250 feet below the Thetis bed, and outcrops about 100 feet east of the high sandstone cliff. It contains 4 feet of clean coal without partings, and has for roof and floor black shales which contain several small coal seams. A sample across this bed, where it was exposed by the undercutting of the surf on the cliff, was taken by Mr. Washburne, and was assayed by W. T. Schaller with the following result: 


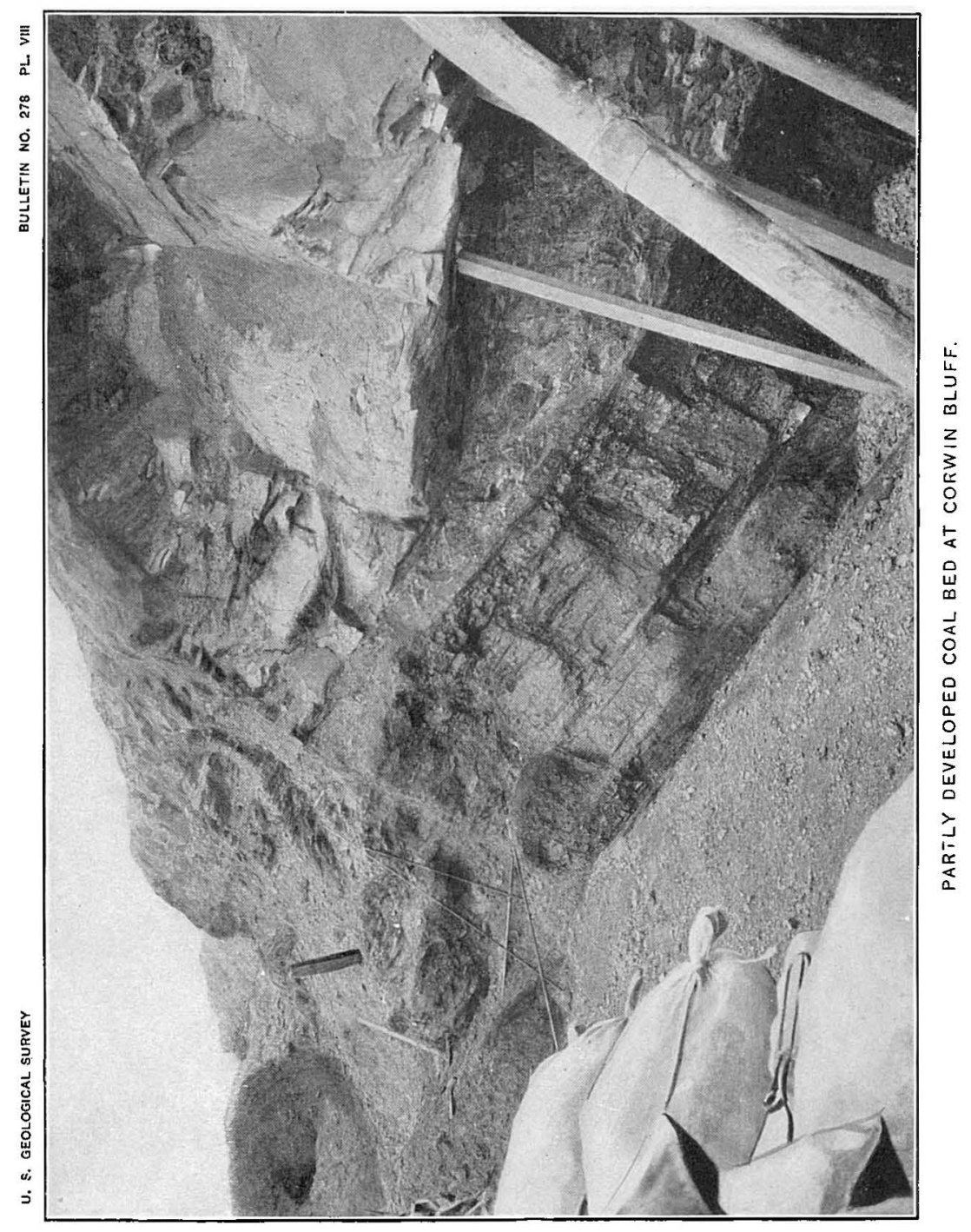





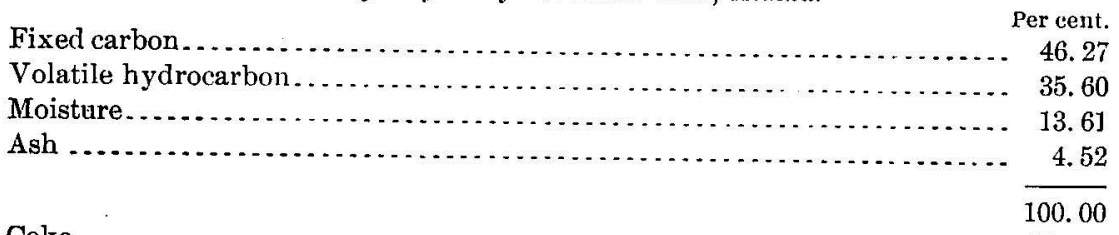

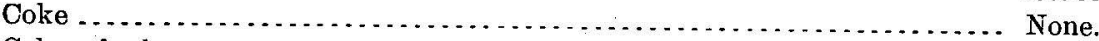

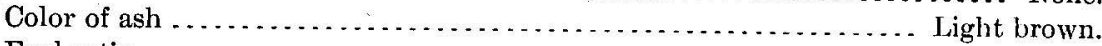

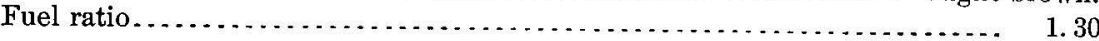

As is noted above, the sample was taken from a natural exposure which was frequently drenched by the waves, and the quality of the coal may have been slightly affected. The coal in the croppings is broken up into small pieces.

A second seam which appears to be of workable size is about 200 feet lower in the column and outcrops about 600 feet farther east. It contains 3 feet of clean coal without partings, below the same thickness of bony coal which is probably worthless. No analysis was made of the sample from this bed.

Below the beds of the Thetis group there are about 3,000 feet of shales and sandstones, ontcropping between Thetis mine and Cape Sabine, in which several coal beds have been noted, but none are of commercial value. East of Cape Sabine the structure changes, so that the outcrops of the beds described above are probably repeated, but the work has not been sufficiently detailed to identify them. The coal-bearing formation is not exposed in sea cliffs, and the croppings in the interior are not well defined.

\section{EAST OF CAPE SAIBINE.}

Croppings of half a dozen or more coal beds were seen south of a camp 10 miles east of Cape Sabine. One of these which was well exposed was found to be over 4 feet thick. The beds strike N. $80^{\circ}$ E. and dip north from $20^{\circ}$ to $40^{\circ}$.

\section{CAPE BEAUFORT.}

The occurrence of coal at Cape Beaufort, 40 niiles east of Corwin Bluff, was noted by Mr. Collie $a$ seventy-five years ago. At this point there is a hill 500 feet high, but the cliff is made up of Quaternary gravels, ground ice, and talus from the hill, so that there are no good natural exposures of the coal-bearing strata. In the hasty examination made by the writer the croppings of four coal beds were discovered on the hill, but no measurable exposures were found. Schrader, $b$ who visited the locality in 1901, reported that he saw a partially developed coal bed 6 feet thick, one-eighth mile from the coast. The beds strike S. $45^{\circ} \mathrm{E}$. and dip $20^{\circ} \mathrm{SW}$.

\section{WAINWRIGHT INLET}

The writer's examination of this coal field ended at Cape Beaufort, but its continuation to the north is inferred from coal found along the beach and dredged up from the sea floor.c

The most northerly occurrence yet reported of the coal along the coast is at Wainwright Inlet, latitude $70^{\circ} 37^{\prime}$, longitude $159^{\circ} 45^{\prime}$. Here it is said by Mr. Woolfe, $l$ who discovered it in 1889, to occur on the banks of Kuk River, which flows into the inlet.

aZoology of Captain Beechey's voyage, London, Henry G. Bohn, 1839, p. 173.

$b$ Schrader, F. C., Reconnaissance in northern Alaska: Prof. Paper U. S Geol. Survey No. 20, 1904, p. 110 .

cZoology of Captain Beechey's voyage, p. 174.

Dall, W. H., Coal ard lignite in Alaska: Seventeenth Ann. Rept. U. S. Geol. Survey, pt., p. 1820.

d Report on population and resources of Alaska: Eleventh Census, Washington, 1893, p. 133. 
Schrader collected $a$ fossil plants at Wainwright Inlet in 1901, which indicate that the Corwin formation is present there, and though he was unable to visit the locality mentioned by Woolfe he found samples of apparently good coal near the point where the fossils were collected. A sample collected by Schrader and analyzed by George Steiger was as follows:

\section{Analysis of coal collected near Wainwright Inlet, Alaska.}

Per cent.

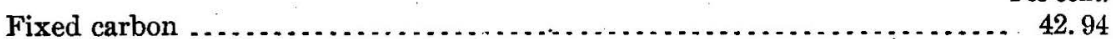

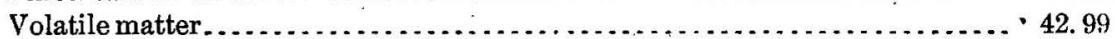

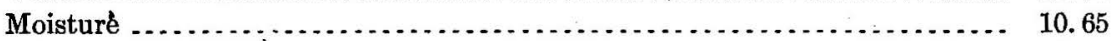

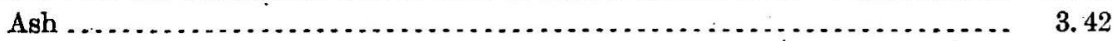

100. 00

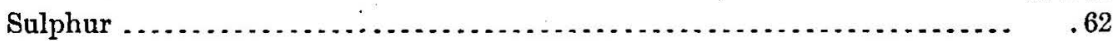

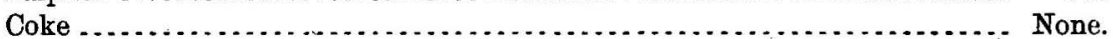

Fuel ratio . . . . . . . . . . . . 99

The analysis resembles that of the coal from the upper bed of the Corwin'formation at Corwin Bluff.

INLAND EXTENSION.

The present investigation was necessarily confined to a strip a few miles wide along the coast, but the inland extension of the coal field can be reasonably inferred from topographic evidence. Residents of the region who have made the trip from Point Hope to Cape Sabine by way of Kukpuk and Pitmegea rivers report that they found coal at their camp on the portage between these rivers. This camp could not have been less than 20 miles inland southeast of Cape Sabine. Coal has also been reported from the Colville, near its headwaters, by Ensign Howard $b$ of the United States Navy, who discovered it in 1886 , and by James $\mathrm{S}$. Reed, $c$ who visited that region in 1903. The topography of the upper Colville basin is reported to be undulating with low hills, the rocks consisting of a sandstone formation in which thick veins of bituminous coal outcrop along most of the creeks.

Howard makes the following statement in regard to the coal: "During the afternoon we passed a hill about 500 feet in elevation with outcrops of coal on the sides, and beyond the coal were found pieces of a substance called wood by the natives. It was hard, brittle, light brown in color, very light in weight, and burned readily, giving out quantities of gas. This material was scattered around in all shapes, sizes, and quantities." Dall $d$ suggests that this material may be ozocerite, but no samples of it were brought away. Some material answering to this description was found on the headwaters of Kivalina River last summer by W. Thompson. . It is a sort of brown "cannel" coal and burns readily, evolving much gas and flame. Some of the coal beds at Corwin Bluff are reported to contain cannel coal, though no samples were obtained.

Although the continuity of the Corwin coal-bearing formation to this point has not been demonstrated, it seems probable from the facts noted above that the coals of Colville River are of the same horizon as those on the coast.

The rocks of the Corwin formation were not recognized by Schrader along Anaktuvuk or lower Colville rivers, though a Lower Cretaceous formation called the Anaktuvuk series, which is not coal bearing, occurs on the river of that name. $e$

\footnotetext{
a Schrader, F. C., Reconnaissance in northern Alaska: Prof. Paper U. S. Geol. Survey No. 20, 1904 p. 110.

bStoney, G. M., Naval explorations in Alaska, U. S. Naval Institute, Annapolis, 1900, p. 69.

- Schrader, F. C., op. cit., pp. 31 and 109.

$d$ Coal and lignite of Alaska: Seventeenth Ann. Rept. U. S. Geol. Survey, pt. 1, p. 818.

- Schrader, F. C., op. cit., pp. 74-76.
} 

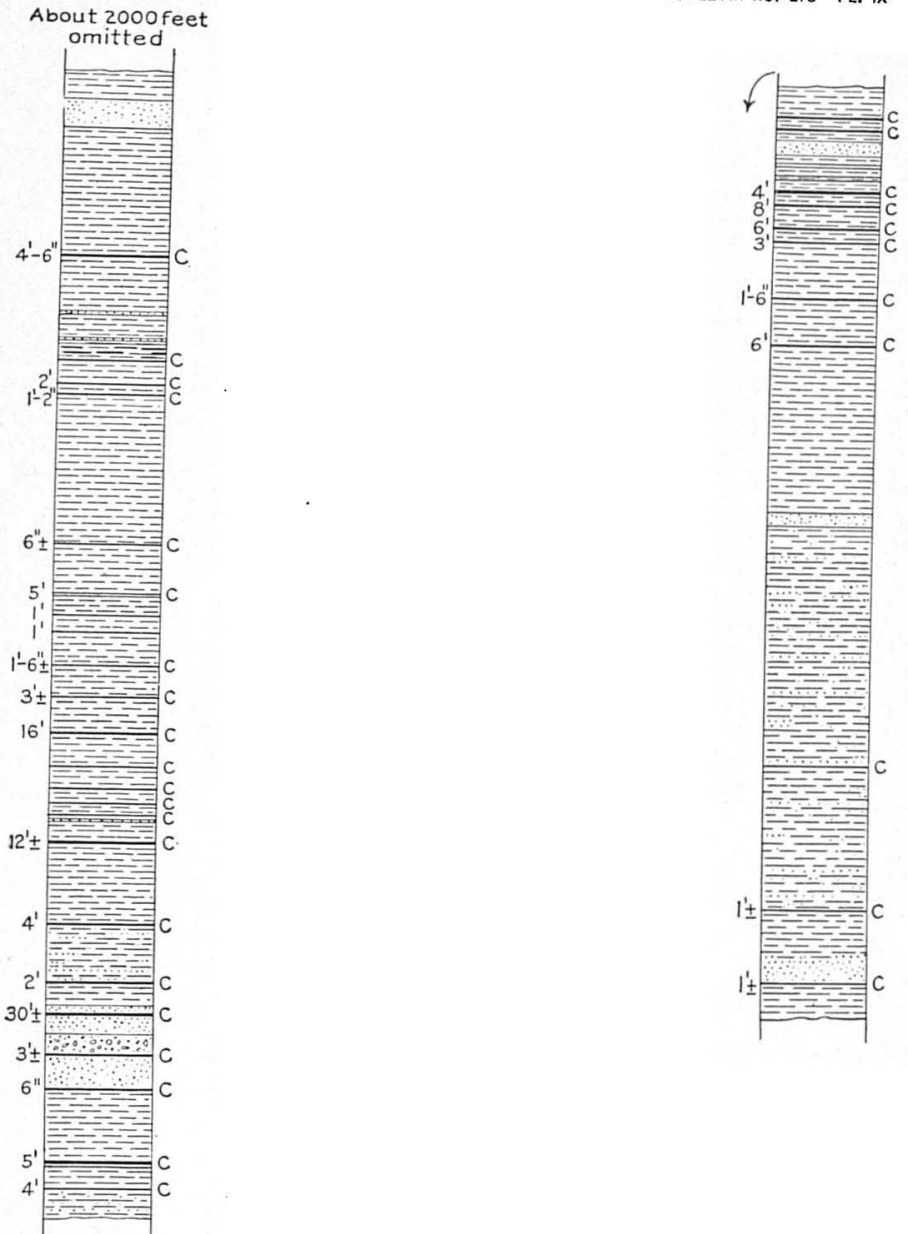

About 1500 feet
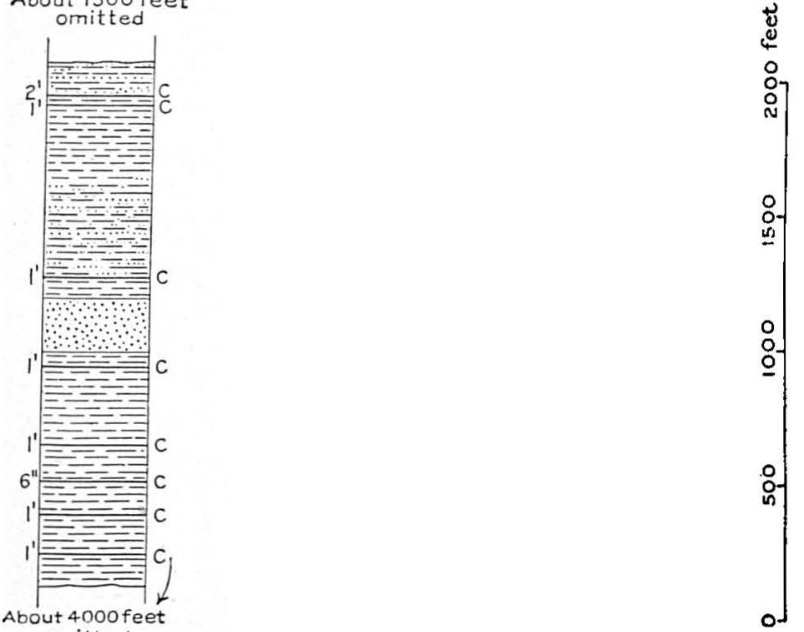

omitted 



\section{PALEOZOIC COAL FIELDS.}

EXTENT.

The Paleozoic coals of the Cape Lisburne region are of Lower Carboniferous age and occur in the rocks of the Carboniferous series, which has been described under the heading "Geology." The coal-bearing member is apparently near the bottom of the series. Owing to the complicated structure of the rocks of the Lower Carboniferous series, the coal-bearing formation outcrops in limited areas, whose inland extensions and outlines can be determined only by more detailed work than the time allowed this expedition.

The coal-bearing member outcrops in several small areas near the coast south of Cape Lisburne, on Kukpuk River, about 15 miles from the coast, and on the coast at Cape Thompson. The coal beds were not reported by any of the early explorers, and they have not been worked to any extent by whalemen. They were first recognized as distinct from the Mesozoic coals by A. G. Maddren, who visited one of the localities in 1900. $a$ Small amounts of the coal have been tested in galley stoves and a few tons have been mined for use at the Point Hope whaling station, but there have been no large amounts mined, nor have analyses been made previous to 1904 .

It is said to give a more intense fire than Nanaimo coal, but engineers of the revenue cutter Cormin regarded it as too hard to burn in furnaces not provided with forced draft.

\section{LOCALITIES IN DETAII.}

NIAK.

Four miles ${ }^{b}$ south of Cape Lisburne black coal-bearing shales outcrop for about half a mile in a cliff about 50 feet high back of a narrow beach. The locality, a famous camping place of the natives, is called Niak, and is near the mouth of a large creek from which vessels have occasionally taken water. On the south side the shales are in contact with the massive limestones which are faulted over them (see fig. 5, page 20). The outcrop of the formation extends inland in a southeast.direction, but its limits have not been determined. The shales are very much crumpled, and the inclosed coal beds are often sheared so that no continuous bed remains, but the coal occurs in lenticular masses along fault planes. Maddren reports seeing a 4 or 5 foot bed of coal whose outcrop extended across from the coast to the creek and which dipped north at an angle of $60^{\circ}$. Small amounts have been mined from the lenses noted above, and Mr. Washburne reports that he saw a pile of coal which was mined and sacked previous to 1904. A sample taken from these sacks was analyzed by W. T. Schaller with the following result:

Analysis of coal from Niak, 4 miles south of Cape Lisburne, Alaska.

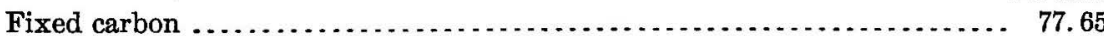

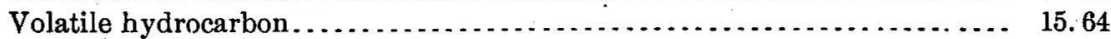

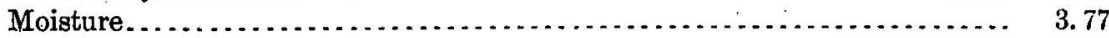

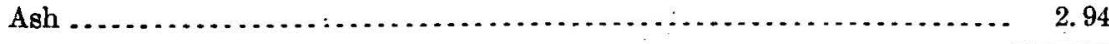

100.00

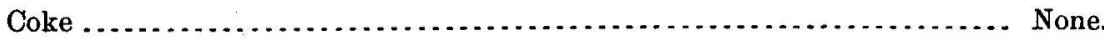

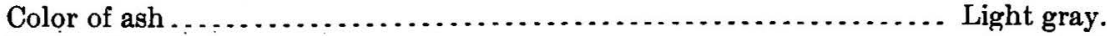

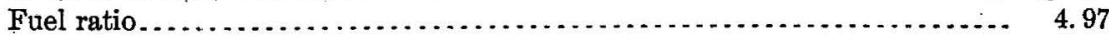

CAPE LEWIS.

About 1 mile south of Cape Lewis, which is a promontory nearly 1,000 feet high 11 miles south of Cape Lisburne, there is a second exposure of coal-bearing shales

a Schrader, F. C., Reconnaissance in northern Alaska: Prof. Paper U. S. Geol. Survey No. 20, p. 113. $b$ This description is based on the work of $C$. Washburne. The locality was not visited by the writer. 
which outcrop for half a mile in a low cliff back of the beach. These shales carry in addition to the coal abundant fossil plants of Paleozoic type. Beyond the short cliff no outcrops of coal have been observed, though there are occasional outcrops of black shale for 3 miles to Cape Dyer. The coal-bearing shales are overlain by thinly bedded limestones and black cherts and slates, which are in turn overlain by the massive limestones of Cape Lewis (see fig. 4, p. 19), and they appear to rest conformably on the massive sandstone of which Cape Dyer is composed.

The coal beds at this point have not been developed and have yielded no coal. Though only one bed of sufficient thickness to mine has been discovered, it is probable that a small amount of development would uncover several beds, some of which may be of sufficient size to work. Since the structure does not seem greatly complicated, the beds may be found to contain a considerable quantity of workable coal.

The outcrops which were examined are at a point about $1 \frac{1}{2}$ miles south of Cape Lewis. They are usually covered by talus from the cliff, but the locality can be exsily recognized, since it is the first rock exposure south of a creek about 1 mile south of the cape.

The upper bed of coal strikes $\mathrm{N}$. $75^{\circ} \mathrm{E}$. and dips north at an angle of $40^{\circ}$. It is 4 feet thick, but is considerably crushed, and only fine material can be obtained from the croppings. The seam has one small indistinct parting near the middle. It could not be traced back from the coast on account of a heavy covering of chert and limestone débris. The roof of the coal bed is hard gray fire clay, and the underlying beds are hard black fire clays or slates containing fossil plant remains. Two smaller beds, which could not be measured, outcrop south of this at intervals of about 50 yards. Their overlying and underlying beds are similar to those of the bed described above. A sample was taken by the writer across the whole face of the 4 -foot coal bed, which, when analyzed by W. T. Schaller, gave the following result:

Analysis of coal from beds 1 mile south of Cape Lewis, Alaska.

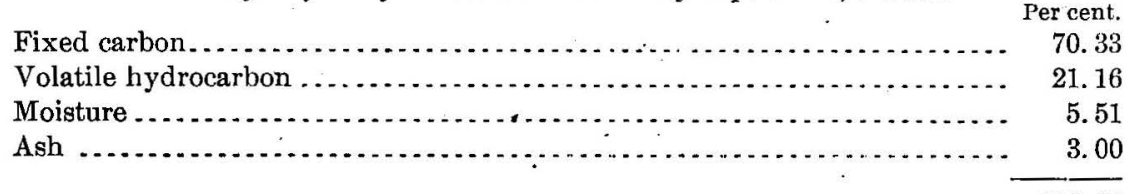

100.00

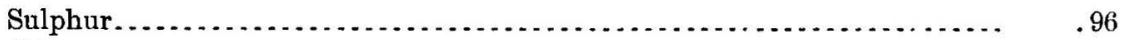

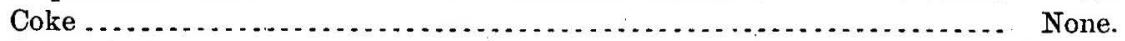

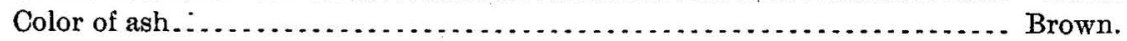

CAPE DYER.

$A$ third area of these coal-bearing rocks reaches the coast south of Cape Dyer, and the coal beds are exposed in a low cliff, which is nearly continuous from Cape Dyex to the high bluff called "The Ears," a distance of about a mile and a half. An abandoned native settlement here bears the name Capaloa, $a$ and the name is applied by the writer to the creek near which the old houses stand.

Cape Dyer is about 16 miles south of Cape Lisburne. Seen from the north it appears as an isolated butte standing out in the sea, the land back of it being much lower. The coal-bearing formation probably connects back of the high point with the above-mentioned area south of Cape Lewis.

The coal-bearing rocks consist of black shales and slates interbedded with limestone or hard, light-colored fire clay. At the north end of this exposure they overlie the massive sandstones of Cape Dyer with apparent conformity. At the south end the sandstones overlie the shales, the contact relation being a well-defined thrust fault. Where exposed in the cliff, the shales and interbedded limestones are very much

a According to Dr. John B. Driggs, missionary at Point Hope Capaloa is the native name for Cape Dyer as well as for the old village. 
crumpled and often fanlted, as is shown in fig. 3. S. J. Marsh reports that in 1900 a schooner on which he was a passenger obtained about a ton of coal here for use in the galley stove. There has been no development and there are no indications that the coals have been worked; moreover, development will be difficult and mining expensive on account of the disturbed condition of the beds. Coal beds outcrop at several places, but it is impossible to cletermine their number since some of them may be repeated. The largest bed seen measured 40 inches and dips to the south at an angle of $50^{\circ}$. The coal is more or less crushed and from the croppings only small. pieces can be obtained. Only one of the other beds presented a measurable exposure; this is a bed 1 foot thick aljout three-fourths mile south of Cape Dyer. The coal from this bed was obtained in large pieces. A sample taken by the writer across the large bed gave the following analysis:

\section{Analywis of roul coliected 1 mile south of Cape Iyyer, Alaska.}

Per cent.

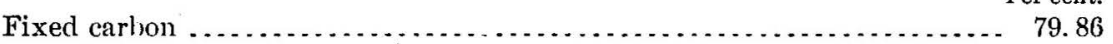

Volatile hydrocarbon ...................................... 15.62

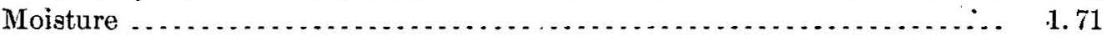

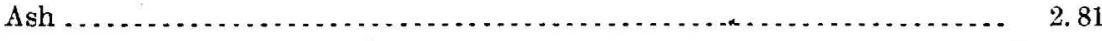

100.00

Coke....................................................... None.

Color of ash . . . . . . .

Fuel ratio . . . . . . . .

KUKPUK RIVER.

Coal beds probably of this formation outerop on Kukpuk River, about 15 miles from its mouth. These have not been examined by the writer, though the occurrence here of the coal-bearing formation was observed. Specimens of cannel coal of good quality are found on the beach at the mouth of the river, which may have been washed down, though their source in the bed rock has not been found and they may have come from either the Mesozoic or Paleozoic formations. If coal should be developed on this river, Marryat Inlet could be used as a shipping point for small cargoes.

CAPE THOMPSON.

Similar coals have been reported from Cape Thompson about 40 miles south of Cape Lisburne. The Carboniferous rocks are known to extend to Cape Thompson, and the cliffs when seen from a distance appear to contain shales similar to those of the coal formation, but the locality has not been examined by the writer.

INLAND EXTENSION OF PALEOZOIC COALS.

Nothing is definitely known of the occurrence of Carboniferous rocks beyond a point 15 miles from the sea on Kukpuk River. From clescriptions of Noatak River given by S. B. McLenigan " it seems possible that the crumpled shaly rocks of this series may be exposed at the canyon of the Noatak, which is about 120 miles east of Cape Thompson.

Carboniferous rocks correlated with the Lisburne formation were found by Schrader on the headwaters of John and Anaktuvuk rivers in 1901. No coal beds have been reported here, though it is possible that a more careful search may reveal the presence of the coal-bearing member. On upper John River in latitude $67^{\circ} 7^{\prime}$ north, longitude $152^{\circ}$ west, considerable coal detritus was observed. This was of such a quantity and character as to suggest the occurrence of bituminous coals of economic value somewhere in the region north of this locality and in the drainage basin of John River.

$a$ Cruise of the Corwin in 1885. Washington, Government Printing Office, 1887, pp. 72-73. 


\section{Character of CAPE LISBURNe coats.}

The coals of the Corwin formation which are most widely distributed in northwestern Alaska are of a rather low grade but considerably better than average lignite, though as a general rule they slack to a greater or less degree when exposed to the weather. They are all, so far as known, noncoking. The analyses made from samples collected from a number of beds in 1904 show that the average fuel ratio is about 1.22. The average percentage of water is below 10 , and the average percentage of ash is about 5. The sulphur, wherever it has been determined, is less than half of 1 per cent. The average specific gravity, which has not been carefully determined, is probably between 1.30 and 1.40 .

Mr. Chas. L. Norton, of the Massachusetts Institute of Technology, made the following report to the Corwin Trading Company on a sample of this coal: $a$

I find that the specimens of Alaska coal which you recently sent me have a calorific power of 7,560 calories per gram, or 13,600 B. T. U. per pound. This is quite as good as the average western coal and is not more than 10 per cent inferior to the best eastern coals. I can not guarantee the sampling of the coal, as I have had only a few small sample lots to work from. To guarantee the same I should have to select samples from several tons. I have made 28 combustions of the samples you sent me, and the figures given below are the average value.

Comparative values:

British thermal units.

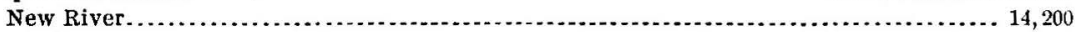

Alaska Corwin.............................................................. 13,600

No calorific tests have been made of the samples taken last summer though the proximate analyses which were made would seem to confirm the above results.

The coal.when used for steaming purposes on the ocean has not given perfect satisfaction on account of its too small specific gravity for the high-draft steamer furnaces and its high percentage of ash. The coal which was sold at Nome was found satisfactory for domestic purposes, except for its high percentage of ash and clinkers. That a large part of this dissatisfaction can be overcome by greater care in mining or by washing the coal after mining is evident from the two analyses which were made of washed and unwashed coal from the large bed at Corwin Bluff (see table, page 38). In this case the ash was reduced by washing from 11 to 4 per cent.

The coals of the Carboniferous series are noncoking and of a grade between bituminous and anthracite which should probably be classed as semibituminous. The average of analyses of samples from three widely separated localities give: Fixed carbon 75 per cent, moisture 3.66 per cent, and ash 3.95 per cent. The average fuel ratio is 4.32 . The only sample tested for sulphur gives 0.96 per cent. No tests for phosphorus have been made. None of the samples coked. These results indicate a very high-grade fuel containing very little refuse matter. The coal in all the beds sampled is considerably crushed and is usually in small pieces in the croppings, where it has probably been broken up to some extent, at least by free\%ing and thawing, but it does not slack perceptibly when exposed to the air. The specific gravity was roughly determined for two samples, and gave an average of 1.37 .

\section{ANALXSES OF COALS.}

The samples for analysis obtained last summer represent as nearly as possible the whole thickness of the beds from which they were taken. They were sealed up immediately in tin tubes to prevent any loss of moisture, and the analyses in most cases, therefore, show a higher percentage of moisture than the analyses published heretofore of coals from the Cape Lisburne region. The table which follows includes several analyses that have been published before as well as those made from samples collected by the writer.

a Brooks, A. H., Coal resources of Alaska: Twenty-second Ann. Rept. U. S. Geol. Survey, pt. 3,1902, p. 566. Schrader, F. C., Reconnaissance in northern Alaska: Prof. Paper.U. S. Geol. Survey No. 20, 1904 , p. 112. 
A second table is inserted for the purpose of comparing these coals with coals from other parts of Alaska and the United States. With the exception of the analyses of Vancouver Island and Washington coals in this table the samples and analyses are from recent work of geologists and chemists of the United States Geological Survey and of the coal-testing plant maintained at the Louisiana Purchase Exposition, $a$ and are as nearly as possible representative in every way of the mines from which they are taken.

No caloritic determinations for the coals from the Cape Lisburne region have been made. By the use of an empirical formula which the writer bas found to give approximately accurate results the average calorifie value of the Jurassic coals can be estimated at 7,000 calories or 12,200 British thermal units, and of the Carboniferons coals 7,715 calories or 13,887 British thermal units. The calorific values of coals from the United States, obtained by this formula, differ only slightly from those determined experimentally, while the calculated calorific value of the British Columbia coals is nearly 500 calories higher than that given in the table.

Table of proximate analyses of coals from the Cape Lisburne region, Alaska:

\begin{tabular}{|c|c|c|c|c|c|c|c|c|c|}
\hline Sample No. & Locality. & $\begin{array}{c}\text { Fix- } \\
\text { ed } \\
\text { car- } \\
\text { bon. }\end{array}$ & $\begin{array}{c}\text { Vola- } \\
\text { tile } \\
\text { hy- } \\
\text { dro- } \\
\text { car- } \\
\text { bon. }\end{array}$ & $\begin{array}{l}\text { Mois- } \\
\text { ture. }\end{array}$ & Ash. & $\begin{array}{c}\text { Sul- } \\
\text { phir. }\end{array}$ & $\begin{array}{l}\text { Fuel } \\
\text { ratio. }\end{array}$ & $\begin{array}{l}\text { Geologic } \\
\text { formation. }\end{array}$ & Analyst. \\
\hline & & Perct. & Perct. & Perct. & Perct. & Perct. & Perct. & \multirow[b]{2}{*}{ Corwin ... } & \\
\hline $4 \mathrm{~A} \mathrm{~W} 7 \ldots$ & $\begin{array}{l}\text { 17. miles west of } \\
\text { Corwin Bluff. }\end{array}$ & 40.80 & 41.30 & 13.55 & 4.35 & 0.40 & 0.96 & & W. T. Schaller. \\
\hline $4 \mathrm{AC} 1 \ldots$ & $\begin{array}{l}\text { mile west of Cor- } \\
\text { win Bluff. }\end{array}$ & 42.06 & 37.72 & 11.18 & 9.04 & 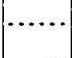 & 1.11 & . do . . & Do. \\
\hline $4 \mathrm{~A} \mathrm{C} 4 \ldots$. & $\begin{array}{l}\text { mile westof Cor- } \\
\text { win Bluff (un- } \\
\text { washed sample). }\end{array}$ & 41.67 & 37.49 & 9.45 & 11.39 & .30 & 1.11 & ..... do. & Do. \\
\hline 4 A C $5 \ldots$ & $\begin{array}{l}\text { t mile west of Cor- } \\
\text { win Bluff (wash- } \\
\text { ed sample). }\end{array}$ & 47.49 & 39.08 & 9.49 & 3.49 & $\ldots$ & 1.21 & ...do & $\begin{array}{l}\text { Do. } \\
\text { Do. }\end{array}$ \\
\hline $4 \mathrm{AC} 6 \ldots$ & Corwin Bluff....... & 57.49 & 34.59 & 4.49 & 3.43 & .39 & 1.63 & ....do.... & Du. \\
\hline $4 \mathrm{AC} 2 \ldots$ & $\begin{array}{l}\text { 1,000 feet east of } \\
\text { Corwin Bluff. }\end{array}$ & 48.47 & 33.40 & 12.45 & 5.68 & & 1.45 & ..... do. & Do. \\
\hline $4 \mathrm{AW} 20 \ldots$ & $\begin{array}{l}\text { Thetis mine, } 8 \\
\text { miles east of Cor- } \\
\text { win Bluff. }\end{array}$ & 46.27 & 35.60 & 13.61 & 4. 52 & & 1.30 & ....do. & Do. \\
\hline $653 b \ldots$. & $\begin{array}{l}\text { Near Wainwright } \\
\text { Inlet. }\end{array}$ & 42.94 & 42. 99 & 10.65 & 3.42 & .62 & .99 & .....do .... & George Steiger. \\
\hline $655 b \ldots$. & Cape Beaufort ..... & 51.23 & 36.38 & 7.18 & 5.21 & .48 & 1.40 & .....do... & Do. . \\
\hline $669 b \ldots$ & Corwin mines ..... & 46. 16 & 40.12 & 10.47 & 3.25 & .27 & 1.10 & ..... do .... & Do. \\
\hline $671 b \ldots \ldots$ & Corwin mines ..... & 50.05 & 38.68 & 7.23 & 4.04 & .23 & 1.30 & ..... do ${ }_{-} .$. & Do. \\
\hline $0 . . . \ldots \ldots . .$. & Corwin mines (?) .. & 47.39 & 43.75 & 3.75 & 5.11 & .36 & 1.08 & (?) & Albert H. Welles. \\
\hline & $\begin{array}{l}\text { A verage of coals } \\
\text { from Corwin } \\
\text { formation. }\end{array}$ & 46.83 & 38.42 & 9.46 & 5.24 & .38 & 1.21 & & \\
\hline $4 \mathrm{~A} \mathrm{~W} 42 \ldots$ & $\begin{array}{l}4 \text { miles south of } \\
\text { Cape Lisburne. }\end{array}$ & 77.65 & 15.64 & 3.77 & 2.94 & & 4.96 & $\begin{array}{l}\text { Carbonif- } \\
\text { erous. }\end{array}$ & W. T. Schaller. \\
\hline $4 \mathrm{~A} \mathrm{C} 24 \ldots$ & $\begin{array}{l}1 \text { mile south of } \\
\text { Cape Lewis: }\end{array}$ & 70.33 & 21.16 & 5. 51 & 3.00 & .96 & 3.32 & .....do.... & Do. \\
\hline 4 A C 31 . & $\begin{array}{l}1 \text { mile south of } \\
\text { Cape Dyer. }\end{array}$ & 79.86 & 15.62 & 1.71 & 2.81 & & 5. 11 & ... do. & Do. \\
\hline & $\begin{array}{l}\text { A verage of coals } \\
\text { from Lisburne } \\
\text { formation. }\end{array}$ & 75.94 & 17.47 & 3.66 & 2.92 & & 4.46 & & . \\
\hline
\end{tabular}

a Parker, E. W., Holmes, J. A., and Campbell, M. R., Preliminary report on the operations of the coal-testing plant: Bull. U. S. Geol. Survey No. 261, 1905.

$b$ Schrader, F. C., Reconnaissance in northern Alaska in 1901: Prof. Paper U. S. Geol. Survey

No. 20, 1904, p. 114. Coal resources of Alaska: Twenty-second Ann. Rept. U. S. Geol. Survey, pt. 3, 1902, p. 565 . 
Comparison of analyses of coal from the Cape Lisburne region with coals from other parts of Alaska and the United States.

\begin{tabular}{|c|c|c|c|c|c|c|c|}
\hline & $\left|\begin{array}{r}\text { Fixed } \\
\text { carbon. }\end{array}\right|$ & $\begin{array}{l}\text { Volatile } \\
\text { matter. }\end{array}$ & $\begin{array}{l}\text { Mois- } \\
\text { ture. }\end{array}$ & Ash. & $\begin{array}{l}\text { Sul- } \\
\text { phur. }\end{array}$ & $\begin{array}{c}\text { Fuel } \\
\text { ratio. }\end{array}$ & $\begin{array}{l}\text { Calo- } \\
\text { ries. }\end{array}$ \\
\hline $\begin{array}{l}\text { A verage of } 12 \text { analyses of Jurassic coals } \\
\text { from Cape Lisburne region.................... }\end{array}$ & 46.83 & 38.42 & 9.46 & 5.24 & 0.38 & 1.21 & \\
\hline $\begin{array}{l}\text { A verage of } 3 \text { analyses of Carboniferous coals } \\
\text { from Cape Lisburne region................... }\end{array}$ & 75. 94 & 17.47 & 3.66 & 2.92 & .96 & 4.46 & \\
\hline 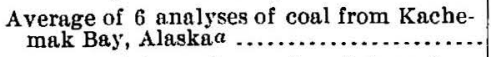 & 30.99 & 40.48 & 19.85 & 8. 68 & .35 & .76 & \\
\hline $\begin{array}{l}\text { Average of } 12 \text { analyses of coal from Con- } \\
\text { troller Bay, Alaska } b \ldots \ldots \ldots \ldots \ldots \ldots \ldots \ldots \ldots . . .\end{array}$ & 75.65 & 15.07 & 1.31 & 7.97 & 1.25 & 5.15 & \\
\hline $\begin{array}{l}\text { Average of } 13 \text { analyses of commercial coals } \\
\text { from Vancouver Island } c \ldots \ldots \ldots \ldots \ldots \ldots \ldots\end{array}$ & 55.72 & 31.57 & 1.54 & 10.24 & .83 & 1.76 & 6,775 \\
\hline $\begin{array}{l}\text { A verage of } 10 \text { analyses of coal from the State } \\
\text { of Washington } d . \ldots \ldots \ldots \ldots \ldots \ldots \ldots \ldots\end{array}$ & 56.01 & 31.60 & 4.43 & 7.45 & & 1.45 & \\
\hline $\begin{array}{c}\text { A verage of } 12 \text { analyses of coals from West } \\
\text { Virginia } e^{2} \ldots \ldots \ldots \ldots \ldots \ldots \ldots \ldots \ldots \ldots \ldots \ldots \ldots\end{array}$ & 63.94 & 27.63 & 2.25 & 6.17 & 1.09 & 2.31 & 7,982 \\
\hline Average of 6 analyses of coals from Illinois $e$. & 42.56 & 35.23 & 7. 61 & 12.90 & 3. 02 & 1.20 & 6,296 \\
\hline A verage of 2 analyses of lignites from Texas $e$ & 23.41 & 36.49 . & 30.72 & 9.38 & .53 & .64 & 4,181 \\
\hline $\begin{array}{l}\text { Average of } 2 \text { analyses of lignites from } \\
\text { North Dakota }\end{array}$ & 36.55 & 37.91 & 16.06 & 9.47 & 1.32 & .96 & 5,153 \\
\hline
\end{tabular}

$a$ Stone, R. W., Kachemak Bay coal fields: Bull. U. S. Geol. Survey No. 277. (In preparation.)

$b$ Martin, G. C., Progress report of the division of Alaskan mineral resources for 1904: Bull. U. $\mathrm{S}$. Geol. Survey No. 259, 1905, p. 149.

cAnnual report of the Minister of Mines, 1902. Victoria, B. C., Wolfenden, 1903, p. H-262.

dSmith, G. O., Coal fields of the Pacific Coast: Twenty-second Ann. Rept. U. S. Geol. Survey, pt. 3, 1902 , p. 490 .

$e$ Parker, E. W., Holmes, J. A., and Campbell, M. R., Preliminary report of the uperations of the coal-testing plant: Bull. U. S. Geol. Survey No. 261, 1905, pp. 32-59.

\section{CONDITIONS OF MINING AND DEVELOPMENT.}

There are no permanent developments or conveniences of mining at any of the places in the Cape Lisburne region where coal has been obtained. When the mines were operated by the whaling fleet the ships anchored near and sent sailors ashore to dig coal from the croppings wherever it was convenient. Sometimes powder was used to break down the face of the cliff, after which the coal could be picked out of the débris. In 1900 and 1901 the Arctic Development Company and the Corwin Trading Company attempted to mine a little more systematically, but as the work was largely done by Eskimos and directed by men inexperienced in coal mining, it is doubtful whether the product fairly indicated what the mines would produce if properly exploited. All black rocks were probably sacked up and sent on board.

Since 1900 a few white men remaining at Corwin Bluff have attempted to work the coal beds during the winter by short tunnels driven in from the face of the sea cliff, but the results have been unsatisfactory, since the entrances to the mines and the coal produced were covered by snowdrifts which turned to ice and made them inaccessible when the ships arrived in the summer.

The development of the coal beds at Corwin Bluff from some point back of the cliff would be easy on account of their perfect regularity, and there is no reason why mines developed in this way could not be worked all winter.

Coal mined and sacked in winter would be available for shipment in summer if piled on the level ground above the cliffs or at places near sea level where the cliffs are lower and snowdrifts do not form. There are two such places convenient to Corwin Bluff, with good beaches before them for landing. In fair weather coal could probably be loaded on vessels by means of a cable tramway from the top of the cliff, but the experience gained at Nome would seem to indicate that in the long run it would be less expensive to lighter it from the beaches. This work can probably be done more easily at Corwin Bluff than at Nome, because ships can anchor much nearer the shore. 
During the summer months only calm days can be used for boating coal off to the ships. Strong north or northeast winds make landings impossible, and strong south winds also make the work difficult. During thirty days from July 22 to August 22, 1904, there were thirteen days during which the surf was too high for landing and several more when strong south winds would make the use of a line necessary.

The high-grade bituminous coals of the Carboniferous formation south of Cape Lisburne occur in limited areas and in rocks that are very intensely folded, so that the beds are irregular and the cost of mining will necessarily be greater than at Corwin Bluff. The character of the coal, however, will probably justify their development at some time in the future. The conditions for shipping coal are better than at Corwin Bluff, since vessels can find deep water nearer shore and the anchorage is sheltered from northeast winds by the Lisburne Hills. The force of the sea from south winds also is broken by the Point Hope peninsula. Should any of these deposits be developed enough to justify it, they could be connected by a short railroad with Marryat Inlet, a good harbor for small vessels, where wharves and bunkers can be maintained.

The coals from this region can not compete with outside coal at Nome since the latter is sold there as low as $\$ 15$ per ton, which is less than the cost of shipping from the Cape Lisburne region. A limited amount of coal at either of the localities mentioned along the coast would probably find a ready sale to whaling ships and revenue cutters at not less than $\$ 10$ per ton, and a larger amount could doubtless be disposed of in the mining camps about Kotzebue Sound. Coal from outside sources has probably never been sold at Kotzebue Sound for less than $\$ 30$ per ton. The whole amount of coal which could be marketed from the Cape Lisburne region at present is probably between 500 and 1,000 tons annually.

\section{SUMMARY OF FCONOMIC GEOLOGY.}

The coals of the Cape Lisburne region are of two distinct classes-low-grade bituminous coal of Mesozoic age and high-grade bituminous or semibitumous coal of Paleozoic age.

The Mesozoic coal fields are known to cover an area of about 300 square miles, but reports obtained from prospectors and others indicate that their extent may be much greater. The coal-bearing formation is of great thickness and contains at least 150 feet of coal distributed in from 40 to 50 seams, no less than 10 of which are over 4 feet thick and seem to be suitable for mining. The geologic structure of the formation is simple and well adapted to mining, and the greatest obstacle will be the absence of timber in the region. The coal is a low grade of bituminous, but considerably better than lignite. Vessels of the whaling fleet and revenue cutters have for the last twenty-five years occasionally obtained a supply from the croppings of the seams in the sea cliffs near Corwin Bluff, and in 1900 and 1901 over 1,000 tons were mined and sold at Nome for $\$ 18$ to $\$ 25$ per ton in competition with Washington and British Columbia coals. It has not given as much satisfaction as that from Washington and British Columbia. Although it produces steam rapidly, it is not lasting and leaves too large a percentage of clinker and ash. This result is no doubt partly due to the unsystematic manner of mining from natural croppings in the cliffs, and if the beds were properly developed in depth and the coal carefully mined to exclude unnecessary refuse it would probably give fair results for steaming purposes. A limited amount of coal, if it could be relied on, at Corwin Bluff would find a ready sale to whalemen and vessels of the Revenue-Marine Service at not less than $\$ 10$ delivered on the beach. At present these Mesozoic coals can not compete at Nome with those from the outside, but in the mining camps of the northern portion of Seward Peninsula, where outside coal rarely sells for less than $\$ 30$ per ton, about 1,000 tons from Corwin Bluff could probably be easily disposed of. Should future development of

Bull. 278--06-4 
Alaska or of the commercial activities of the world create such a demand for coal of this character as to justify the building of a railroad to the region, the supply will probably be found sufficient for many years' use.

The Paleozoic coals of the region occur in limited areas and the beds are very much crumpled and broken. The largest bed seen is not over 4 feet thick, but the coal is of a high grade, suitable for special purposes, such as blacksmithing and metallurgy, and will probably compare favorably as a heat producer with any coal used on the Pacific coast. These coals are also undeveloped and on account of their complicated geologic structure they will be more difficult to mine than the Mesozoic coals.: On the other hand, the anchorages south of Cape Lisburne are protected from northeast and south winds, and deep water can be found nearer shore than at Corwin Bluff. The localities are also convenient to Marryat Inlet, which is a good harbor for vessels of less than 10 feet draft: On account of their good quality these coals could probably be sold at a profit even in the Nome market, where the best outside coal still commands a price of $\$ 30$ per ton. It is therefore safe to say that the Paleozoic coals of the Cape Lisburne region warrant investigation, and it is not unreasonable to expect that in the future their exploitation will contribute an appreciable addition to the value of the mineral output of Alaska. 


\section{N D E X.}

A.:

Page.

Agate Rock at Cape Thompson, view of ... Anaktuvuk River, elevations along........ Analyses of coals.

Animals, kinds of

Aretic Development Company, mining attempted by....

Arctic Ocean, depths, currents, and ice packs of ................... 10-11

Arctic Slope province, description of....... 14 rocks of ........................ 27

Aviculopecten, occurrence of ........... 18

\section{B.}

Barrier beaches, occurrence and cause of.. Belcher, _ , fossils collected by 21,22 Bertholf, E. P., on population of Point Hope Birds, kinds of Broals, submarine topography near Breccia, fault, occurrence of

Brooks, A. H., on Carboniferous rocks ..... on coals of Queen Charlotte Island.... on Cretaceous rocks

on Devonian rocks ....................

on Lisburne limestones................. on Mesozoic beds on rocks of upper basin of White River. Buckland, william, fossils determined by.. 22, 23

\section{C.}

Calcite, oceurrence of $\ldots \ldots \ldots \ldots \ldots \ldots \ldots \ldots, 17,21$

Call, S. J., Jr., acknowledgment to......... 21

Cape Beaufort, coal at................... 6,41

coal at, analysis of ................... 47

Corwin formation at................... $\quad 27$

fossil plants collected at.............. 28

location and features of .............. 10

Cape Chibukak, topography of shore at.... 34

Cape Dyer, coal near ................... 44-45

coal near, analysis of ................ 45,47

coal section between the Ears and ..... 19

fault near, figure showing .............. 19

fossil plants collected near ............. 22

native name for ................... 44

pre-Carboniferous rocks near, jointing and cleavage in, figure showing.

Cape Lewis, Carboniferous formations south of, figure showing ..............

Carboniferous rocks north of, faults in. coal near analysis of
Cupe Lewis, coal beds at examination fossil plants from..... fossil invertebrates collected near ..... 23, 24 location of........................... 8

Cape Lisburne, coals near, analyses of ..... 47, 48 coals near, calorific value of .......... 47 discovery and naming of.............. 6

folded beds and thrust fault near, view of ......................... 20 fossils colleated at and near........ 6, 22, 23 limestone outcrops at, view of......... 18 Cape Prince of Wales, investigation at.... 8 Cape Sabine, coal beds near.............. 41,42 location and features of ............... 10

Cape Thompson, Agate Rock at, view of.... 20

Carboniferous rocks at................ 18

cliffs at, section in.................... 21

coal at............................. 43,45

description of ....................... 9

fossils collected at.................... 6, 22

settlement near...................... 13

Carboniferous conl formations, sections of.. 19

Carboniferous rocks, distribution, character, and thickness of....... 16,18-27,31,45 near Cape Lewis, thrust faults in...... 20 Chichagof Island, fossils from............ $\quad 26$ Climate, features of ................... 11

Coal, analyses of ...................... 46-48 analysis of, from Cape Beaufort....... 47 from Cape Dyer .................. 45, 47 from Cape Lewis ................. 44,47 from Cape Lisburne ............... 47 from Corwin Bluff......... 37, 38, 39, 40, 47 from Corwin mines............. 47 from Niak ..................... 43 from Thetis mine...............41,47 from United States and Alaska, comparison of ................ 48

from Wain wright Inlet........... 42,57

calorific value of ...................... 47

character of .......................... 5,46

discovery of ........................ 6

geologic horizons of ................. 5,35

Coul, cannel, occurrence of .............. 45

Conl, Carboniferous, from Cape Lisburne region, average analysis of .... 48

Coal, Jurassic, from Cape Lisburne region, average analysis of ............. 48

Coal, Paleozoic, age of................... 43

character and distribution of....... 43-45, 50

inland extension of .................. 45

Coal-bearing formations, ages of ........... 5,35

Coal bed at Corwin Bluff, view of ......... 40 
Coal beds, examination of................. $\quad 8,9$ fossils of ........................... $35-36$ Coal beds, Mesozoic, character and distribution of ...................... 37-43

Coal beds, Paleozoic, character and distribution of

Coal fields, location and accessibility of.... 5

Coast line, description of................ 9-10

Collie, A., conl discovered by .............. 6 fossils collected by ................. 21,22, 28 on coal bed at Cape Beaufort........... 28,41

Collier, A. J., fossils collected by........ 22, 26, 29 on Carboniferous fossils ................ 26 on Carboniferous rocks................ 18 on Ievonian rocks ................... 18, 26 on Permian series on the Yukon ....... 27 on Rampart formation ................ 18 on rocks on Charlie River............... 31

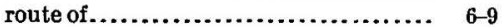

Colville River, coal on ................... $\quad 42$

Colville River basin, topography of upper. . $\quad 42$

Controller Bay, coal from, average analysis

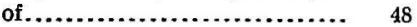

Cook, James, Captain, discovery and naming of Cape Lisburne by........

Copper River basin, Carboniferous rocks in.

Coopers whaling station, buildings near. .

Corwin (steamship), chartering of.........

Corwin Bluff, cliffs west of, view of......... cogl at and near, anglyses of $37,38,39,40,47$ coal beds at and near ................. 37-40 location and general features of..... $6,10,13$ Mesozoic rocks at.................. 27, 28, 30 population of....................... 13 section at, figure showing............. 39

Corwin coal field, map of part of........... 38

Corwin formation, character, thickness, and distribution of............. 16, 27-30

conls in .............................. 36

columnar section of .................. 42

fossils of ..................... 27, 28, 29-30

Corwin group, coal beds of, distribution and character of .................. $37-10$

Corwin mines, coal at, analyses of ........... 47

Corwin Trading Company, mining at tempted by

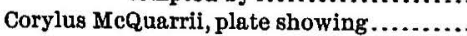

Cretaceous rocks, occurrence of .............

thickness and character of .

\section{D.}

Dall, W. H., on coal bed at Cape Beaufort .. on coal on Colville River.

on occurrence of ozocerite.

Dall, W. H., and Harris, G. D., on Pleistocene deposits.

.. 32,33

Development and mining, conditions of.... 48-49

Devonian rocks, distribution, thickness, and character of .............. 16,17-18

jointing and cleavage in, figure showing

Drainage of the region.

Driggs, J, B., on native name for Cape Dyer.

15

\section{E.}

Page.

Ears (The), coal section between Cape Dyer and

location of .......................... 13

Edge, Joseph, acknowledgment to ......... 9

work of................................

Elephas primigenius, discovery of teeth and tusks, of ..................... 33

Endicott Mountains, elevation of ........... 14

Explorations of the region............... 5, 6

F.

Fault, thrust, near Cape Dyer, figure show-

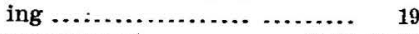

Faulting, occurrence of ........... 18, 19,20,31

Fickett formation, thickness and character of...................... 26

Fisher, - , fossils collected by .............. 6

Folding and faulting, view showing ....... $\quad 20$

Fontaine, W. M., fossils explained by...... 28

Fossil invertebrates, report on........... 22-26

Fossil plants, character of ................ $35-86$ collection of....................... 8

occurrence of........................ 27

plates showing ..................... 22, 32

reports on ....................... 22,29-30

Fossils, occurrence of....... $6,18,21,25-26,27,31$

G.

Geography of the region................ 9-16

Geology of the region................... 16-34

Geology, economic, account of ............. 35-49 summary of ...................... 49-50

Ginkgo adiantoides, plate showing ........ 32

Ginkgo Huttoni, plate showing ............. 22

Girty, G. H., acknowledgment to .......... 9 on fossils from Cape Thompson ........ 21 on fossils from Chichagof Island ....... 26 report on fossil invertebrates.......... 22-26

Gold, discovery of, at Nome ............... 6 occurrence of........................ 5,35

Grewingk, C., examination of fossils by ... 6, 22 Ground ice, character of .................

\section{H.}

Hackman, John, acknowledgmént to....... Hamlet, O.C., Capt., acknowledgment to...

Harris, G. D., and Dall, W. H., on Pleistocene deposits............... 32, 33

Hess, F. L., and Prindle, L:M., on Carboniferous fossils south of Yukon Flats ........................

on rocks of the Rampart region........ 18

History and explorations of the region .... 6

Hooper, C. L., on animals.................. 11

Howard, W. L., on coal on Colville River .. 24

Hutchinson, C. J., acknowledgment to .... 9

work of........................... $7,8-9$

Hyatt, Alpheus, on fossils from Cape Thomp-

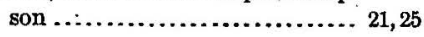

I.

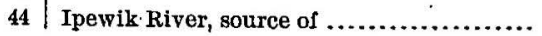


J.

Page.

Jabbertown, location of .

whaling station at, view of.

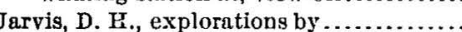

on climate.

on harbors.

on ice packs

packs and currents in the Arctic

Oceall

on route from Kotzebue Sound to Iey Bay..........................

on route of Point Barrow Relief Expedition ........................

John River, conl detritus on...............

Jura-Cretaceous rocks, occurrence of.......

Jurassic rocks, thickness, character, and distribution of ............ 16,27-30

K.

Kachemak Bay, coal from, average analy-

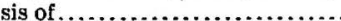

Kelly, .J. w., exploration by................

Kenai (Eocene) formation, Tertiary plunts from, view of ..................

Kivalina River, coal found on.............

Knowlton, F. H., acknowledgment to.....

report on Mesozoic fossil plants ........ 29-30

Koenig, H., acknowledgment to .......... 9,11

Kotzcbue Sound, location of ................ settlements on

Koyukuk River, rocks on .................

Koyukuk series, charncter of...............

Kuk River, coal on .......................

Kukpowruk River, source and course of ...

Kukpuk River, coal on.............. 43,45

delta of ........................... 33-34

recent deposits in ................ 33

description of ...................... 14

fossil invertebrates collected on........ 24

rocks on ........................... 17,21

Kupreanoff, I. A., fossils collected by .......

L.

Lagoons, occurrence of . .

Lepidodendron spetsbercense, plate show lng

Lesquereux, Leo, fossil plants determined

Limestoneoutcrops at Cape Lisburne, view of ............................

Lisburne formation, character, thickness, structure, and distribution of.. 16, 21-26

Lisburne Hills, description of .............. 13-14

rocks composing...................... 17, 18

Lopp, W. T., route followed by ........... 16

Lower Carboniferous rocks, thickness and character of

Lower Cretaceous rocks, thickness and character of .

M.

McLenigan, S. B., on Noatak River........ Maddren, A. G., on ground-ice formation. Paleozoic coals distinguished from Mesozoic by

Marsh, S. J., on coal from Cape Dyer........
Martin, G. C., on Jurassic rocks of Alaska Peninsula ................... 30 Narryat Inlet, location and features of .. 10,13,15 use of, as shipping point for coal...... 45 Mendenhall, W. C., and Schrader, F. C., on rocks in Copper River basin .... 27

Mesozoic coal field, extent of beds of.... 36,37-43 Mesozoic formations, character and distribution of ................... 27-31

Mesozoic plants, plates showing ........... 22

Mesozoic series, folded beds and thrust fault in, view of ............... 20

Mining and development, conditions of ... 48-49

Mississippian rocks, thickness and character of ......................... 16

Moffit, F. H., on settlements on Kolzebue Sound

Mlount Hamlet, location and gltitude of ....

Mount Kelly, location and elevation of.... 14

N.

Native villages, location of............... 12

Newberry, J. S., fossil plants determined

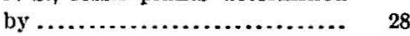

Niak, coal at coal at, analysis of ..................... 43

Noatak River, Carboniferous rocks on ..... 45 timberon............................ 5

Nome, coal used at, quantity and price of.. $\quad 49$ gold at, discovery of.................. 6

Norton, C. L., analysis by, of coal of the Corwin formation.................

o.

Ozocerite, probable occurrence of...........

\section{P.}

Pacific seaboard, rocks of

Paleozoic coal fields, description of ........ 43-45

Paleozoic formations, occurrence and character of ................... 16, 17-27.

Paleozoic plants, plate showing........... 22 Permian series, occurrence and charucter of.......................... 27

Pitmegen River, description of ............. 15 gold-bearing veins reported on........ 35 ground ice on ...................... 32-33 Placer gold-mining districts, location of .... 5 Plants, occurrence of.................... $\quad 11$

Plants, fossil, character of ............... 35-36 occurrence of .................. 27, 28, 29-30 plates showing ...................... 22, 32 reports on ...................... 22,29-30

Pleistocene deposits, distribution, thickness, and character of....... 16, 32-33 deposition of ........................ 14 Podozamites angustifolius, plate showing.. $\quad 22$ Podozamites lanceolatus, plate showing ... $\quad 22$ Point Hope, calcite vein near............. 17 climate at ............................ 11 location of.......................... 5,9 Point Hope peninsula, recent deposits on.. 33 settlements and population of.......... 12-13 topography of ...................... 13 whaling station at, view of............. 18

45 . Point Lay, location of.................. 10 
Populus arctica, plate showing Page

Prindle, L. M., and Hess, F. L., on Carboniferous fossils south of Yukon Flats

on rocks of the Rampart region .......

\section{Q.}

Quaternary deposits, distribution and character of 31-34

R.

Rampart formatiou, occurrence and character of

Ray, P.H., on native name for Point Hope. Recent deposits, distribution, thickness, and character of .............. 16, 33-34

Reed, J. S., coal beds reported by ........ 42 Routes of travel, location of............. 16

\section{S.}

St. Lawrence Island, Carboniferous rocks on ...........................

Schaller, W. T., acknowledgment to ....... analyses of coal by ... $37,38,39,40,41,43,44,47$

Schrader, F. C., cxplorations by.......... 6 formation named by ................. 21

fossils collected by $\ldots \ldots \ldots \ldots \ldots \ldots \ldots .25,28$

on Carboniferous rocks........... 18, 21, 26

on coal bed at Cape Beaufort ........ 41

on Corwin formation.............. 27, 28

on Cretaceous rocks................. $\quad 31$

'on fossil plants at Wainwright Inlet ... 42

on fossils on John and Anaktuvuk rivers........................

on Koyukuk series ...................

on Lisburne formation ...............

on rocks on Colville and Anaktuvuk rivers .................... 18, 31

on topography along Colville and Anaktuvuk rivers

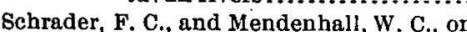
rocks in Copper River basin...

Schuchert, Charles, fossils determined by . 22,25 on fossils at Cape Beaufort ............ 28 on fossils from Cape Thompson ........ 21

Sequoia Langsdorfi, plate showing ........ 32 Settlements, location and character of..... 12-13 Seward Peninsula, Carboniferous rocks on . 26 mines on, fuel supply of............... 6 rocks on .......................... 17-18

Silurian rocks, occurrence of............. 17-18 Smith, E. E., on population of Point Hope. 12 Sphenopteris frigida, plate showing........ Spurr, J. E., on Permian series on the Yukon..

on rocks of the Rampart formation Steiger, George, analysis of coal by Steiger, George, analysis of coal by ........ stockton, C. H., on explorations in northerm Alaska.

on gold-bearing veins on PitmegeaRiver on ground-ice formation on Pitmegea River ........................ 32-33

on population of village at Cape Thomp-

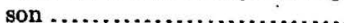

Stratigraphy, table showing.

mation, plates showing ........

Tertiary sediments, occurrence of..........

Thetis Creek, description of ..............

Pleistocene deposits near, description of

Thetis Creek basin, examination of .........

Thetis group, coal beds of, distribution and character of

Page.

Taxodium distichum miocenum, plate showing ....................

hetis mine, coal from, analysis of ......41,47

location of ......................... 6

Thompson, W., coal found by ........... 42

Thrust fault and folded beds, view of ...... 20

Tigara, location and population of ...... 9, 12,13

Timber, occurrence of................. 5

Topography, character of .............. 13,15

Triassic rocks, occurrence of ............ $\quad 30$

Tuckfield, Joseph, acknowledgment to .... 9 whaling station owned by ............ . 12

U.

Upper Jurassic rocks, thickness and character of .................. 16 Utukok River, description of ............ 15, 16

$\mathbf{V}$

Vegetation, character of ............ 5, 11, 32

Villages, native, location of ............ 12

W.

Wainwright Inlet, coal at. ............ $41-42$ coal at, analysis of . . . . . . . . . . . . . . 42,47

Corwin formation at ................ 27

fossil plants collected at.............. $\quad 28$

Ward, L. F., fossils determined by ........ 28

Washburne, Chester, acknowledgment to.. 9

on coal at Niak.................... 43

work of ..................... 6,8

Washington, coal from, average analysis of. $\quad 48$

West Virginia, coal from, average analysis of........................ 48

Wevok, fossil invertebrates collected near. 23,24 location of ........................ 8,13

Whales, method of killing............. 12

Whaling station at Jabbertown, view of ... 18

Whaling stations, location of............ 12

White, David, acknowledgment tc....... 9

fossils determined by............... $\quad 22$

report on fossil plants by ............ 22

Woolfe, H. D., collections of fossil plants made by.

exploration by $. . . \ldots \ldots \ldots \ldots . . . . . . .$.

on occurrence of coal at Wainwright Inlet.................... 12

on population of Point Hope......... ' 14

$\mathbf{Y}$.

Yukon River basin, Carboniferous rocks in.

Rampart formation in. 


\section{CLASSIFICATION OF THE PUBLICATIONS OF THE UNITED STATES GEOLOGICAI. SURVEY.}

[Bulletin No. 278.]

The serial publications of the United States Geological Survey consist of (1) Annual Reports, (2) Monographs, (3) Professional Papers, (4) Bulletins, (5) Mineral Resources, (6) Water-Supply and Irrigation Papers, (7) Topographic Atlas of United States-folios and separate sheets thereof, (8) Geologic Atlas of the United States-folios thereof. 'The classes numbered 2, 7, and 8 are sold at cost of publication; the others are distributed free. A circular giving complete lists may be had on application.

Most of the above publications may be obtained or consulted in the following ways:

1. A limited number are delivered to the Director of the Survey, from whom they may be obtained, free of charge (except classes 2, 7, and 8), on application.

2. A certain. number are delivered to Senators and Representatives in Congress, for distribution.

3. Other copies are deposited with the Superintendent of Documents, Washington, D. C., from whom they may be had at practically cost.

4. Copies of all Government publications are furnished to the principal public libraries in the large cities throughout the United States, where they may be consulted by those interested.

The Professional Papers, Bulletins, and Water-Supply Papers treat of a variety of subjects, and the total number issued is large. They have therefore been classified into the following series: A, Economic geology; B, Descriptive geology; C, Systematic geology and paleontology; D, Petrography and mineralogy; E, Chemistry and physics; F, Geography; G, Miscellaneous; H, Forestry; I, Irrigation; J, Water storage; $\mathrm{K}$, Pumping water; L, Quality of water; M, General hydrographic investigations; $\mathrm{N}$, Water power; $\mathrm{O}$, Underground waters; $\mathrm{P}, \mathrm{Hydrographic}$ progress reports. This paper is the sixty-sixth in Series $A$ and the eighty-second in Series B, the complete lists of which follow ( $\mathrm{PP}=$ Professional Paper; $\mathrm{B}=$ Bulletin; WS=Water-Supply Paper):

\section{SERIES A, ECONOMIC GEOLOGY.}

B 21. Lignites of Great Sioux Reservation: Report on region between Grand and Moreau rivers, Dakota, by Bailey Willis. 1885 . 16 pp., 5 pls. (Out of stock.)

B 46. Nature and origin of deposits of phosphate of lime, by R. A. F. Penrose, jr., with introduction by N. S. Shaler. 1888 . $143 \mathrm{pp}$. (Out of stock.)

B 65. Stratigraphy of the bituminous coal field of Pennsylvania, Ohio, and West Virginia, by I. C. White. 1891. 212 pp., 11 pls. (Out of stock.)

B 111. Geology of Big Stone Gap coal field of Virginir and Kentucky, by M. R. Campbell. 1893. 106 pp., 6 pls. (Out of stock.)

B 132. The disseminated lead ores of southeastern Missouri, by Arthur Winslow. 1896. 31 pp. (Out of stock.)

B 138. Artesian-well prospects in Atlantic Coastal Plain region, by N. H. Darton. 1896. 228 pp., 19 pls.

B 139. Geology of Castle Mountain mining district, Montana, by W. H. Weed and L. V. Pirsson. 1896. $164 \mathrm{pp} ., 17 \mathrm{pls}$.

B 143. Bibliography of clays and the ceramic arts, by J. C. Branner. $1896.114 \mathrm{pp}$.

B 164. Reconnaissance on the Rio Grande coal fields of Texas, by T. W. Vaughan, including a report on igneous rocks from the San Carlos coal fleld, by E. C. E. Lord. 1900.100 pp., 11 pls. (Out of atock.) 
B 178. El Paso tin deposits, by W. H. Weed. 1901.15 pp., 1 pl.

B 180. Occurrence and distribution of corundum in United States, by J. H. Pratt. 1901.98 pp., 14 pls. (Out of stock; see No. 269.)

B 182. A report on the economic geology of the Silverton quadrangle, Colorado, by F. L. Ransome. 1901. $266 \mathrm{pp}, 16 \mathrm{pls}$. (Out of stock.)

$B$ 184. Oil and gas fields of the western interior and northern Texas Coal Measures and of the Upper Cretaceous and Tertiary of the western Gulf coast, by G. I. Adams. 1901. 64 pp., 10 pls. (Out of stock.)

B 193. The geological relations and distribution of platinum and associated metals, by J. F. Kemp. 1902. 95 pp., 6 pls.

B 198. The Berea grit oil sand in the Cadiz quadrangle, Ohio, by W. T. Griswold. $1902.43 \mathrm{pp} ., 1 \mathrm{pl}$. (Out of stock.)

PP 1. Preliminary report on the Ketchikan mining district, Alaska, with an introductory sketch of the geology of southeastern Alaska, by A. H. Brooks. 1902.120 pp., 2 pls.

B 200. Reconnaissance of the borax deposits of Death Valley and Mohave Desert, by $M$. $R$. Campbell. 1902. 23 pp., 1 pl. (Out of stock.)

B 202. 'Tests for gold and silver in shales from western Kansas, by Waldemar Lindgren. 1902.21 pp. (Out of stock.)

PP 2. Reconnaissance of the northwestern portion of Seward Peninsula; Alaska, by A. J. Collier. 1902. 70 pp., 11 pls.

PP 10. Reconnaissance from Fort Hamlin to Kotzebue Sound, Alaska, by way of Dall, Kanuti, Allen, and Kowak rivers, by W. C. Mendenhall. 1902.68 pp., 10 pls.

PP 11. Clays of the United States east of the Mississippi River, by Heinrich Ries. 1903.298 pp., 9 pls. PP 12. Geology of the Globe copper district, Arizona, by F. L. Ransome. 1903. 168 pp., 27 pls.

B 212. Oil fields of the Texas-Louisiana Gulf Coastal Plain, by C. W. Hayes and William Kennedy. 1903. 174 pp., 11 pls. (Out of stock.)

B 213. Contributions to economic geology, 1902; S. F. Emmons, C. W. Hayes, geologists in charge. 1903. $449 \mathrm{FP}$. (Out of stock.)

PP 15. The mineral resources of the Mount Wrangell district, Alaska, by W. C. Mendenhall and F. C. Schrader. 1903.71 pp., 10 pls.

B 218. Coal resources of the Yukon, Alaska, by A. J. Collier. 1903.71 pp., 6 pls.

B 219. The ore deposits of Tonopah, Nevada (preliminary report), by J. E. Spurr. 1903.31 pp., 1 pl. (Out of stock.)

PP 20. A reconnaissance in northern Alaska in 1901, by F. C. Schrader. 1904.139 pp., 16 pls.

PP 21. Geology and ore deposits of the Bisbee quadrangle, Arizona, by F. L. Ransome. 1904.168 pp., 29 pls.

B 223. Gypsum deposits of the United States, by G. I. Adams and others. 1904. 129 pp., 21 pls.

PP 24. Zine and lead deposits of northern Arkansas, by G. I. Adams. 1904. 118 pp., 27 pls.

PP 25. Copper deposits of the Encampment district, Wyoming, by A. C. Spencer. 1904.107 pp., 2 pls.

B 225. Contributions to economic geology, 1903; S. F. Emmons, C. W. Hayes, geologists in charge. 1904. 527 pp., 1 pl. (Out of stock.)

PP 26. Economic resources of the northern Black Hills, by J.D. Irving, with contributions by S. F. Emmons and T: A. Jaggar, jr, 1904, 222 pp., 20 pls.

PP 27. A geological reconnaissance across the Bitterroot Range and Clearwater Mountains in Montana and Idaho, by Waldemar Lindgren. 1904.123 pp., 15 pls.

B 229. Tin deposits of the York region, Alaska, by A. J. Collier. 1904. 61 pp., 7 pls.

B 236. The Porcupine placer district, Alaska, by C. W. Wright. 1904.35 pp., 10 pls.

B 238. Economic geology of the Iola quadrangle, Kansas, by G. I. Adams, Erasmus Haworth, and W. R. Crane. 1904. 83 pp., 11 pls.

B 243. Cement materials and industry of the United Strtes, by E. C. Eckel. 1905.395 pp., 15 pls.

B 246. Zinc and lead deposits of northwestern Illinois, by H. Foster Bain. 1904.56 pp., 5 pls.

B 247. The Fairhaven gold placers of Seward Peninsula, Alaska, by F. H. Moffit. 1905.85 pp., 14 pls.

B 249. Limestones of southeastern Pennsylvania, by F. G. Clapp. 1905.52 pp., 7 pls.

B 250. The petroleum fields of the Pacific coast of Alaska, with an account of the Bering River coal deposits, by G. C. Martin. 1905. 65 pp., 7 pls.

B 251. The gold placers of the Fortymile, Birch Creek, and Fairbanks regions, Alaska, by L. M. Prindle, 1905. 89 pp., 16 pls.

WS 117. The lignite of North Dakota and its relation to irrigation, by F. A. Wilder. $1905 . \quad 59$ pp. 8 pls.

PP 36. The lead, zinc, and fluorspar deposits of western Kentucky, by E. O. Lilrich and W. S. T. Smith. 1905.218 pp., 15 pls.

PP 38. Economic geology of the Bingham mining district, Utah, by J. M. Boutwell, with a chapter on areal geology, by Arthur Keith, and an introduction on general geulogy, by S. F. Emmons. 1905. 413 pp., 49 pls.

PP 41. Geology of the central Copper River region, Alaska, by W: C. Mendenhall. 1905 . 133 pp., 20 pls.

B 254. Report of progress in the geological resurvey of the Cripple Creek district, Colorado, by Waldemar Lindgren and F. L. Ransome. 1904. 36 pp. 
B 255. The fluorspar deposits of southern Illinois, by H. Foster Bain. 1905. 75 pp., 6 pls.

.B 256. Mineral resources of the Elders Ridge quadrangle, Pennsylvania, by R. W. Stone. 1905. $86 \mathrm{pp} ., 12 \mathrm{pls}$.

B 259. Report on progress of investigations of mineral resources of Alaska in 1904, by A. H. Brooks and others. 1905 . $196 \mathrm{pp} ., 3$ pls.

B 260. Contributions to economic geology, 1904; S. F. Emmons and C. W. Hayes, geologists in charge. 1905. 620 pp., 4 pls.

B 261. Preliminary report on the operations of the coal-testing plant of the United States Geological Survey at the Louisiana Purchase Exposition, St. Louis, Mo., 1904; E. W. Parker, J. A. Holmes, and M. R. Campbell, committee in charge. $1905.172 \mathrm{pp.} \mathrm{(Out} \mathrm{of} \mathrm{stock.)}$

B 263. Methods and cost of gravel and placer mining in Alaska, by C. W. Purington. 1905. 273 pp., 42 pls.

PP 42. Geology of the Tonopah mining district, Nevada, by J. E. Spurr. 1905. 295 pp., 24 pls.

PP 43. The copper deposits of the Clifton-Morenei district, Arizona, by Waldemar Lindgren. 1905. 375 pp., $25 \mathrm{pls}$.

B 264. Record of deep-well drilling for 1904, by M. L. Fuller, E. F. Lines, and A. C. Veatch. 1905. $106 \mathrm{pp}$.

B 265. Geology of the Bonlder district, Colorado, by N. M. Fenneman. 1905.101 pp., 5 pls.

B 267. The copper deposits of Missouri, by H. Foster Bain and E. O. Ulrich. $1905.52 \mathrm{pp} ., 1 \mathrm{pl}$.

B 269. Corundum and its occurrence and distribution in the United States (a revised and enlarged (dition of Bulletin No. 180), by J. H. Pratt. 1906.175 pp., 18 pls.

PP 48. Report on the operations of the coal-testing plant of the United States Geological Survey at the Louisiana Purchase Exposition, St. Louis, Mo., 1904; E. W. Parker, J. A. Holmes, M. R. Campbell, committee in charge. 1906. (In 3 parts.) 1492 pp., 13 pls.

B 275. Slate deposits and slate industry of the Innited States, by T. N. Dale, with sections by E. C. Eckel, W. F. Hillebrand, and A. T. Coons. 1906.

PP 49. Geology and mineral resources of part of the Cumberland Gap coal field, Kentucky, by G. H. Ashley and L. C. Glenn, in cooperation with the State Geological Department of Kentucky, C. J. Norwood, curator. 1906.239 pp., 40 pls.

B 277. Mineral resources of Kenai Peninsula, Alaska: Gold fields of the Turnagain Arm region, by F. H. Moffit; Coal fields of the Kachemak Bay region, by R. W. Stone. 1906.

B 278. Geology and coal resources of the Cape Lisburne region, Alaska, by A.J. Collier. 1906.54 pp., 9 pls.

\section{SERIES B, DESCRIPTIVE GEOLOGY.}

B 23. Observations on the junction between the Eastern sandstone and the Keweenaw series on Keweenaw Point, Lake Superior, by R. D. Irving and T. C. Chamberlin. 1885. 124 pp., $17 \mathrm{pls}$. (Out of stock.)

B 33. Notes on geology of northern California, by J. S. Diller. 1886. 23 pp. (Out of stock.)

B 39. The upper beaches and deltas of Glacial Lake Agassiz, by Warren Upham. 1887. 84 pp., 1 pl. (Out of stock.)

B 40. Changes in river courses in Washington Territory due to glaciation, by Bailey Willis. 1887. 10 pp., 4 pls. (Out of stock.)

B 45. The present çondition of knowledge of the geology of Texas, by R. T. Hill. 1887. 94 pp. (Out of stock.)

B 53. The geology of Nantucket, by N. S. Shaler. 1889.55 pp., 10 pls. (Out of stock.)

B 57. A geological reconnaissance in southwestern Kansas, by Robert Hay. 1890. 49 pp., 2 pls. (Out of stock.)

B 58. The glacial boundary in western Pennsylvania, Ohio, Kentucky, Indiana, and Illinois, by G. F. Wright, with introduction by T. C. Chamberlin. 1890.112 pp., 8 pls. (Out of stock.)

B 67. The relations of the traps of the Newark system in the New Jersey region, by N. H. Darton. 1890. $82 \mathrm{pp}$. (Out of stock.)

B 104. Glaciation of the Yellowstone Valley north of the Park, by W. H. Weed. $1893.41 \mathrm{pp} ., 4 \mathrm{pls}$. (Out of stock.)

B 108. A geological reconnaissance in central Washington, by I. C. Russell. 1893. 108 pp., 12 pls. (Out of stock.)

B 119. A geological reconnaissance in northwest Wyoming, by G. H. Eldridge. 1894.72 pp., 4 pls. (Out of stock.)

B 137. The geology of the Fort Riley Military Reservation and vicinity, Kansas, by Robert Hay. 1896. $35 \mathrm{pp} ., 8 \mathrm{pls}$.

B 144. The moraines of the Missouri Cotenu and their attendant deposits, by J. E. Todd. 1896. 71 pp., 21 pls.

B 158. The moraines of southeastern South Dakota and their attendant deposits, by J. E. Todd. 1899. 171 pp., 27 pls.

B 159. The geology of eastern Berkshire County, Massachusetts, by B. K. Emerson. 1899. 139 pp., 9 pls.

B 165. Contributions to the geology of Maine, by H. S. Williams and H. E. Gregory. 1900. $212 \mathrm{pp}$. 14 pls. 
WS 70. Geology and water resources of the Patrick and Goshen Hole quadrangles in eastern Wyoming and western Nebraska, by G. I. Adams. 1902.60 pp., 11 pls.

B 199. Geology and water resources of the Snake River Plains of Idaho, by I. C. Russell. 1902.192 pp., 25 pls.

PP 1. Preliminary report on the Ketchikan mining district, Alaska, with an introductory sketch of the geology of southeastern Alaska, by A. H. Brooks. 1902. 120 pp., 2 pls.

PP 2. Reconnaissance of the northwestern portion of Seward Peninsula, Alaska, by A. J. Collier. 1902. 70 pp., 11 pls.

PP 3. Geology and petrography of Crater Lake National Park, by J. S. Diller and H. B. Patton. 1902. 167 pp., 19 pls.

PP 10. Reconnaissance from Fort Hamlin to Kotzebue Sound, Alaska, by way of Dall, Kanuti, Allen, and Kowak rivers, by W. C. Mendenhall. 1902. 68 pp., 10 pls.

PP 11. Clays of the United States east of the Mississippi River, by Heinrich Ries. $1903.298 \mathrm{pp} ., 9 \mathrm{pls}$.

PP 12. Geology of the Globe copper district, Arizona, by F. L. Ransome. 1903.168 pp., 27 pls.

PP 13. Drainage modifications in southeastern Ohio and adjacent parts of West Virginia and Kentucky, by W. G. Tight. 1903. 111 pp., 17 pls.

B 208. Descriptive geology of Nevada south of the fortieth parallel and adjacent portions of California, by J.E. Spurr. 1908.229 pp., 8 pls.

B 209. Geology of Ascutney Mountain, Vermont, by R. A. Daly. 1903. 122 pp., 7 pls.

WS 78. Preliminary report on artesian basins in southwestern Idaho and southeastern Oregon, by I. C. Russell. 1903. 51 pp., 2 pls.

PP 15. Mineral resources of the Mount Wrangell district, Alaska, by W. C. Mendenhall and F. C. Schrader. 1903. 71 pp., 10 pls.

PP 17. Preliminary report on the geology and water resources of Nebraska west of the one hundred and third meridian, by $\mathrm{N}$. H. Darton. $1903.69 \mathrm{pp} ., 43 \mathrm{pls}$.

B 217. Notes on the geology of southwestern Idaho and southeastern Oregon, by I. C. Russell. 1903. 83 pp., 18 pls. (Out of stock.)

B 219. The ore deposits of Tonopah, Nevada (preliminary report), by J. E. Spurr. $1903.31 \mathrm{pp}, 1 \mathrm{pl}$. (Out of stock.)

PP 20. A reconnaissance in northern Alaska in 1901, by F. C. Schrader. 1904.139 pp., 16 pls.

PP 21. The geology and ore deposits of the Bisbee quadrangle, Arizona, by F. L. Ransome. 1904. $168 \mathrm{pp}$., $29 \mathrm{pls}$.

WS 90. Geology and water resources of part of the lower James River Valley, South Dakota, by J. E. Todd and C. M. Hall. $1904.47 \mathrm{pp}$., 23 pls.

PP 25: The copper deposits of the Encampment district, Wyoming, by A. C. Spencer. 1904.107 pp., 2 pls.

PP 26. Economic resources of northern Black Hills, by J. D. Irving, with chapters by S. F. Emmons and T. A. Jaggar, jr. 1904.222 pp., 20 pls.

PP 27. Geological reconnaissance across the Bitterroot Range and the Clearwater Mountains in Montana and Idaho, by Waldemar Lindgren. $1904.122 \mathrm{pp}, 15 \mathrm{pls}$.

PP 31. Preliminary report on the geology of the Arbuckle and Wichita mountains in Indian Territory and Oklahoma, by J. A. Taff, with an appendix on reported ore deposits in the Wichita Mountains, by H. F. Bain. 1904.97 pp., 8 pls.

B 235. A geological reconnaissance across the Cascade Range near the forty-ninth parallel, by G. $O$. Smith and F. C. Calkins. 1904. 103 pp., 4 pls.

B 236. The Porcupine placer district, Alaska, by C. W. Wright. 1904 . 35 pp., 10 pls.

B 237. Igneous rocks of the Highwood Mountains, Montana, by L. V. Pirsson. 1904. 208 pp., 7 pls.

B 238. Economic geology of the Iola quadrangle, Kansas, by G. I. Adams, Erasmus Haworth, and W. R. Crane. 1904. 83 pp., 1 pl.

PP 32. Geology and underground water resources of the central Great Plains, by N. H. Darton. $1905^{\circ}$. $433 \mathrm{pp} ., 72 \mathrm{pls}$. (Out of stock.)

WS 110. Contributions to hydrology of eastern United States, 1904; M. G. Fuller, geologist in charge. 1905. $211 \mathrm{pp} ., 5 \mathrm{pls}$.

B 242. Geology of the Hudson Valley between the Hoosic and the Kinderhook, by T. Nelson Dale. 1904. 63 pp., 3 pls.

PP 34. The Delavan lobe of the Lake Michigan glacier of the Wisconsin stage of glaciation and associáted phenomena, by W. C. dlden. $1904.106 \mathrm{pp} ., 15 \mathrm{pls}$.

PP 35. Geology of the Perry basin in southeastern Maine, by G. O. Smith and David White. 1905. 107 pp., 6 pls. (Out of stock.)

B 243. Cement materials and industry of the United States, by E. C. Eckel. 1905.395 pp., 15 pls.

B 246. Zine and lead deposits of northwestern Illinois, by H. F. Bain. 1904.56 pp., 5 pls.

B 247. The Fairhaven gold placers of Seward Peninsula, Alaska, by F. H. Moffit. 1905.85 pp., 14 pls.

B 249. Limestones of southwestern Pennsylvania, by F. G. Clapp. 1905. 52 pp., 7 pls.

B 250. The petroleum fields of the Pacific coast of Alaska, with an account of the Bering River coal deposit, by G. C. Martin. 1905. 64 pp., 7 pls.

B 241. The gold placers of the Fortymile, Birch Creek, and Fairbanks regions, Alaska, by L. M. Prindle. 1905. 89 pp., 16 pls. 
WS 118. Geology and water resources of a portion of east-central Washington, by F. C. Calkins. 1905. 96 pp., 4 pls.

B 252. Preliminary report on the geology and water resources of central Oregon, by I. C. Russell. 1905. 138 pp., 24 pls.

PP 36. The lead, zinc, and fluorspar deposits of western Kentucky, by E. O. Ulrich and W.S. Tangicr Smith. 190.7. 218 pp., 15ipls.

PP 38. Economic geology of the Bingham mining district, Utah, by J. M. Bolitwell, with a chapter on areal geology, by it rthur keith, and an introduction on general geology, by S. F. Emmons. 1905. 413 pp., 49 pls.

PP 41. Geology of the central Copper River region, Alaska, by W. C. Mendenhall. 1905. 133 pp., $20 \mathrm{pls}$.

B 254. Report of progress in the geological resurvey of the Cripple Creek district, Colorado, by Waldemar Jindgren and F. L. Runsome. 1904. $36 \mathrm{pp.}$

B 255. The fluorspar deposits of southern Illinois, by H. Foster Bain. 1905.75 pp., 6 pls.

B 256. Mineral resources of the Elders Ridge quadrangle, Pennsylvania, by R. W. Stone. 1905. $86 \mathrm{pp} ., 12 \mathrm{pls}$.

B 257. Geology and paleontology of the Judith River beds, by T. W. Stanton and J. B. Hatcher, with a chapter on fossil plants, by F. H. Knowlton. 1905.174 pp., 19 pls.

PP 42. Geology of the Tonopah mining district, Nevada, by J.'E. Spurr. $1905.295 \mathrm{pp}, 23 \mathrm{pls.}$

WS 123. Geology and underground water conditions of the Jornada del Muerto, New Mexico, by C. R. Keyes. 1905. 42 pp., 9 pls.

WS 136. Underground waters of Salt River Valley, Arizona, by W. T. Lee. 19c5. 194 pp., 24 pls.

PP 43. The copper deposits of the Clifton-Morenci district, Arizona, by Waldemar Lindgren. 1905. 375 pp., 25 pls.

B 265. Geology of the Boulder district, Colorado, by N. M. Fenneman. . 1905. 101 pp., 5 pls.

B 267. The copper deposits of Missouri, by H. F. Bain and E. O. Ulrich. $1905.52 \mathrm{pp}, 1 \mathrm{pl}$.

PP 44. Underground water resources of Long Island, New York, by A. C. Veatch, C. S. Slichter, Isaiah Bowman, W. O. Crosby, and R. E. Horton. 1906. 394 pp., 34 pls.

WS 148. Geology and water resources of Oklahoma, by C. N. Gou\}d. 1905.178 pp., 22 pls.

B 270. The configuration of the rock floor of Greater New York, by W. H. Hobbs. 1905.96 pp., 5 pls.

B 272. Taconic physiography, by T. N. Dale. 1905. 52 pp., 14 pls. (Out of stock.)

PP 45. The geography and geology of Alaska, a summary of existing knowledge, by A. H. Brooks, with a section on climate, by Cleveland $\mathrm{Abbe}, \mathrm{jr}$., and a topographic map and description thereof, by R. U. Goode. 1906.327 pp., 34 pls.

B 273. The drumlins of southeastern Wisconsin (preliminary paper), by W. C. Alden. 1905. 46 pp., 9 pls.

PP 46. Geology and underground water resources of northern Louisiana and southern Arkansas, by A. C. Veatch, 1906.

PP 49. Geology and mineral resources of part of the Cumberland Gap coal field, Kentucky, by G. H. Ashley and L. C. Glenn, in cooperation with the State Geological Department of Kentucky, C. J. Norwood, curator. 1906.239 pp., $40 \mathrm{pls}$.

PP 50. The Montana lobe of the Keewatin ice sheet, by F. H. H. Calhoun. 1906.

B 277. Mineral resources of Kenai Peninsula, Alaska: Gold fields of the Turnagain Arm region, by F. H. Moffit; Coal fields of the Kachemak Bay region, by R. W. Stone. 1906.

WS 154. Geology and water resources of the eastern portion of the Pauhandle of Texas, by C. N. Gould. 1906.

B 278. Geology and coal resourees of the Cape Lisburne Fegion, Alaska, by A. J. Collier. 1906.54 pp., 9 pls.

Correspondence should be addressed to

The Director,

United States Geological Survey, W Ashington, D. C.

MaY, 1906. 


\section{GEOLOGICAL SURVEY PUBLICATIONS ON ALASKA.}

1891.

Russell, I. C. Account of an expedition to the Yukon Valley in 1889. In Eleventh Ann. Rept., pt. 1, 1891, pp. 57-58. Extract from Professor Russell's complete report in Bull. Geol. Soc. America, vol. 1, 1890, pp. 99-162. (Out of stock.)

Account of an expedition to the vicinity of Mount St. Elias in 1890. In Twelfth Ann. Rept., pt. 1, 1891, pp. 59-61. A full report of this expedition was published in Nat. Geng. Mag., vol. 3, 1892, pp. 53-203. (Out of stock.)

1892.

Dall, W. H., and Harris, G. D. Summary of knowledge of Neocene geology of Alaska. In correlation Päpers-Neocene: Bull. No. 84, 1892, pp. 232-268.

HAYES, C. W. Account of expedition through the Yukon district. In Thirteenth Ann. Rept., pt. 1, 1892, pp. 91-94. A complete report was published in Nat. Geog. Mag., vol. 4, 1892, pp. 117-162. (Out of stock.)

1893.

Russelt, I. C. Second expedition to Mount St. Elias in 1891 . In Thirteenth Ann. Rept., pt. 2, 1893, pp. 1-91. (Out of stock.)

1896.

DalL, W. H. Report on .coal and lignite of Alaska. In Seventeenth Ann. Rept., pt. 1, 1896, pp. 763-906. (Out of stock.)

ReID, H. F. Glacier Bay and its glaciers. In Sixteenth Ann. Rept., pt. 1, 1896, pp. 415-461. (Out of stock.)

W ALcotr, C. D., Director. Account of an investigation of the gold and coal deposits of southern Alaska. In Seventeenth Ann. Rept., pt. 1, 1896, pp. 56-59. (Out of stock.)

1897.

W ALcotT, C. D., Director. Account of a reconnaissance of the gold district of the Yukon region. In Eighteenth Ann. Rept., pt. 1, 1897, pp. 52-54. (Out of stock.)

1898.

Becker, G. F. Reconnaissance of the gold fields of southern Alaska, with some notes on general geology. In Eighteenth Ann. Rept., pt. 3, 1898, pp. 1-86. (Out of stock.)

Spurr, J. E., and Goodrich, H. B. Geology of the Yukon gold district, Alaska, by Josiah Ed ward Spurr; with an introductory chapter on the history and condition of the district to 1897, by Harold Beach Goodrich. In Fighteenth Ann. Rept., pt. 3, 1898, pp. 87-392. (Out of stock.)

WALCort, C. D., Director. Account of operations in Alaska in 1898 . In Nineteenth Ann. Rept., pt. 2, 1898, pp. 20, 53, 116-117. (Out of stock:)

Map of Alaska, showing known gold-bearing rocks, with descriptive text containing sketches of the geography, geology, and gold deposits and routes to the gold fields. Prepared in accordance with Public Resolution No. 3 of the Fifty-fifth Congress, second session, approved January 20, 1898. Printed in the engraving and printing division of the United States Geological Survey, Washington, D. C., 1898. 44 pp., 1 map. A special publication. The data were brought together by S. F. Emmons, aided by W. H. Dall and F. C. Schrader. (Out of stock.)

1899.

WALcotT, C. D., Director. Account of operations in Alaska in 1899. In Twentieth Ann. Rept., pt. 1, 1899, pp. 12, 52-53, 97, 126-134. (Out of stock.)

Maps and descriptions of routes of exploration in Alaska in 1898, with general information concerning the Territory. (Ten maps in accompanying envelope.) Prepared in accordance with Public Resolution No. 25 of the Fifty-fifth Congress, third session, approved March 1, 1899. Printed in the engraving and printing division of the United States Geological Survey, Washington, D. C., $1899.138 \mathrm{pp}$., $10 \mathrm{maps}$ in accompanying envelope. A special publication. Contributors: G. H. Eldridge, Robert Muldrow, J. E. Spurr, W. S. Post, W. C. Mendenhall, F. C. Schrader, W. J..Peters, A. H. Brooks, and E. C. Barnard. (Out of stock.) 
1900.

BAKER, MARCus. Alaskan geographic names. In Twenty-first Ann. Rept., pt. 2, 1900 , pp. $487-509$. (Out of stock.)

Brooks, A. H. A reconnaissance from Pyramid Harbor to Eagle City, Alaska, including a description of the copper deposits of the upper White and Tanana rivers. In Twenty-first Ann. Rept., pt. 2, 1900, pp. 331-391. (Out of stock.)

A reconnaissance in the Tanana and White River basins, Alaska, in 1898. In Twentieth Ann. Rept., pt. 7, 1900, pp. 425-494. (Out of stock.)

EldRIDGE, G. H. A reconnaissance in the Sushitna basin and adjacent territory, Alaska, in 1898. In Twentieth Ann. Rept., pt. 7, 1900, pp. 1-29.

Gannetr, Henry. Altitudes in Alaska. Bull. No. 169, 1900, $13 \mathrm{pp}$.

Mendenhal.L, W. C. A reconnaissance from Resurrection Bay to the Tanana River, Alaska, in 1898. In Twentieth Ann. Rept., pt. 7, 1900, pp. 265-340.

Rohn, Oscars. A reconnaissance of the Chitina River and the Skolai Mountains, A laska. In Twenty-first Ann. Rept., pt. 2,1900,pp. 303-340. (Out of stock.)

Schrader, F. C. A reconnaissance of a part of Prince William Sound and the Copper River district, Alaska, in 1898. In Twentieth Ann. Rept., pt. 7, 1900, pp. 341-423. (Out of stock.)

Preliminary report on a reconnaissance along the Chandlar and Koyukuk rivers, Alaska, in 1899 . In Twenty-first Ann. Rept., pt. 2, 1900, pp. 441486. (Out of stock.)

and Brooks, A. H. Preliminary report on the Cape Nome gold region, Alaska, with maps and illustrations. Washington, Government Printing Office, $1900.56 \mathrm{pp} ., 3$ maps, and 19 pls. A special publication.

Sirurr, J. E. A reconnaissance in southwestern Alaska in 1898. In Twentieth Ann. Rept., pt. 7, 1900, pp. 31-264.

WALcotr, C. D., Director. Account of operations in Alaska in 1900. In Twentyfirst Ann. Rept., pt. 1, 1900, pp. 17-18, 86, 145-149. (Out of stock.)

1901.

Brooks, A. H. An occurrence of stream tin in the York region, Alaska. In Mineral Resources of the U. S. for 1900, 1901, pp. 267-271. Published also as a separate, Washington, Government Printing Office, 1901, cover and pp. 1-5. (Out of stock.)

The coal resources of Alaska. In Twenty-second Ann. Rept., pt. 3, 1901, pp. 515-571. (Out of stock.)

Richardson, G. B., and Collisr, A. J. A reconnaissance of the Cape Nome and adjacent gold fields of Seward Peninsula, Alaska, in 1900. In a special publication entitled "Reconnaissances in the Cape Nome and Norton Bay regions, Alaska, in 1900," Washington, Government Printing Office, 1901, pp. $1-180$.

MendenhalL, W. C. A reconnaissance in the Norton Bay region, Alaska, in 1900. In a special publication entitled "Reconnaissances in the Cape Nome and Norton Bay regions, Alaska, in 1900," Washington, Government Printing Office, 1901, pp. 181-218.

SChrader, F. C., and Spencer, A. G. The geology and mineral resources of a portion of the Copper River district, Alaska. A special publication, Washington, Government Printing Office, 1901, pp. 1-94.

WALcotT, C. D., Director. Account of operations in Alaska in 1901. In Twentysecond Ann. Rept., pt. 1, 1901, pp. 35, 95-99, 144, 166-170. (Out of stock.)

1902.

Brooks, A. H. Preliminary report on the Ketchikan mining district, Alaska, with an introductory sketch of the geology of southeastern Alaska. Prof. Paper No. 1, 1902, pp. 1-120.

Collier, A.J. A reconnaissance of the northwestern portion of Seward Peninsula, Alaska. Prof. Paper No. 2, 1902, pp. 1-70.

Mendenfalis, W. C. A reconnaissance from Fort Hamlin to Kotzebue Sound, Alaska, by way of Dall, Kanuti, Allen, and Kowak rivers. Prof. Paper No. 10,1902 , pp. 1-68.

W AlcorT, C. D., Director. Account of operations in Alaska in 1902. In Twentythird Ann. Rept., 1902, pp. 20, 21, 57, 71-82, 161.

1903.

Baker, Marcus. Geographic dictionary of Alaska. Bull. No. 187, 1902, pp. 1-446. (Out of stock.)

Brook', A. H. Placer gold mining in Alaska in 1902. In Bull. No. 213, 1903, pp. 4I-48. (Out of stock.) 
Broors, A. H. Stream tin in Alaska. In Bull: No. 213, 1903, pp. 92-93. (Out of stock.) ColLier, A. J. Coal resources of the Yukon basin, Alaska. In Bull. No. 213, 1903, pp. 276-283. (Out of stock.)

The coal resources of the Yukon, Alaska. Bull. No. 218, 1903, pp. 1-71.

- The Glenn Creek gold mining district, Alaska.' In Bull. No. 213, 1903, pp. 49-56. (Out of stock.)

MendenhalL, W. C. The Chistochina gold field, Alaska: In Bull. No. 213; 1903, pp. 71-75. (Out of stock.)

and SchraDER, F. C. Copper deposits of Mount Wrangell region, Alaska. In Bull. No. 213, 1903, pp. 141-148. (Out of stock.)

The mineral resources of the Mount Wrangell district, Alaska. Prof. Paper No. 15,1903 , pp. 1-71.

WALcotr, C. D., Director. Account of operations in Alaska in 1903. In Twentyfourth Ann. Rept., 1903, pp. 78-107, 167, 256.

1904.

Brooks, A. H. Placer gold mining in Alaska in 1903. In Bull. No. 225, 1904, pp. 43-59. (Out of stock.)

Coldier, A. J. Tin deposits of the York region, Alaska. In Bull. No. 225, 1904, pp. 154-167. (Out of stock.)

- Tin deposits of the York region, Alaska. Bull. No. 229.

Martin, G. C. Petroleum fields of Alaska and the Bering River coal field. In Bull. No. 225,1904, pp. $365-382$. (Out of stock.)

Morrit, F. H. The Kotzebue placer gold field of Seward Peninsula, Alaska. In Bull. No. 225, 1904, pp. 74-80. (Out of stock.)

Prindie, L. M. Gold placers of the Fairbanks- district, Alaska. In Bull. No. 225, 1904, pp. 64-73. (Ont of stock.)

Schrader, F. C., and Peters, W. J. A reconnaissance in northern Alaska, across the Rocky Mountains, along the Koyukuk, John, Anaktuvuk, and Colville rivers, and the Arctic coast to Cape Lisburne, in 1901. Prof. Paper No. 20,1904 , pp. 1-139.

Spencer, A. C. The Juneau gold belt, Alaska. In Bull. No. 225, 1904, pp. 28-42. (Out of stock.)

WALCort, C. D., Director. Account of operations in Alaska in 1903-4. In Twentyfifth Ann. Rept. U. S. Geol. Survey, 1904, pp. 68-85, 346, 348, 352, 354.

Wright, C. W. The Porcupine placer mining district, Alaska. In Bull. No. 225, 1904, pp. 60-63. (Out of stock.)

The Porcupine placer district, Alaska. Bull. No. 236, 1904, pp. 1-35.

1905.

Brooks, A. H. Administrative report. In Report on progress of investigations of mineral resources of Alaska in 1904: Bull. U. S. Geol. Survey No. 259, 1905, pp. 13-17.

Placer mining in Alaska in 1904. In Bull. No. 259, 1905, pp. 18-31.

Collier, A. J. Coal fields of the Cape Lisburne region. In Bull. No. 259, 1905, pp. 172-185.

Gold mine on Unalaska Island. In Bull. No. 259, 1905, pp. 102-103.

- Recent developments of Alaskan tin deposits. In Bull. No. 259, 1905, pp. 120-127.

Martin, G. C. Bering River coal field. In Bull. No. 259, 1905, pp. 140-150.

Cape Yaktag placers. In Bull. No. 259, 1905, pp. 88-89. - Gold deposits of the Shumagin Islands. In Bull. No. 259, 1905, pp. 100-101.

The petroleum fields of the Pacific coast of Alaska, with an account of the Bering River coal deposits. Bull. No. 250, 1905, pp. 1-64.

Mendentrale, $W$. C. Geology of the central Copper River region, Alaska. Prof. Paper No. 41, 1905, pp. 1-133.

Morfit, F. H. Gold placers of Turnagain Arm, Cook Inlet. In Bull. No. 259, 1905, pp. 90-99.

The Fairhaven gold placers of Seward Peninsula. Bull. No. 247, pp. 1-85.

Prinde, L. M. The gold placers of the Fortymile, Birch Creek, and Fairbanks regions. Bull. No. 251, 1905, pp. 1-89.

and Hess, F. L. Rampart placer region. In Bull. No. 259, 1905, pp. 104119.

Purington, C. W. Methods and costs of gravel and placer mining in Alaska. Bull. No. 263, 1905, pp. 1-362. Also in Bull. No. 259, 1905, pp. 32-46.

Spencer, A. C. The Treadwell ore deposits. In Bull. No. 259, 1905, pp. 69-87.

SToNe, R. W. Coal resources of south.western Alaska. In Bull. No. 259, 1905, pp. 151-171. 
WalcotT, C. D., Director. Account of operations in Alaska in 1905. In Twentysixth Ann. Rept., $190 \overline{5}$, pp. $73-80$.

WRIGHT, F. E. and C. W. Economic developments in southeastern Alaska. In Bull. No. 259, 1905, pp. 47-68.

1906.

Brooks, A. H. The geography and geology of Alaska, a summary of existing knowledge, with a section on climate, by Cleveland Abbe, $\mathrm{jr}$., and a topographic: map and description thereof, by R. U. Goode. Prof. Paper No. 45, 1906, pp. 1-327.

Collier, A.J. Geology and coal resources of Cape Lisburne region, Alaska. Bull. No. 278,1906 , pp. $1-54$

Moffit, F. H., and Stone, R. W. Mineral resources of the Kenai Peninsula; Gold fields of the Turnagain A Arm region, by F. H. Moffit; Coal fields of the Kachemak Bay region, by R. W. Stone. Bull. No. 277.

Prinde, L. M., and Hess, F. L. The Rampart gold placer region, Alaska. Bull. No. 280,1906 , pp. 1-54.

\section{Papers on Alaska in Preparation.}

Bronks, A. H. An exploration in the Mount McKinley region.

and others. Report on progress of investigation of mineral resources of Alaska in 1905. Bull. No. 284.

Collier, A. J., Hess, F. L., and Brooks, A. H. The gold placers of a part of the Seward Peninsula, Alaska.

Martin, G. C. Geology of the Controller Bay coal field, Alaska. Preliminary report on the Matanuska coal field, Alaska. Bull, No. 289.

Prinder, L. M. Description of the Circle quadrangle, Yukon-Tanana region, Alaska.

SPENCER, A. C., and W RIGHT, C. W'. The Juneau gold belt, Alaska; by A. C. Spencer, and $A$ reconnaissance of Admiralty Island, Alaska, by C. W. Wright. Bull. No. 287.

WRIGHT, F. F. and C. W. Mineral resources of the Wrangell and Ketchikan mining districts, Alaska.

\section{Topographic Maps of Alaska.}

The following maps are for sale at 5 cents a copy, or $\$ 3$ per hundred:

Fortymile quandrangle; scale, 1:250000. E. C. Barnard.

Grand Central Special, Seward Peninsula; scale, 1:62500. T. G. Gerdine.

Juneau Special quadrangle; scale, 1:62500. W. J. Peters.

Nome Special, Seward Peninsula; scale, 1:62500. T. G. Gerdine.

The following maps are included as illustrations of published reports, but have not been issued separately. They can be obtained only by securing the report.

Alaska, topographic map of; scale, 1:2500000. Preliminary edition. Contained in "The geography and geology of Alaska, a summary of existing knowledge, etc." Prof. Paper No. 45 . R. U. Goode.

Cape Nome and adjacent gold fields; scale, 1:250000. Contained in a special publication of the United States Geological Survey, entitled "Reconnaissances in the Cape Nome and Norton Bay regions, Alaska," 1900. Washington. Government Printing Office, 1901. E. C. Barnard.

Chitina and lower Copper River region; scale, 1:250000. Contained in a special publication of the United States Geological Survey, entitled "The geology and mineral resources of a portion of the Copper River. district, Alaska." Washington. Government Printing Office, 1901." T. G. Gerdine and D. C. Witherspoon.

Cook Inlet, head of, to the Tanana via Matanuska and Delta rivers, also part of Kenai Peninsula; scale, 1:625000. Contrined in "A reconnaissance from Resurrection Bay to Tanana River, Alaska, in 1898." Twentieth Ann. Rept., pt. 7, 1900 , pp. 265-340. W. C. Mendenhall.

Cook Inlet, region from head of, to Kuskokwim River and down the Kuskokwim to Bering Sea, Bristol Bay, and a part of Alaska Peninsula; scale, 1:625000. Published in sections in "A reconnaissance in southwestern Alaska, in 1898." Twentieth Ann. Rept., pt. 7, 1900, pp. 31-264. W. S. Post.

Cook Inlet placer fields; scale 1:250000. Contained in "Mineral Resources of Kenai Peninsula, Alaska." Bull. No. 277. E. G. Hamilton.

Copper and upper Chistochina rivers; scale, 1:250000. Contained in "Geology of the central Copper River region, Alaska." Prof. Paper No. 41. T. G. Gerdine.

Copper, Nabesna, and Chisana rivers, headwaters of; scale, $1: 250000$. Contained in "Geology of the central Copper River region, Alaska:" Prof. Paper No. 41. D. C. Witherspoon. 
Copper River region; scale, 1:376000. Contained in "A reconnaissance of a part of Prince William Sound and the Copper River district, Alaska, in 1898." Twentieth Ann. Rept., pt. 7, 1900, pp. 341-423. P. G. Lowe, Emil Mahlo, and F. C. Schrader. (Out of stock.)

Fairbanks and Birch Creek districts, reconnaissance maps of; scale, 1:250000. Contained in "The gold placers of the Fortymide, Birch Creek, and Fairbanks regions." Bull. No. 251, 1905. T. G. Gerdine.

Fort Yukon to Kotzebue Sound, reconnaissance map of; scale, 1:625000. Contained in "Reconnaissance from Fort Hamlin to Kotzebue Sound, Alaska, by way of Dall, Kanuti, Allen, and Kowak rivers." Prof. Paper No. 10, 1902. D. L. Reaburn.

Koyukuk River to mouth of Colville River, including John River; scale, 1:625000. Contained in "A reconnaissance in northern Alaska across the Rocky Mountains, along Koyukuk, John, Anaktuvuk, and Colville rivers, and the Aretic coast to Cape lisburne, in 1901." Prof. Paper No. 20. W. J. Peters.

Koyukuk and Chandlar rivers, portions of; scale, 1:625000. Contained in "Preliminary report of a reconnaissance along the Chandlar and Koyukuk rivers, Alaska, in 1899." Twenty-first Ann. Rept., pt. 2, 1900. T. G. Gerdine.

Lynn canal, routes from, via headwaters of White and Tanana rivers to Eagle City; scale, 1:625000. Contained in "A reconnaissance from Pyramid Harbor to Eagle City, Alaska." Twenty-first Ann. Rept., pt. 2, 1900, pp. 331-391. W. J. Peters.

Mount McKinley region; scale, 1:625000. Contained in "The geography and geology of Alaska, a summary of existing knowledge, etc." Prof. Paper No. 45. D. L. Reaburn.

Norton Bay region; scale, 1:625000. Contained in a special publication of the United States Geological Survey, entitled " Reconnaissances in the.Cape Nome and Norton Bay regions, Alaska, in 1900." Washington. Government Printing Office, 1901. W. J. Peters.

Porcupine placer region; scale, 1 inch $=3 \frac{1}{2}$ miles. Contained in "The Porcupine placer district, Alaska." Bull. No. 236. C. W. Wright.

Prince William Sound, sketch map of; scale 1:376000. Contained in a special pulslication of the United States Geological Survey, entitled "The geology and mineral resources of a portion of the Copper River district, Alaska." Washington. Government Printing Office, 1901. Emil Mahlo and F. C. Schrader.

Seward Peninsula, northeastern portion of, topographic reconnaissance of; scale; $1: 250000$. Contained in "The Fairhaven gold placers, Seward Peninsula, Alaska." Bull. No. 247, 1905. D. C. Witherspoon.

Seward Peninsula, northwestern part of; scale, 1:250000. Contained in "A reconnaissance of the northwestern portion of Seward Peninsula, Alaska." Prof. Paper No. 2, 1902. T. G. Gerdine.

Sushitna River and adjacent territory; scale, 1:625000. Contained in "A reconnaissance in the Sushitna basin and adjacent territory, Alaska, in 1898." Twentieth Ann. Rept., pt. 7, 1900, pp. 1-29. Robert Muldrow.

Tanana and White rivers, portions of; scale, 1:625000. Contained in "A reconnaissance in the Tanana and White River basins, Alaska, in 1898." Twentieth Ann. Rept., pt. 7, 1900, pp. 425-494. W. J. Peters.

York region; scale, 1:250000. Contained in "The tin deposits of the York region, Alaska." Bull. No. 229. T. G. Gerdine.

York and Kugruk regions, sketch maps of. Contained in a special publication of the United States Geological Survey, entitled "Reconnaissances in Cape Nome and Norton Bay regions, Alaska, in 1900." Washington. Government Printing Office, 1901. A. H. Brooks.

Yukon-Tanana region, reconnaissance map of; scale, 1:625000. Contained in "The gold placers of the Fortymile, Birch Creek, and Fairbanks regions, Alaska." Bull. No. 251. T. G. Gerdine.

\section{Topographic Maps of Alaska in Preparation.}

Casadepaga Special, Seward Peninsula; scale, 1:62500. T. G. Gerdine.

Circle quadrangle, Yukon-Tanana region; scale, 1:250000. D. C. Witherspoon.

Controller Bay region, special map of; scale, 1:62500. E. G. Hamilton.

Fairbanks placer district; scale, 1:250000. D. C. Witherspoon.

Solomon Special, Seward Peninsula; scale, 1:62500. T. G. Gerdine. 

